Nuno Bandarrinha Brandão

Modelagem da evolução das propriedades mecânicas da pasta de cimento em poços do pré sal

Dissertação de Mestrado

Dissertação apresentada ao programa de Pós-Graduação em Engenharia Civil do Departamento de Engenharia Civil da PUC-Rio como requisito parcial para obtenção do título de Mestre em Engenharia Civil.

Orientadora: Profa. Deane de Mesquita Roehl Co-orientador: Prof. Flávio de Andrade Silva

Rio de Janeiro

Março de 2016 


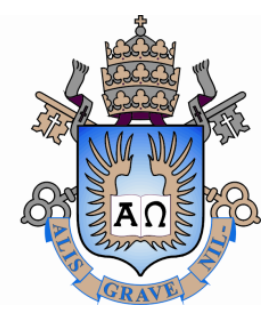

Nuno Bandarrinha Brandão

\section{Modelagem da evolução das propriedades mecânicas da pasta de cimento em poços do pré sal}

Dissertação apresentada como requisito parcial para obtenção do título de Mestre pelo Programa de Pós-Graduação em Engenharia Civil do Departamento de Engenharia Civil do Centro Técnico Científico da PUC-Rio. Aprovada pela Comissão Examinadora abaixo assinada.

Profa. Deane de Mesquita Roehl

Orientadora

Departamento de Engenharia Civil - PUC-Rio

Prof. Flávio de Andrade Silva

Co-orientador

Departamento de Engenharia Civil - PUC-Rio

Prof. Raul Rosas e Silva

Departamento de Engenharia Civil - PUC-Rio

Prof. Eduardo de Moraes Rego Fairbairn

Departamento de Engenharia Civil - UFRJ

Enga. Fernanda Lins Gonçalves Pereira

Tecgraf - PUC-Rio

Prof. Márcio da Silveira Carvalho

Coordenador Setorial do Centro

Técnico Científico - PUC-Rio

Rio de Janeiro, 24 de Março de 2016 
Todos os direitos reservados. É proibida a reprodução total ou parcial do trabalho sem autorização da universidade, do autor e do orientador.

\section{Nuno Bandarrinha Brandão}

Graduou-se em Engenharia Civil pela Universidade de Lisboa (Instituto Superior Técnico) - Portugal, em 2011. Em 2013 terminou o mestrado em Engenharia Estrutural na Universidade de Lisboa (Instituto Superior Técnico). Em 2014 ingressou no curso de Mestrado em Engenharia Civil da Pontifícia Universidade Católica do Rio de Janeiro, na área de Estruturas, onde vem desenvolvendo investigações relacionadas com a Cimentação de Poços de Petróleo.

Ficha Catalográfica

Brandão, Nuno Bandarrinha

Modelagem da evolução das propriedades mecânicas da pasta de cimento em poços do pré sal / Nuno Bandarrinha Brandão; orientadora: Deane de Mesquita Roehl; co-orientador: Flávio de Andrade Silva - 2016.

94 f. : il. color. ; 29,7 cm.

Dissertação (Mestrado) - Pontifícia Universidade Católica de Rio de Janeiro, Departamento de Engenharia Civil, 2016.

Inclui bibliografia

1. Engenharia Civil - Teses. 2. Modelagem numérica. 3. Modelo constitutivo. 4. Pasta de cimento. 5. Cimentação de poços. I. Roehl, Deane de Mesquita. II. Silva, Flávio de Andrade. III. Pontifícia Universidade Católica do Rio de Janeiro. Departamento de Engenharia Civil. IV. Título. 


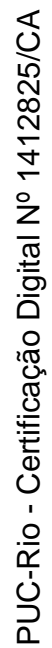

À minha avó Ana Carolina Ferreira Bandarrinha 


\section{Resumo}

Brandão, Nuno Bandarrinha; Roehl, Deane de Mesquita; Silva, Flávio de Andrade. Modelagem da evolução das propriedades mecânicas da pasta de cimento em poços do pré sal. Rio de Janeiro, 2016. 94p. Dissertação de Mestrado - Departamento de Engenharia Civil, Pontifícia Universidade Católica do Rio de Janeiro.

Este estudo tem como objetivo avaliar a influência do desenvolvimento das propriedades mecânicas da pasta de cimento na integridade do poço de petróleo. Um modelo numérico foi desenvolvido para simular as diferentes fases de construção de poços, tais como perfuração, ação da fluência, reconstrução do revestimento e a hidratação do cimento. O comportamento da fluência do sal foi modelado através uma metodologia que combina o Duplo Mecanismo e a Lei da Potência. Duas fases foram consideradas para a pasta de cimento. Em primeiro lugar, a pasta de cimento foi idealizada como um fluido com um campo de tensão hidrostática. Durante as primeiras cinco horas após a cimentação, uma diminuição do campo de tensão hidrostática foi utilizada a fim de simular a retração autógena e a perda de água no processo. Quando a pasta de cimento foi considerada como elástico com um módulo de rigidez crescente ao longo do tempo quando solidificada. Na mudança de fase do fluido para sólido, um cuidado especial foi dado aos elementos que representam a pasta de cimento hidratada a fim de evitar a sobreposição de malhas. A nova lei de fluência do sal apresentou resultados precisos quando comparado aos valores obtidos em campo e a outros dados encontrados na literatura. No processo de hidratação, a redução das dimensões anulares foi observada. A taxa de deformação diminuiu com o aumento do módulo de rigidez da pasta de cimento. Mais importante ainda, esta deformação foi insignificante quando comparada com as dimensões do poço. Assim, a solidificação do cimento pode ser desconsiderada em simulações expeditas.

\section{Palavras-chave}

Modelagem numérica; modelo constitutivo; pasta de cimento; cimentação de poços 


\section{Abstract}

Brandão, Nuno Bandarrinha; Roehl, Deane de Mesquita (Advisor); Silva, Flávio de Andrade (Co-Advisor). Modelling of the evolution of the mechanical properties of the cement paste in pre salt wells. Rio de Janeiro, 2016. 94p. MSc. Dissertation - Departamento de Engenharia Civil, Pontifícia Universidade Católica do Rio de Janeiro.

The quality of the cement sheath plays a crucial role in the integrity of the oil well. This study aims at assessing the influence of cement hardening on deformations and stresses to which the sheath is submitted. A numerical model was developed to simulate the different stages of well construction such as drilling, creep action, casing reconstruction and - the focus herein - cement hardening. The salt creep behavior was modeled through a new methodology that combines the Double Mechanism with the Power Law. Two stages were considered for the cement. First, the cement was idealized as a fluid with a hydrostatic stress field. During the first five hours after cementation, a decrease in the hydrostatic stress field was employed in order to simulate the chemical shrinkage and loss of water in the hardening process. When hardened, the cement was considered to behave elastically with an increasing stiffness modulus over time. In the phase change from fluid to solid, special care was given to fitting the cement finite element mesh to the annulus, avoiding mesh overlapping. The new salt creep law showed accurate results when compared to field and other creep data. In the hardening process, the annular dimension reduction was expected and noticed. The deformation rate decreased with the increasing cement stiffness modulus. Most importantly, this deformation was negligible when compared with the dimensions of the well. Moreover, for practical and quick simulations, the hardening step can be avoided.

\section{Keywords}

Numeric analysis; constitutive models; primary cementing; cementing in oil wells 


\section{Sumário}

1 Introdução 14

1.1. Objetivos da pesquisa 16

1.2. Estrutura da dissertação 16

2 Revisão da literatura $\quad 18$

2.1. Composição química do cimento 19

2.2. Aplicação da pasta cimentícia 22

2.3. Causas de fissuração/perda de ligação e consequências 24

2.3.1. Curto prazo 25

2.3.2. Longo prazo 35

2.4. Considerações finais 41

3 Modelos constitutivos e validação 42

3.1. Aço 42

3.2. Sal 42

3.2.1. Lei de Potência 44

3.2.2. Lei de Duplo Mecanismo 44

3.2.3. Formulação Híbrida 45

3.3. A pasta de cimento $\quad 47$

3.3.1. A pasta de cimento no estado líquido 48

3.3.2. Metodologia para simular os efeitos mecânicos da solidificação do cimento 48

3.3.3. Modelos constitutivos elastoplásticos para simulação da pasta de cimento

4 Processo de construção do poço $\quad 59$

4.1. Estado plano de deformação vs modelo 3D 60

4.2. Automatização da malha 60

4.3. Estudo de caso $1 \quad 62$

4.3.1. Dados geométricos e magnitudes 63 
4.3.2. Geostático

4.3.3. Escavação e reconstrução do revestimento metálico 65

4.3.4. Ação da fluência 65

4.4. Estudo de caso 2

4.4.1. Geostático 72

4.4.2. Escavação e ação da fluência do sal 72

4.4.3. Reconstrução do aço e bombeamento da pasta de cimento $\quad 74$

4.4.4. Pega da pasta cimentícia 76

5 Conclusões e sugestões 85

5.1. Conclusões 85

5.2. Sugestões 88

$\begin{array}{ll}\text { Referências bibliográficas } & 89\end{array}$ 


\section{Lista de figuras}

Figura 2.1 - Períodos para os quais os constituintes do clínquer reagem.

Figura 2.2 - Resistência de cada constituinte do cimento e velocidade de reação

Figura 2.3 - Fases de reconstrução do poço desde a reconstrução do revestimento até ao cimento no anular

Figura 2.4 - Posição dos dispositivos que medem temperatura e pressão no interior do anular e evolução da pressão hidrostática no anular para o dispositivo 1 e 2 na cimentação do poço Fonte: Cooke et al. (1984)

Figura 2.5 - a) canal de gás b) severo canal de gás c) Microannulus migração de gás Fonte: Martins et al. (1997)

Figura 2.6 - Evolução da pressão e resistência do cimento na cura Fonte: Li et al. (2016)

Figura 2.7 - Pressão hidrostática e temperatura em diferentes cotas

Figura 2.8 - Esquema da retração externa (ou autógena), interna e química. $\mathrm{C}=$ Cimento desidratado, $\mathrm{W}=$ Água, $\mathrm{H}_{\mathrm{y}}=$ Produto hidratado e $V=$ vazios gerados pela hidratação Fonte: Japan (1999) apud Holt (2001)

Figura 2.9 - a) Evolução da retração externa em função do grau de hidratação Fonte: Acker (1988) apud Holt (2001)

Figura 2.10 - Círculos de Mohr e envoltória de ruptura da pasta com 7 dias de cura a $60^{\circ} \mathrm{C}$ Fonte: Ramos (2015)

Figura 2.11 - Círculos de Mohr e envoltória de ruptura da pasta com $0,25,0,58,1,3,7,14$ e 28 dias para ensaios à compressão com corpos de prova curados a $60^{\circ} \mathrm{C}$

Figura 2.12 - Círculos de Mohr e envoltória de ruptura da pasta com $0,25,0,58,1,3,7,14$ e 28 dias para ensaios não confinados com corpos de prova curados a $60^{\circ} \mathrm{C}$ 
Figura 2.13 - a) fissuração circunferencial b) fissuração axial c) ruptura por cisalhamento d) esmagamento do cimento e) descolamento do sal-cimento f) descolamento do cimento-aço 36 Figura 2.14 - Gráfico carga-deslocamento para o cimento1 Fonte: Ravi et al. (2006)

Figura 2.15 - Gráfico carga-deslocamento para o cimento3 Fonte: Ravi et al. (2006)

Figura 3.1 - Estágios da fluência

Figura 3.2 - Esquematização do modelo numérico em relação ao modelo experimental Fonte: Firme (2013)

Figura 3.3 - Esquematização do ensaio triaxial Fonte: Firme (2013)

Figura 3.4 - Comparativo entre as várias formulações de fluência e o ensaio experimental

Figura 3.5 - a) tempo [0h;1h] - tensão inicial hidrostática e módulo de elasticidade unitário b) tempo [1h;1,6h] - liberação da restrição em $\mathrm{x}$ do nó 2 e 3 e aplicação de carga de magnitude $0.5 \mathrm{~Pa}$ na face correspondente c) tempo [1,6h;2,2h] - mudança de material de $E_{1}$ para $\mathrm{E}_{2}$

Figura 3.6 - Tensão medida num ponto de Gauss e deslocamento x do nó 2 para a análise com mudança de estado de tensão de acordo com as propriedades mecânicas

Figura 3.7 - Tensão medida num ponto de Gauss e deslocamento x do nó 2 para a análise

Figura 3.8 - Comparação dos quatro D-P e do M-C plano desviatório Fonte: Jiand \& Xie (2011)

Figura 3.9 - Meridiano de Compressão, Cortante e Tração para M-C para as propriedades do cimento aos 28 dias para os ensaios de compressão confinados

Figura 3.10 - Meridiano de Compressão, Cortante e Tração para MC para as propriedades medidas aos 28 dias para os ensaios não confinados

Figura 4.1 - Esquematização dos parâmetros necessários para definir a malha através do inp 
Figura 4.2 - Esquema para a geração de gráficos desde o arquivo de entrada até ao de saída

Figura 4.3 - Esquematização do modelo de elementos finitos utilizado para a análise para o estudo de caso 1

Figura 4.4 - Dimensões dos anulares A e B para o caso de Duplo Mecanismo

Figura 4.5 - Coordenadas dos pontos $A_{1}, A_{2}, B_{1}$ e $B_{2}$ para o para 0 caso de Duplo Mecanismo

Figura 4.6 - Dimensões dos anulares A1 e A2 e B1 e B2 para o caso da Lei Híbrida

Figura 4.7 - Coordenadas dos pontos $A_{1}, A_{2}, B_{1}$ e $B_{2}$ para o para 0 caso da Lei Híbrida

Figura 4.8 - Avaliação a longo prazo do fechamento do ponto A ao longo do tempo

Figura 4.9 - Avaliação a curto prazo do fechamento do ponto $\mathrm{A}$ ao longo do tempo

Figura 4.10 - Esquematização do modelo de elementos finitos utilizado para a análise para o estudo de caso 2

Figura 4.11 - Fechamento do anular depois da perfuração

Figura 4.12 - Análise das tensões de von Mises na direção radial no sal após a perfuração do poço

Figura 4.13 - Espaço anular no processo de reconstrução do aço e bombeamento do cimento com esquematização das pressões no interior do revestimento $(\mathrm{Pi})$ e exterior $(\mathrm{Pe})$

Figura 4.14 - Reativação dos elementos de cimento a) recorrendo à metodologia cement decoy b) sem recurso à metodologia cement decoy c) sem recurso à metodologia cement decoy com aumento do estado de tensão inicial da rocha salina

Figura 4.15 - a) Dimensão do anular para o cimento com a evolução das propriedades mecânicas e módulo de elasticidade mínimo e máximo b) zoom in 
Figura 4.16 - a) Tensão tangencial no revestimento, pasta de cimento e sal b) tensão radial no revestimento, cimento e sal para $E$ constante de $13,5 \mathrm{GPa}$

Figura 4.17 - Comparativo do deslocamento do anular para a análise que considera a temperatura de $60^{\circ} \mathrm{C}$ durante as reações de hidratação

Figura 4.18 - a) Estado de tensão e envoltória de ruptura para a pasta de cimento em diferentes idades b) zoom in 


\section{Lista de tabelas}

Tabela 2.1 - Principais constituintes do pó de cimento (clínquer)

Tabela 2.2 - Propriedades mecânicas do cimento em função do tempo

Tabela 2.3 - Valores médios de resistência à tração obtida por compressão diametral (ft) e relação entre ft e fc para pastas curadas em diferentes idades à $60{ }^{\circ} \mathrm{C}$ com respectivos coeficientes de variação (CV)

Tabela 3.1 - Parâmetros elastoplásticos para o aço

Tabela 3.2 - Parâmetros da Lei de Potência adotados para a halita brasileira

Tabela 3.3 - Parâmetros da lei de Duplo Mecanismo adotados para a halita brasileira

Tabela 3.4 - Parâmetros elásticos adotados para a halita brasileira

Tabela 3.5 - Parâmetros que relacionam os critérios D-P com M-C

Tabela 3.6 - Aumento do declive e ordenada na origem para modelo D-P1 ao longo do tempo para ensaios à compressão

Tabela 4.1 - Caracterização das camadas acima da profundidade de controle 


\section{Introdução}

É unânime entre a comunidade científica, que propriedades físicas conferidas pela bainha cimentícia são cruciais à integridade e ao bom funcionamento do poço de petróleo. Embora dê suporte mecânico ao revestimento, a principal função da bainha é assegurar a estanqueidade a qualquer líquido ou gás, tanto na fase de construção como na fase de produção. A integridade do poço é perdida caso essa estanqueidade seja comprometida.

A perda de integridade pode se dar em condições de curto ou longo prazo. Entende-se como causas de curto prazo aquelas que ocorrem antes da fase da produção, como por exemplo a perda da pressão hidrostática da matriz cimentícia ou a não remoção completa das lamas de perfuração que dá lugar a brechas na matriz. Já as causas para a perda de integridade de longo prazo ocorrem durante a produção. As altas pressões e temperaturas, o ataque químico e as propriedades físicas intrínsecas à rocha perfurada e à pasta de cimento são causas assinaláveis para este problema. Martins et al. (1997), Bourgoyne et al. (2000) e Heathman \& Beck (2006) enunciam exemplos de poços que perderam a integridade a curto ou a longo prazo. Os autores alertam para as consequências irreparáveis naturais e financeira das catástrofes e o papel fundamental que a pasta de cimento deve desempenhar para que acidentes sejam evitados.

Neste assunto, o desenvolvimento de novas formulações de pastas de cimento, estudos experimentais e de campo, formulações analíticas e modelos numéricos têm sido levados a cabo para que os engenheiros entendam, simulem e prevejam o desempenho do poço na sua vida útil com o intuito de reduzir o risco de imprevistos.

Este trabalho utiliza uma abordagem numérica para estudar os fenômenos físicos que se desenvolvem no poço. A literatura mostra que recentes modelos numéricos não lineares têm procurado simular integralmente os processos reais pelo qual o poço passa como a perfuração, reconstrução e produção do poço. Nestas modelagens, o estado de tensão de cada processo é transmitido à subsequente etapa 
para que na fase de produção o estado de tensão seja fielmente reproduzido no poço e seus constituintes. Bosma et al. (1999) é o trabalho percursor desta tendência. Desde então, outros autores têm seguido essa corrente e utilizado esta metodologia. Entre vários autores, pode-se enunciar o trabalho de Ravi et al. (2002), Ravi \& Bosma (2005), Heathman \& Beck (2006), Gray et al. (2007) e Schreppers (2015). Todos estes autores analisaram poços atravessando formações porosas de fluência desprezível.

Gray et al. (2007) concentram-se nas várias fases da modelagem, desde a construção até a produção do poço e todas as considerações que devem ser feitas em cada fase. Contudo, na fase da construção, os autores admitem que a reconstrução do revestimento e da pasta de cimento é feito num único passo. Essa suposição infere que a pasta de cimento aumenta de rigidez nula para a sua rigidez de referência aos 28 dias instantaneamente. Nenhum dos autores enunciados anteriormente trata deste assunto nos seus trabalhos, pelo que se assume que todos seguiram esta suposição.

No contexto de poços perfurados no sal, a fluência passa a ser a ação proeminente da formação e esta deve ser contabilizada nas modelagens. Vários autores procuram simular e contabilizar o histórico do poço. Trabalhos como Poiate et al. (2006) e Costa et al. (2010) analisam a integridade do poço tendo em conta as fases de perfuração, reconstrução do revestimento, do cimento e a fase de produção. Empregando essa mesma metodologia, Macay (2011) e Macay \& Fontoura (2014) apresentam uma modelagem no mesmo contexto, adicionam a evolução das propriedades mecânicas no tempo da pasta de cimento e explicam a modelagem do processo de bombeamento da pasta de cimento e reconstrução do revestimento em diferentes etapas, conforme já tinha sido anteriormente referenciado por Ravi \& Bosma (2005).

Macay (2011) e Macay \& Fontoura (2014) mostram que no intervalo de tempo de 11 dias, período em que se dá a evolução das propriedades mecânicas, existe um aumento assinalável das tensões tangenciais e radiais na pasta de cimento. Perante este cenário, infere-se que a implementação deste passo é fulcral na modelagem do histórico de tensões do poço. Este novo estado de tensão, resultante do período de cura, seria passado para os consequentes passos e a condição inicial de tensão do cimento no início da produção seria superior ao estado de tensão hidrostático da pasta de cimento. 
Trabalhos experimentais e estudos de campo como os de Martins et al. (1997) e Cooke et al. $(1983,1984)$ apresentam resultados contraditórios aos resultados numéricos de Macay (2011) e Macay \& Fontoura (2014). Os autores dão enfoque à evolução da pressão hidrostática no cimento hidratado no anular e concluem que existe uma perda de pressão hidrostática durante as reações de hidratação da pasta ao invés de um aumento.

Assim, pode-se concluir que existe uma desconformidade entre as observações experimentais e de campo com os modelos simulados numericamente. Essa constatação reforça a necessidade de mais pesquisas sobre a modelagem da construção de poços.

\section{1.}

\section{Objetivos da pesquisa}

O principal objetivo desta pesquisa é avaliar o processo de solidificação da pasta de cimento e entender se esses efeitos são proeminentes para a avaliação da integridade do poço e chegar a uma metodologia que modele o fenômeno.

Outro objetivo deste trabalho é melhorar as técnicas de geração de modelos de elementos finitos para a simulação da construção de poços de petróleo automatizada - rápida geração de modelos e rápida extração de resultados.

Em conformidade com as recentes publicações, este presente trabalho tem o objetivo de implementar um modelo numérico que tome em conta o histórico das tensões desde a perfuração até a solidificação da pasta de cimento aos 28 dias. A avaliação dos efeitos da produção no estado de tensão foi descartada do estudo.

Uma vez que o trabalho foca nas condições anteriores à produção, procurouse definir um modelo constitutivo que simule a fluência primária e secundária da rocha salina com base nas formulações já presentes na literatura - Lei de Duplo Mecanismo e Lei de Potência.

\section{2.}

\section{Estrutura da dissertação}

A dissertação é dividida em 5 capítulos que abordam cronologicamente as etapas para a elaboração deste trabalho.

O capítulo 1 tem como objetivo introduzir o problema e os objetivos do trabalho. 
O capítulo 2 visa fazer um levantamento bibliográfico e um enquadramento geral do tema proposto. Procura também dar o conhecimento suficiente da matéria ao leitor para que consiga entender os capítulos subsequentes.

O capítulo 3 apresenta os modelos constitutivos e metodologias de modelagem utilizadas para simular os materiais halita, pasta de cimento e aço. Neste capítulo são apresentadas comparações entre os modelos constitutivos empregues e outros presentes na literatura.

O capítulo 4 apresenta dois estudos de caso. No primeiro caso, a pasta de cimento é negligenciada e estuda-se o fechamento do poço a partir de três teorias de fluência. No segundo caso, a pasta de cimento é considerada e apresentam-se os resultados que tomam em conta a evolução das propriedades mecânicas da pasta de cimento ao longo do período da cura. Além disso, é apresentada a metodologia utilizada para simular as diferentes fases de construção do poço.

O capítulo 5 apresenta as conclusões e sugestões futuras. 


\section{2 \\ Revisão da literatura}

Toda a literatura é consensual. A pasta de cimento é o elemento que confere a integridade ao poço de petróleo. Gray et al. (2007) afirmam que a bainha cimentícia é o coração de qualquer poço. É esperado que o constituinte confira suporte mecânico ao revestimento, mas principalmente assegure o suporte de todo o poço e a estanqueidade a qualquer líquido ou gás, tanto na fase de construção como na fase de produção. A bainha de cimento interage mecanicamente tanto com a formação rochosa como com o revestimento, suportando tensões originadas pela produção e tensões geradas pelos processos geológicos. Bosma et al. (1999) corrobora e confirma que as propriedades mecânicas da pasta de cimento nos poços têm-se mostrado cruciais na integridade do poço. A pasta de cimento deve atender ainda às exigências estruturais e de estanqueidade tanto a curto como a longo prazo. Alertam que no projeto, muitas vezes, os requisitos a longo prazo não são tomados em conta e que essa omissão pode ser arriscada. Na fase de produção, o poço está sujeito a variações de pressões e temperaturas. Também atestam que a bainha tem um papel crucial no poço garantindo o suporte do revestimento e preenchendo o espaço anular entre o revestimento e a rocha. Segundo Willson et al. (2002), outra vantagem do cimento em poços perfurados no sal é a uniformização de tensões no revestimento metálico pela fluência do sal. Caso este não seja empregue, o revestimento pode sofrer cargas não uniformes.

A pasta de cimento, no contexto petrolífero, deve atender as seguintes demandas tanto a curto como a longo prazo:

- Ligar a formação rochosa ao revestimento e dar suporte ao revestimento.

- Proteger a zona de produção de petróleo e o revestimento metálico de problemas de corrosão.

- Atuar como um selante contra contaminação de reservas de água que podem ser usadas para uso doméstico.

- Ajudar a prevenir blowout devido a altas pressões de gás na zona adjacente ao revestimento $(\mathrm{SCP})$. 
- Evitar perdas de circulação.

O Capítulo vigente dá uma ampla visão dos constituintes do cimento, do processo de construção e efeitos a curto e longo prazo que culminem na perda de integridade do poço.

\section{1.}

\section{Composição química do cimento}

De acordo com NBR 5732:1991, o cimento Portland é um “Aglomerante hidráulico obtido pela moagem de clínquer Portland ao qual se adiciona, durante a operação, a quantidade necessária de uma ou mais formas de sulfato de cálcio. " De acordo com a NP EN 197-1:2001 “o cimento é um ligante hidráulico, isto é, um material inorgânico finamente moído que, quando misturado com água, forma uma pasta que faz presa e solidifica devido a reações e processos de hidratação e que, depois da solidificação completa, conserva a sua resistência mecânica e estabilidade debaixo de água ".

O ligante cimento Portland é amplamente utilizado em várias áreas. Quimicamente, é formado por quatro principais constituintes $-\mathrm{C}_{3} \mathrm{~S}, \mathrm{C}_{2} \mathrm{~S}, \mathrm{C}_{3} \mathrm{~A}$ e $\mathrm{C}_{4} \mathrm{AF}$. As quantidades de cada constituinte estão expressas na Tabela 2.1.

Tabela 2.1 - Principais constituintes do pó de cimento (clínquer)

\begin{tabular}{cccc}
\hline Designação & Constituição Química & Abreviatura & Quantidade (\%) \\
Silicato tricálcico & $3 \mathrm{CaO} \cdot \mathrm{SiO}_{2}$ & $\mathrm{C}_{3} \mathrm{~S}$ & 20 a 65 \\
Silicato bicálcico & $2 \mathrm{CaO} . \mathrm{SiO}_{2}$ & $\mathrm{C}_{2} \mathrm{~S}$ & 10 a 55 \\
Aluminato tricálcico & $3 \mathrm{CaO} \cdot \mathrm{Al}_{2} \mathrm{O}_{3}$ & $\mathrm{C}_{3} \mathrm{~A}$ & 0 a 15 \\
Ferro aluminato tetracálcico & $4 \mathrm{CaO} . \mathrm{Al}_{2} \mathrm{O}_{3} \cdot \mathrm{Fe}_{2} \mathrm{O}_{3}$ & $\mathrm{C}_{4} \mathrm{AF}$ & 5 a 15
\end{tabular}

Descrevendo cronologicamente as reações na presença de água para cada constituinte, chega-se à conclusão através da Figura 2.1 que o primeiro constituinte a reagir é o $\mathrm{C}_{3} \mathrm{~A}$. A reação dos aluminatos é rápida e exotérmica e confere uma rigidez quase instantânea à pasta. Neste momento é imprescindível a inclusão do gesso entra na composição do cimento. Este combina-se rapidamente com os aluminatos e cria dificuldades à sua hidratação. Apesar do $\mathrm{C}_{3} \mathrm{~A}$ ser o agente responsável pela vulnerabilidade da pasta de cimento a ataques de sulfatos, este é indispensável ao cimento pois tanto o $\mathrm{C}_{3} \mathrm{~A}$ como o $\mathrm{C}_{4} \mathrm{AF}$ funcionam como fundentes (qualquer substância química que baixa o ponto de fusão) na produção 
de cimento. Em seguida, o $\mathrm{C}_{3} \mathrm{~S}$ é o constituinte que reage, e por último o $\mathrm{C}_{2} \mathrm{~S}$. O $\mathrm{C}_{4} \mathrm{AF}$ é quimicamente estável.

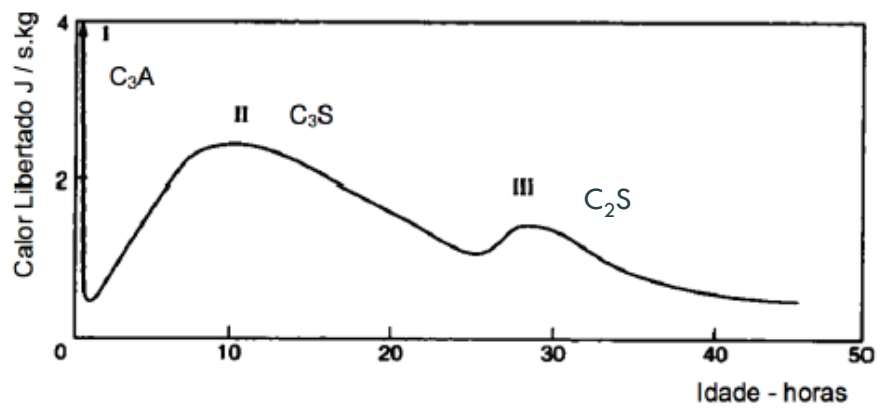

Figura 2.1 - Períodos para os quais os constituintes do clínquer reagem.

A Figura 2.2 mostra que, embora o $\mathrm{C}_{3} \mathrm{~A}$ reaja prontamente, a resistência mecânica do cimento hidratado é dada pelos constituintes $\mathrm{C}_{3} \mathrm{~S}$ e $\mathrm{C}_{2} \mathrm{~S}$ com velocidades de reação diferentes. Embora o $\mathrm{C}_{2} \mathrm{~S}$ demore mais a reagir, este é tão responsável pela resistência da pasta de cimento a longo prazo.

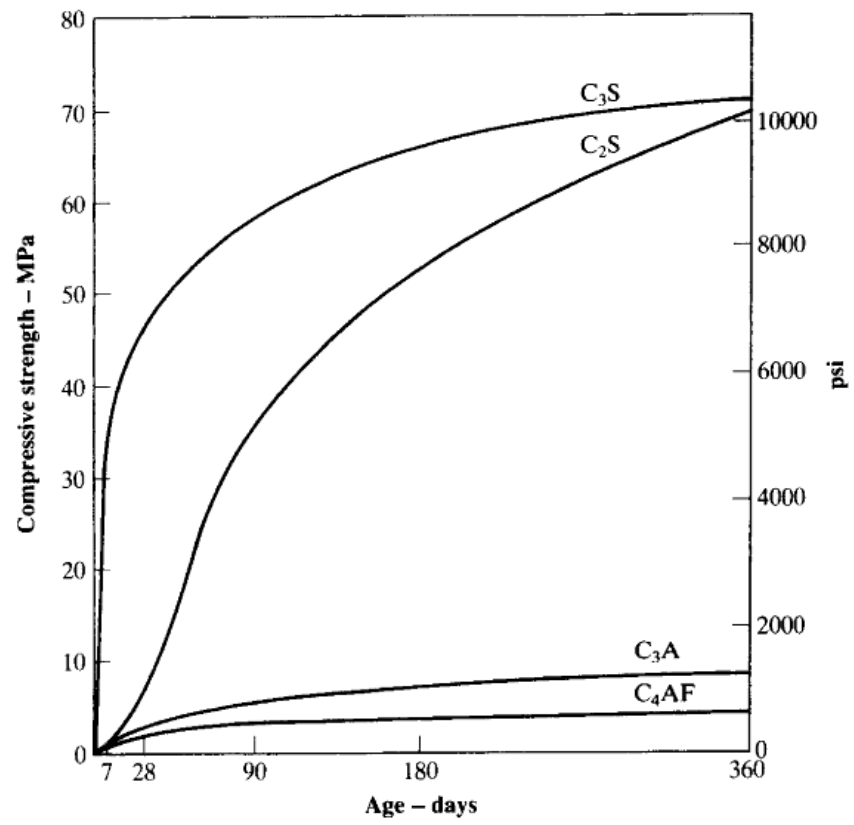

Figura 2.2 - Resistência de cada constituinte do cimento e velocidade de reação

No final, os constituintes do clinquer hidratados dão origem à pasta de C-S$\mathrm{H}$ e ao hidróxido de Cálcio $\left(\mathrm{Ca}(\mathrm{OH})_{2}\right)$. O C-S-H, também designado de gel C-S-H, representa 50 a $60 \%$ da matriz cimentícia hidratada e é determinante para as propriedades do cimento hidratado. Crê-se que este gel forme uma camada à volta dos grãos de cimento que adia a sua hidratação. Este intervalo de tempo é chamado de período de indução ou período dormente. Este período dormente é alterado consoante a finura do grão (reação de hidratação mais rápida porque a superfície de contato do cimento com a água torna-se maior) e com a quantidade dos 
constituintes. Por exemplo, cimentos com maior quantidade de $\mathrm{C}_{3} \mathrm{~S}$ do que $\mathrm{C}_{2} \mathrm{~S}$ ganham pega mais rápido $\left(\mathrm{C}_{3} \mathrm{~S}\right.$ reage mais prontamente), como mostrado na Figura 2.1. O produto da reação $\mathrm{Ca}(\mathrm{OH})_{2}$ representa 20 a $25 \%$ da matriz e, reagindo com a água, faz com que o $\mathrm{pH}$ da pasta suba para valores superiores a 12,5. Este também colabora mecanicamente, contudo a sua contribuição é inferior ao do gel C-S-H. Embora em menores quantidades, o sulfatoaluminato de cálcio hidratado também ocupa 15 a $20 \%$ do volume de sólidos dos reagentes hidratados. Este constituinte não é determinante na resistência da pasta de cimento e acaba por ser o constituinte responsável pela vulnerabilidade dos materiais cimentícios ao ataque de sulfatos (produto da combinação de gesso com o $\mathrm{C}_{3} \mathrm{~A}$ ). $\mathrm{O}$ restante do volume da pasta de cimento é ocupado por partículas de cimento não hidratadas.

Metha \& Monteiro (2006, p. 241) referem que os cimentos são produzidos e classificados dependendo das quantidades e do tipo de matérias primas utilizadas na mistura. Os dois órgãos mais conhecidos para a categorização de cimentos são a ASTM (American Society for Testing and Materials), que classifica cimentos para construções civis, e a API (American Petroleum Institute), que classifica cimentos para serem utilizados em poços de A a J. As classes variam de acordo com a quantidade de constituintes do cimento

Michaux et al. (1989) apresentam um estudo de arte com o desenvolvimento cronológico das diferentes pastas de cimento utilizadas em poços de petróleo. Os cimentos A, B e C foram desenvolvidos na década de 50 com a capacidade de serem utilizados em poços com até $1.800 \mathrm{~m}$. Quimicamente, os cimentos de classe B têm menos $\mathrm{C}_{3} \mathrm{~A}$ que os de classe $\mathrm{A}$ e foram elaborados para resistir ao ataque de sulfatos. Os da classe $\mathrm{C}$, com o objetivo de formarem pega mais rapidamente, têm mais $\mathrm{C}_{3} \mathrm{~A}$ e $\mathrm{C}_{3} \mathrm{~S}$ e os grãos finos. Os das classes $\mathrm{D}$ e $\mathrm{E}$ foram cimentos desenvolvidos para poços até 4.250 metros de profundidade. Estes têm uma menor concentração de $\mathrm{C}_{3} \mathrm{~A}$ e $\mathrm{C}_{3} \mathrm{~S}$ e os inertes não tão finos, com o propósito de ter um efeito retardador.

Metha \& Monteiro (2006, p. 241) dão a indicação de que a indústria petroleira atualmente utiliza os cimentos de classe $\mathrm{H}$ e $\mathrm{G}$ com recurso a aditivos como retardadores e aceleradores de pega. Na década de 60 os aditivos começaram a ter um papel mais proeminente na indústria. Foram inventados os Cimentos $\mathrm{H}$ e G. Estes são semelhantes ao tipo B, tendo o cimento $\mathrm{H}$ partículas mais grosseiras que o G. 
Contudo, os retardadores se revelam instáveis a altas temperaturas pelo que a indústria formulou um novo cimento (classe J) que suporta temperaturas superiores a $120^{\circ} \mathrm{C}$ sem a necessidade da adição de retardadores de pega. Nestas condições, as reações de hidratação são mais rápidas e verifica-se uma diminuição da capacidade resistente à compressão a longo prazo e de trabalhabilidade. Este comportamento está relacionado com o menor índice de porosidade no gel C-S-H constatado nestas condições, o que leva a um menor período de indução. Além da pasta de cimento perder a sua impermeabilidade, o seu comportamento mecânico muda durante a hidratação e depois da pega. Nestas situações o uso de retardastes e outros aditivos se torna imprescindível para a cimentação do poço. A literatura chama a este fenômeno de strength retrogression. Para evitar o fenômeno descrito, é adicionado ao cimento areia ou pó de sílica. Independentemente dos avanços conquistados pela ciência na formulação de novas pastas, estas ainda não são suficientes para fazer face a certos desafios. Michaux et al. (1989) atestam no seu estado de arte que aos $400^{\circ} \mathrm{C}\left(\sim 750^{\circ} \mathrm{F}\right)$ o cimento Portland torna-se instável e, nestes casos, têm de ser empregados outros tipos de selantes.

\section{2.}

\section{Aplicação da pasta cimentícia}

A aplicação da pasta de cimento é feita como exemplificado na Figura 2.3. No processo de perfuração do poço, a lama de perfuração é bombeada. Depois, o revestimento metálico é colocado. Através do interior do revestimento metálico, a pasta é bombeada entre os dois plugs. Depois de deslocar o volume de cimento até à cota pretendida, o Bottom plug é rompido e deixa o cimento sair enquanto que Top plug continua a pressionar a pasta de cimento. Uma vez que a pasta de cimento é um fluido mais pesado e imexível com o fluido de perfuração, esta empurra-o através do anular. No final do processo, um displacement fluid (que pode ser o líquido de perfuração) encontra-se dentro do revestimento e no anular a pasta de cimento. 


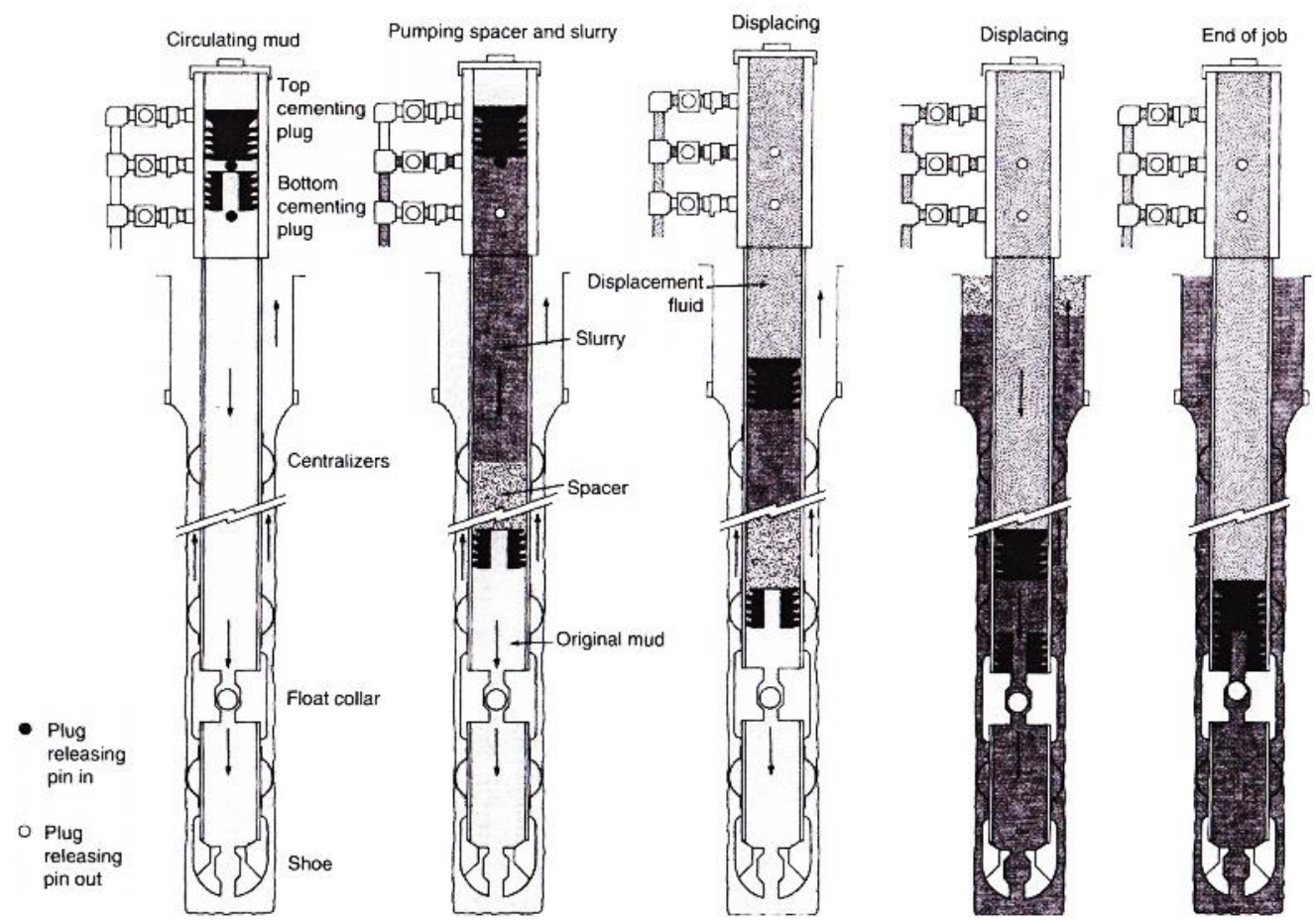

Figura 2.3 - Fases de reconstrução do poço desde a reconstrução do revestimento até ao cimento no anular

Os tempos com que estas atividades se desenrolam são apresentados na Figura 2.4, por Cooke et al. $(1983,1984)$. Os autores colocaram 6 dispositivos que medem pressão e temperatura no anular. Na mesma figura, são apresentadas as pressões hidrostáticas no anular para o dispositivo 1 e 2. Apesar de Cooke et al. (1983) atestem que o primeiro sensor regista incrementos de pressão passados 11 minutos após o bombeamento do cimento, Cooke et al. (1984) apresenta a Figura 2.4 que parece contradizer o trabalho precedente. $\mathrm{O}$ autor desta dissertação de mestrado estimou um tempo de cerca de 40 minutos através da figura, admitindo que o início do bombeamento foi aos 740 e o registo do incremento aos 780 minutos. Admite-se que o segundo dispositivo registou o incremento de tensão aos 800 minutos. Então, o movimento da pasta tem uma velocidade de $0,46 \mathrm{~m} / \mathrm{s}$ no anular enquanto que no interior do revestimento tem $1,11 \mathrm{~m} / \mathrm{s}$. O bombeamento é interrompido aos 840 minutos. Aos 870 minutos a pressão hidrostática atinge o valor máximo. 

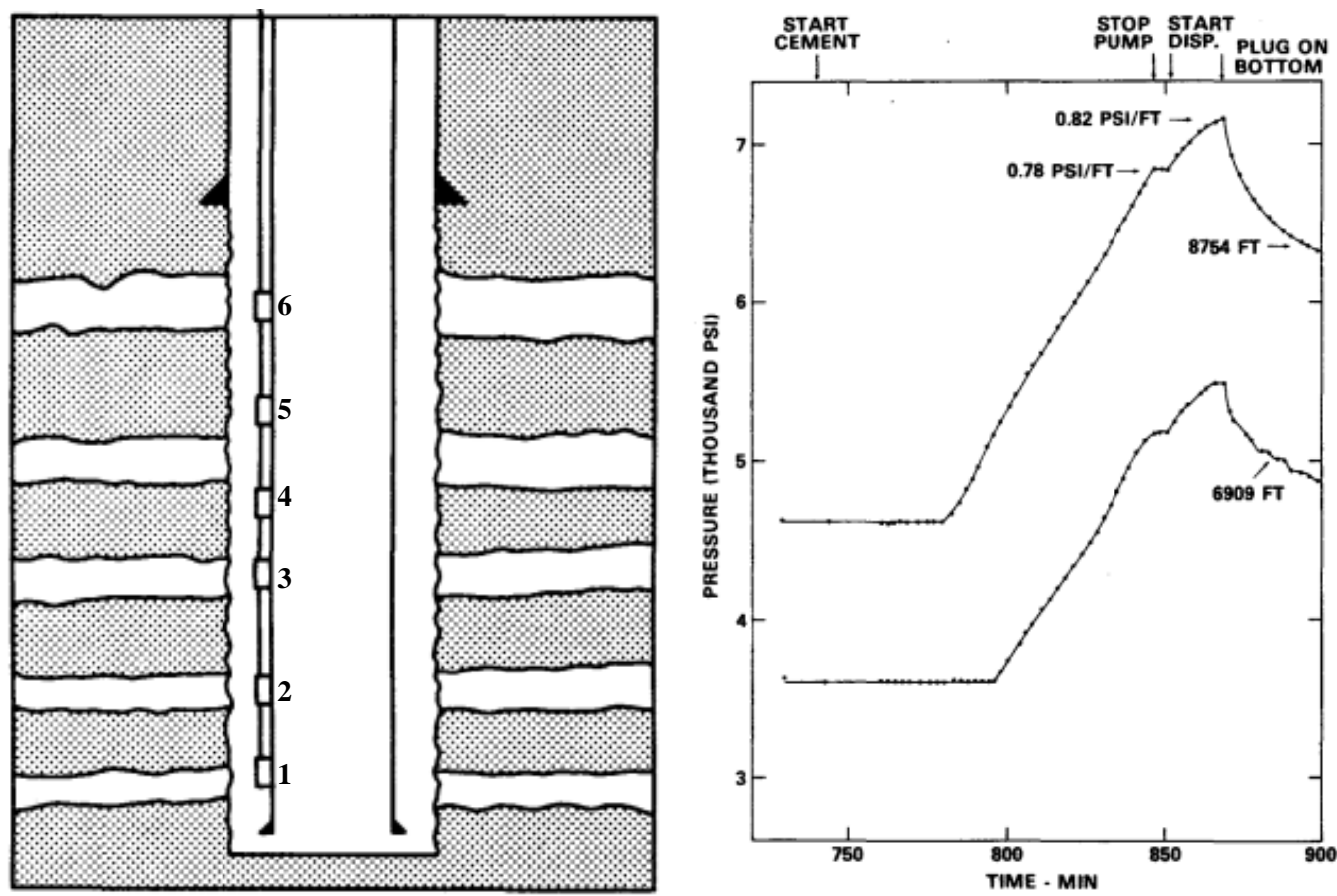

Figura 2.4 - Posição dos dispositivos que medem temperatura e pressão no interior do anular e evolução da pressão hidrostática no anular para o dispositivo 1 e 2 na cimentação do poço Fonte: Cooke et al. (1984)

\section{3. \\ Causas de fissuração/perda de ligação e consequências}

Vários autores alertam que o cimento deve ser escolhido para atender as solicitações de curto e longo prazo de forma a que probabilidade de perda de integridade poço seja diminuta. Entenda-se que o termo curto prazo se refere a acontecimentos que têm lugar antes da fase de produção e longo prazo têm lugar no desenrolar da produção.

Entre as várias causas para a perda de integridade a curto prazo, destacamse neste capítulo a perda de pressão hidrostática no anular, que está diretamente ligado à perda de volume da pasta de cimento por retração por secagem e autógena. Outras causas possíveis para a perda de integridade a curto prazo são a baixa densidade da pasta de cimento em relação ao gás alojado na formação (apenas aplicável a rochas porosas) ou a ineficiente remoção das lamas de perfuração. Neste capítulo também será apresentada a evolução das propriedades mecânicas do cimento para diferentes pressões e temperaturas durante hidratação.

Embora as causas a longo prazo fujam do escopo do presente estudo, um levantamento do estado-da-arte foi elaborado. A longo prazo, o poço pode perder a sua integridade caso o poço apresente condições extremas de temperatura e pressões 
ou ataque químico do sal. As propriedades mecânicas da pasta de cimento e rocha salina perfurada também podem afetar a integridade do poço.

\subsection{1.}

\section{Curto prazo}

Martins et al. (1997) atestam que a perda de integridade a curto prazo pode ser originada por gases que migrem através da matriz cimentícia no processo de construção (Figura 2.5). Estes efeitos prejudiciais da migração de gases podem se revelar bastante onerosos.

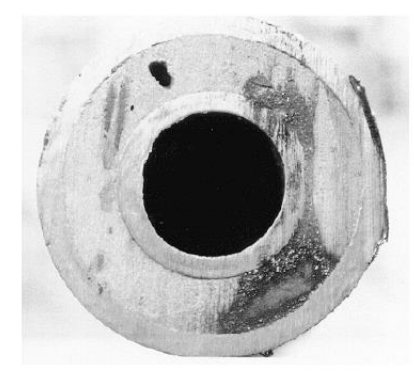

a)

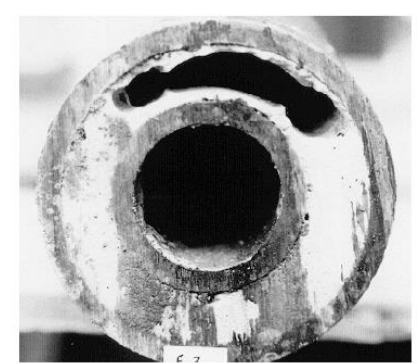

b)

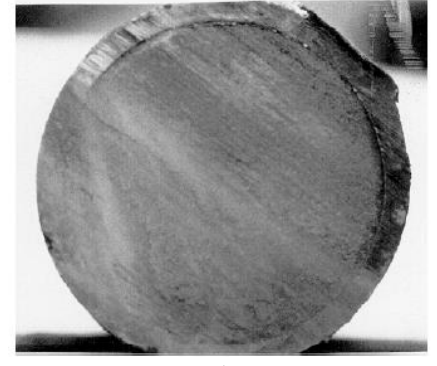

c)

Figura 2.5 - a) canal de gás b) severo canal de gás c) Microannulus migração de gás Fonte: Martins et al. (1997)

A indústria tem buscado soluções para contornar os problemas a curto prazo. A título de exemplo, adições como impermeabilizantes ou expansores de volume, têm ajudado a melhorar a resposta da pasta a estes problemas de migração de gases. Podem ser enunciados trabalhos como os de Abbas et al. (2014) que apresentam por exemplo adições de polímeros para diminuir a perda de fluidos e a quantidade de água livre.

Mesmo existindo soluções para o problema, Martins et al. (1997) atestam que mais de 3.000 poços nos Estados Unidos da América foram abandonados devido a problemas de migração de gás. No contexto brasileiro, a Petrobras gastou num só poço 600 mil dólares em trabalhos de reparação relacionados com a migração de gás a curto prazo.

Três aspectos importantes relacionados à migração de gases através da pasta de cimento são abordados: Pressão Hidrostática, Retração e Propriedades no tempo da pasta címentícia. 


\subsubsection{1. Pressão hidrostática}

Shadravan \& Amani (2012) afirmam que a pressão hidrostática do cimento é fulcral para que não se registe migração de gases na fase de cimentação. A pressão no anular deve ser suficiente para impedir a invasão de líquidos e gases. Por outro lado, essa pressão tem que ser controlada para não fraturar a rocha envolvente. Para que a se gere um micro anular entre o cimento e o sal, a poropressão do cimento deve ser inferior à poropressão da rocha. Uma vez que a rocha salina foge a essa caracterização, o efeito passa a ser insignificante no contexto.

Cooke et al. (1983) acreditam que esta redução de pressão se deve à diminuição de volume da pasta de cimento quando este ganha pega (retração autógena e perda de água) e às tensões cisalhantes geradas entre a bainha de cimento, a rocha salina e revestimento metálico. O mecanismo para perda de água livre é explicado por Dusseault et al. (2000). Quando a cimentação é feita frente a uma rocha porosa com cimento de relação a/c elevado, existe uma percolação de água livre através dos poros de rocha uma vez que a pressão hidrostática da pasta é superior à da água. Este mecanismo é explicado com mais detalhe na seção 2.3.1.2 abaixo - Retração da pasta de cimento.

Li et al. (2016) descortinam com rigor o mecanismo responsável pelo decaimento da pressão hidrostático no anular ao longo do tempo no período de gelation do cimento. Os autores atestam que, de todas as teorias apresentadas, a mais aceite e consensual na literatura é a teoria clássica da migração de gás desenvolvida e proposta por Sutton et al. (1984) apud Li et al. (2016). Esta teoria clássica pondera uma redução de pressão no anular devido às tensões tangenciais geradas entre o cimento, formação e revestimento.

Em comparação com dados experimentais, Li et al. (2016) concluem que a teria clássica sobrestima o decaimento da pressão hidrostática no anular visto que é uma teoria simplificada. Esta teoria contabiliza apenas as forças tangenciais pelo equilíbrio entre a pressão no topo e na base da baínha do cimento. Chenevert \& Jin (1989) adicionam à teoria clássica as variáveis tempo, mudanças de volume e propriedades reológicas da pasta. Autores admitem que a evolução das propriedades adesivas varia com o tempo e com as propriedades reológicas. O peso específico da 
mesma não é única e exclusivamente função da cota analisada, mas também da variação de volume da pasta - perda de água e retração.

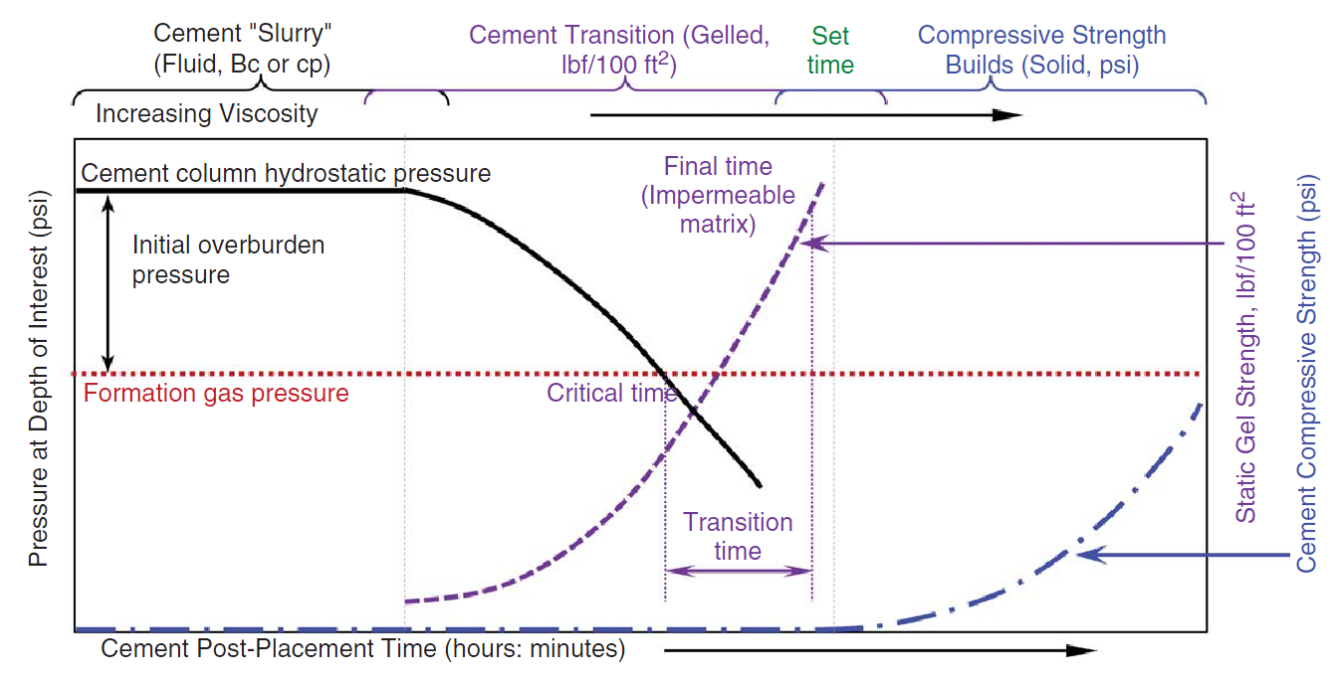

Figura 2.6 - Evolução da pressão e resistência do cimento na cura Fonte: Li et al. (2016)

Contudo, Li et al. (2016) adverte que estas teorias clássicas são limitadas. Na microscopia do material, existem fenômenos que são desprezados e o contato entre cimento, a formação e o revestimento não é puramente cisalhante como adoptado pela teoria clássica. Não contabilizando estes fatores, a formulação clássica prevê diminuições de pressões hidrostáticas no anular superiores às habitualmente medidas em laboratório.

Ensaios experimentais e de campo têm corroborado a de que existe uma diminuição da pressão hidrostática ao longo do tempo. Martins et al. (1997) ensaiaram 16 pastas de cimento produzidas com diferentes formulações e chegaram à conclusão que a maior redução da pressão hidrostática verificada foi de $30 \%$. Os autores verificam que os resultados são consensuais com os de Cooke et al. (1983, 1984) que monitoraram a pressão da pasta de cimento em 7 poços diferentes. A Figura 2.7 exibe a pressão hidrostática da pasta de cimento e a temperatura a que este se encontra em várias cotas (em que a cota 1 é a mais profunda e a cota 6 a menos profunda). Verifica-se um aumento brusco de temperatura no anular por conta das reações de hidratação. Portanto, a pasta de cimento ganha pega para um estado de tensão hidrostático próximo ao da pressão hidrostática do fluido de perfuração. 

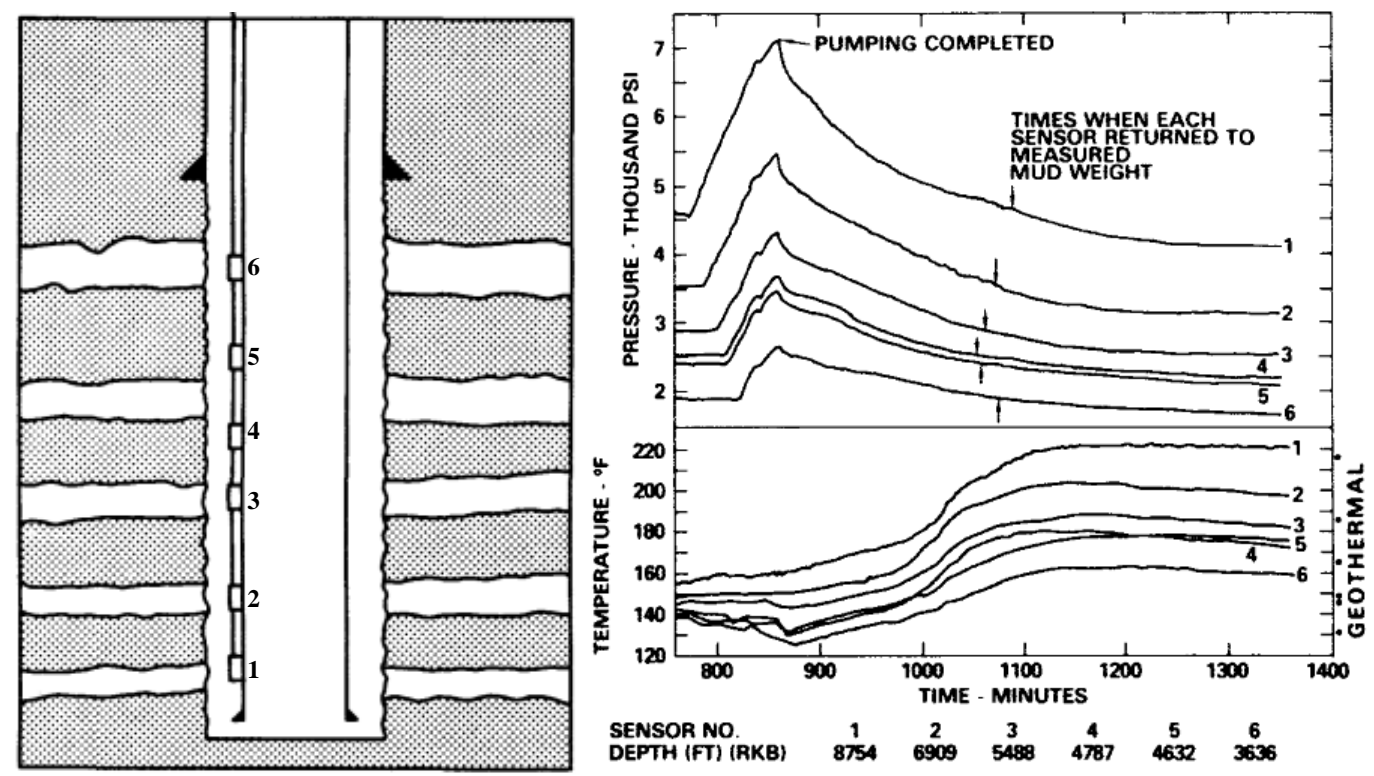

Figura 2.7 - Pressão hidrostática e temperatura em diferentes cotas Fonte: Cooke et al. (1983)

Quando os poços perfurados em rochas salina, Hunter et al. (2009) advertem que a perda de pressão hidrostática no período de solidificação da pasta de cimento pode resultar numa diminuição do anular devido à ação da fluência de sal. Este efeito é contabilizado na modelagem levada a cabo neste trabalho. Advertem ainda que o sal pode chegar a tocar no revestimento ainda antes do cimento ter desenvolvido propriedades físicas que restrinjam essa deformação.

\subsubsection{2. \\ Retração da pasta de cimento}

O efeito da retração é uma das causas para a perda de pressão hidrostática. Neville \& Brooks (2010) classificam a retração como um acontecimento independente do nível de tensão à qual o corpo está sujeito. Porém, este efeito pode introduzir tensões adicionais caso a estrutura cimentícia esteja restringida ao movimento. Ao querer retrair, aumento de tensões podem provocar a ruptura da pasta. Gray et al. (2007) reforçam dizendo que, enquanto a ligação entre o cimento/revestimento e cimento/formação continuar intacta, a retração do cimento leva à deformação do revestimeno e da formação, que pode culminar na plastificação dos mesmos ou do próprio cimento com consequente fissuração/ruptura. Caso essa ligação seja perdida, a pasta de cimento irá retrair livremente, perdendo a ligação entre a formação geológica e o revestimento formando-se os micro anulis. 
Num contexto geral, a retração pode ser subdividida em três tipos, secagem, carbonatação e química. A retração por secagem acontece devido à retirada da água que não foi utilizada na hidratação. A retração por carbonatação acontece devido à interação das moléculas de $\mathrm{CO}_{2}$ com as de $\mathrm{Ca}(\mathrm{OH})_{2}$ que forma $\mathrm{CaCO}_{3}$. A contaminação do cimento por carbonatação resulta numa contração do cimento conhecida por retração de carbonatação. A retração química acontece devido às reações de hidratação durante a cura da pasta de cimento.

No contexto de poços, Ravi et al. (2006) afirmam que a retração mais relevante é a retração química. Uma parcela desta retração é apelidada de retração autógena. Esta retração é contabilizada através da diferença macroscópica do volume do corpo cimentício devido às reações de hidratação. A Figura 2.8 mostra esquematicamente a retração química e autógena no processo de hidratação da pasta cimentícia.

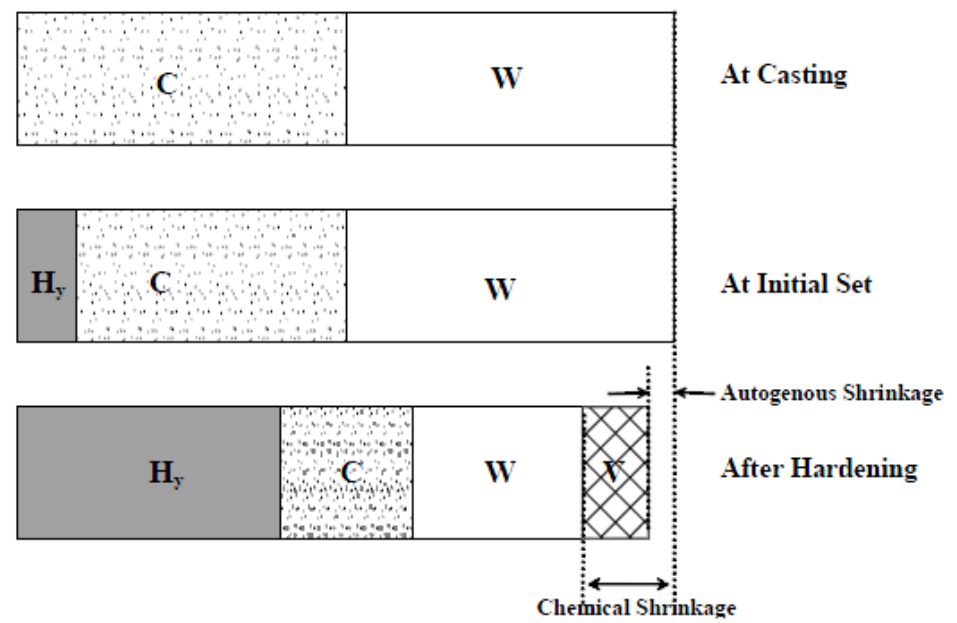

Figura 2.8 - Esquema da retração externa (ou autógena), interna e química. $\mathrm{C}=$ Cimento desidratado, $\mathrm{W}=$ Água, $\mathrm{H}_{\mathrm{y}}=$ Produto hidratado e $\mathrm{V}$ = vazios gerados pela hidratação Fonte: Japan (1999) apud Holt (2001)

Segundo Holt $(2001,35)$ a retração química passa por 3 fases, a fase líquida, a fase de formação do esqueleto sólido e a fase de solidificação. Na primeira fase, representada pelo trecho $\mathrm{AB}$ na Figura 2.9 a), a retração autógena é igual à retração química, isto é, o esqueleto da pasta de cimento não tem rigidez suficiente para restringir as deformações autógenas. Ravi et al. (2006) chama este tipo de retração autógena de externa. Na formação do esqueleto sólido, representada pelo trecho BC na Figura 2.9 a), existe um fenômeno de auto-dessecação que consiste numa secagem dos poros internos da pasta e contração dos mesmos por fluência. Nesta fase, a matriz de cimento já tem rigidez para resistir a contração do volume do corpo. A poropressão cai devido à formação de meniscos o que induz tensões 
internas no material que o contrai. Na fase de solidificação, representada pelo trecho CD na Figura 2.9 a), a retração possível será resultado da auto-dessecação uma vez que a estrutura címenticia já apresenta um esqueleto completo formado com uma rigidez associada. Ravi et al. (2006) chama a este tipo de retração autógena que se dá pelo colapso de poros de retração de interna. Assim, a retração autógena tende a estabilizar. Caso a cura aconteça num meio provido de água ou impermeável, a auto-dessecação e a consequente contração dos poros é impossibilitada.

As conclusões descritas anteriormente são corroboradas pela Figura 2.9b) que apresenta a retração autógena e a retração química em função do tempo. Concluise então que sensivelmente até às 5 horas, o cimento exibe um comportamento líquido pois a retração química é igual à retração autógena. Das 5 horas em diante, a retração autógena tende a estabilizar devido à formação do esqueleto sólido.

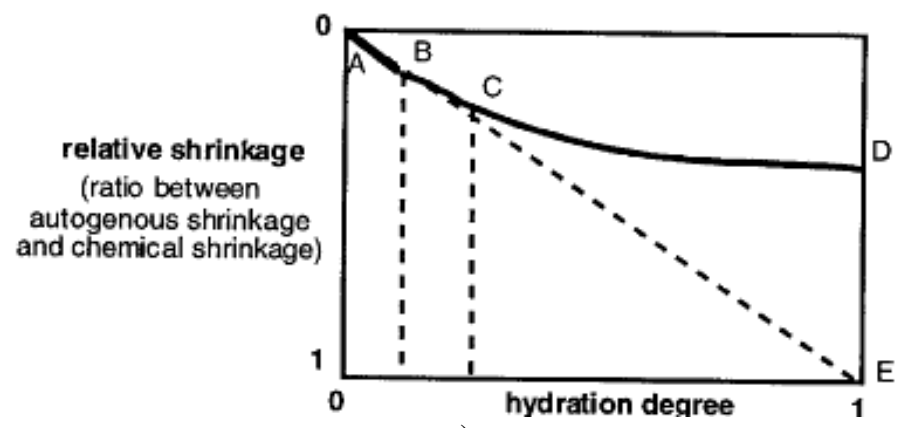

a)

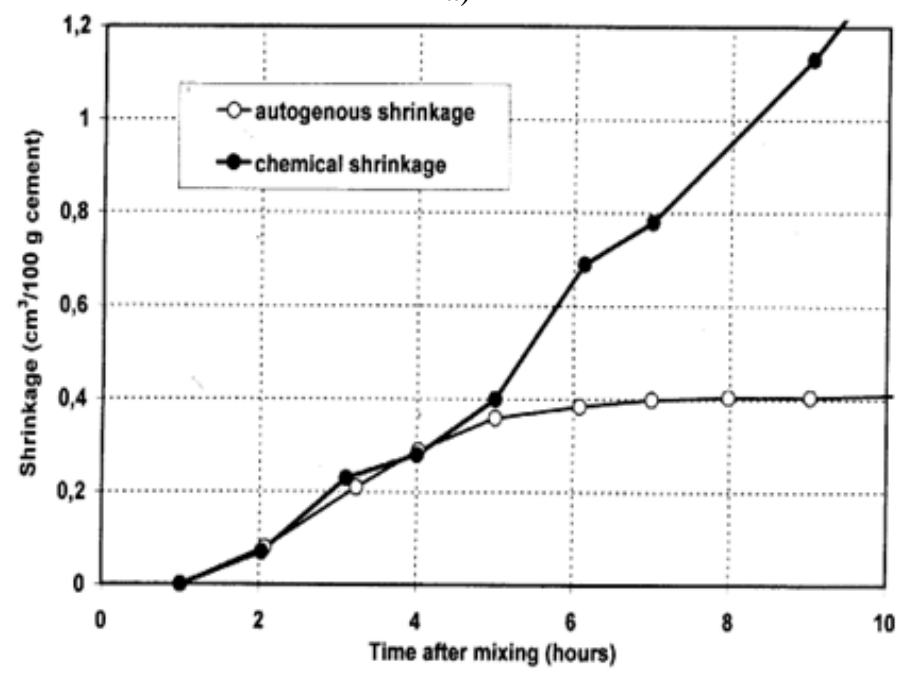

b)

Figura 2.9 - a) Evolução da retração externa em função do grau de hidratação Fonte: Acker (1988) apud Holt (2001)

b) Evolução da retração externa e retração química em função do tempo Fonte: Hammer (1999)

O fenômeno de formação de meniscos é detalhadamente descortinado por Metha \& Monteiro (2006, p. 469). Quando na superfície de qualquer corpo deixa de haver simetria molecular, a energia das moléculas de uma superfície será 
diferente da energia das moléculas no interior do volume. A natureza tenta trazer o corpo em análise para a sua mínima energia. Neste processo, a redução da energia das moléculas superficiais implica em contração do volume resultando numa pressão interna superior à pressão externa. A diferença destas pressões é apelidada de pressão de superfície. Tubos capilares e bolhas de ar em líquidos apresentam curvaturas côncavas (meniscos) pelo que a diferença de pressões ou "pressão de superfície" será negativa, isto é, a pressão exterior será superior à pressão do líquido. Na pasta de cimento, este fenômeno é verificado em capilares e bolhas de ar alojadas dentro da pasta cimentícia. Este processo provoca a contração e consequente aumento de tensões internas que vão aumentado até ao final do tempo de cura onde estabiliza o estado de tensão. Aí, por fluência, o material sofrerá uma deformação viscoelástica no tempo.

Modelagens, como as de Gray et al. (2007), consideram um valor de deformação com taxa constante no tempo de 5\%. Embora a retração seja uma variável dependente da temperatura e da composição química do cimento, os autores simplificam e consideram-na com uma taxa constante no tempo. Já Ravi \& Bosma (2005) consideram que as reações de hidratação provocam uma diferença de volume média de $4 \%$. Os autores também concordam que este valor de retração pode estar sujeito a variáveis não contabilizadas pelo modelo como por exemplo a expansibilidade da pasta de cimento por conta de fluido proveniente da formação rochosa ou por bolhas de gás dentro da matriz cimentícia.

\subsubsection{3. Propriedades da pasta em função do tempo - efeito da temperatura e pressão na cura}

Pfeifle et al. (2001) realizaram um estudo experimental e numérico do cimento classe G, com relação água/cimento de 4,3 e 5,2 galões/saco, e concluem que o módulo de elasticidade e a resistência à compressão aumentam no tempo devido às reações de hidratação. Concluem também que a resistência à compressão da pasta de cimento é dependente do tempo e do confinamento a que este está sujeito e o módulo de elasticidade depende exclusivamente do tempo. Para o aferimento das propriedades elásticas, módulo de elasticidade e coeficiente de Poisson, os autores realizaram 22 ensaios de compressão não confinados aos 1, 3, 7, 14 e 28 dias. Os corpos de prova do experimento foram curados a $20^{\circ} \mathrm{C}$, com 
pressão atmosférica e dimensões de 4 polegadas de diâmetro por 8 polegadas de altura. Pfeifle et al. (2001) Mackay (2011) e Mackay \& Fontoura (2014) utilizam as propriedades mecânicas no cimento da Tabela 2.2 nos seus modelos numéricos.

\begin{tabular}{ccc}
$\begin{array}{c}\text { Tabela 2.2 - Propriedades mecânicas do cimento em função do tempo } \\
\text { Intervalo de Tempo } \\
\text { [dias] }\end{array}$ & $\begin{array}{c}\text { Módulo de } \\
\text { Elasticidade [MPa] }\end{array}$ & $\begin{array}{c}\text { Coeficiente de } \\
\text { Poisson }\end{array}$ \\
\hline $0,0-0,6$ & 1504,98 & 0,286 \\
$0,6-1,0$ & 2850,62 & 0,286 \\
$1,0-2,0$ & 4514,96 & 0,286 \\
$2,0-3,0$ & 5957,98 & 0,286 \\
$3,0-4,0$ & 7179,67 & 0,286 \\
$4,0-5,0$ & 8197,76 & 0,286 \\
$5,0-6,0$ & 9029,92 & 0,286 \\
$6,0-7,0$ & 9693,89 & 0,286 \\
$7,0-9,0$ & 10818,2 & 0,286 \\
$9,0-11,0$ & 11030,67 & 0,286 \\
$>11,0$ & 13500,00 & 0,286 \\
\hline
\end{tabular}

Fonte: Pfeifle et al. (2001)

Rocha (2015) faz também um estudo experimental às pastas de cimento classe $\mathrm{G}$, com relação água/cimento de 0,44 e $0,25 \%$ de adição de antiespumante em relação à massa de cimento. A autora mostra que, com o aumento da temperatura na cura, a velocidade das reações de hidratação da pasta aumenta e consequentemente os valores das propriedades mecânicas também. Na Tabela 2.3 são apresentadas as propriedades mecânicas, ao longo do tempo de cura, retiradas do ensaio à tração e compressão uniaxial a $60^{\circ} \mathrm{C}$.

Tabela 2.3 - Valores médios de resistência à tração obtida por compressão diametral (ft) e relação entre ft e fc para pastas curadas em diferentes idades à $60^{\circ} \mathrm{C}$ com respectivos coeficientes de

\begin{tabular}{cccccc}
\hline $\begin{array}{c}\text { Idade } \\
{[\text { dias] }}\end{array}$ & $\begin{array}{c}\mathbf{f c} \\
{[\mathbf{M P a}]}\end{array}$ & $\begin{array}{c}\mathbf{\varepsilon c} \\
{[\boldsymbol{\mu \varepsilon}]}\end{array}$ & $\begin{array}{c}\mathbf{E} \\
{[\mathbf{G p a}]}\end{array}$ & $\begin{array}{c}\mathbf{f t} \\
{[\mathbf{M P a}]}\end{array}$ & $\begin{array}{c}\mathbf{f t} / \mathbf{f c} \\
{[\mathbf{a d i m} .]}\end{array}$ \\
\hline 0,25 & 15,09 & 3302,85 & 7,17 & 1,66 & 0,11 \\
0,58 & 29,16 & 4039,18 & 10,69 & 3,04 & 0,10 \\
1 & 35,19 & 3999,88 & 11,56 & 3,40 & 0,10 \\
3 & 41,89 & 3630,88 & 14,42 & 4,02 & 0,10 \\
7 & 49,96 & 5049,13 & 14,37 & 4,92 & 0,10 \\
14 & 52,73 & 6674,19 & 13,82 & 5,70 & 0,11 \\
28 & 52,36 & 4881,75 & 14,53 & 5,90 & 0,11 \\
\hline
\end{tabular}

Fonte: Rocha (2015) 
Rocha (2015) também estudou o impacto da pressão nas propriedades mecânicas da pasta na cura da mesma. Conclui que os corpos curados sob uma pressão não registaram aumentos significativos no valor de resistência à compressão quando comparado com a pasta curada à pressão atmosférica. Justificase este aumento com compactação e o adensamento do volume dos corpos de prova. Como já anteriormente apresentado por Pfeifle et al. (2001), Rocha (2015) chega também à conclusão que o módulo de elasticidade depende unicamente do tempo e da temperatura, e independe do tipo de carregamento. Então a pressão também não tem influência neste parâmetro.

A evolução da tensão resistente à tração em corpos de prova curados sob pressão foi estudada. Os resultados mostraram uma diminuição de resistência quando comparados com corpos curados sob pressão atmosférica. A autora justifica que a inesperada diminuição se deve à rápida descompressão do corpo de prova que provocou microfissuras. Portanto, esse resultado deixa de ser validado.

Além do comportamento uniaxial, Rocha (2015) estuda o comportamento triaxial da pasta de cimento com 7 dias e curada a uma temperatura de $60^{\circ}$. Os ensaios foi realizado a pressões confinantes de 6,9 e 13,8 MPa. A Figura 2.10 apresenta a envoltória de ruptura no plano $\sigma_{\mathrm{n}}-\tau$.

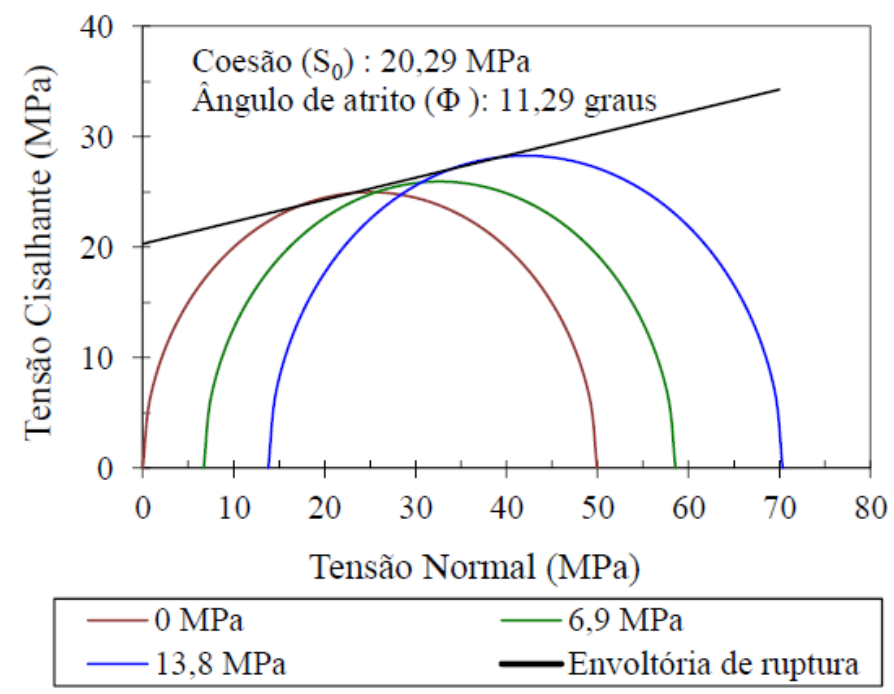

Figura 2.10 - Círculos de Mohr e envoltória de ruptura da pasta com 7 dias de cura a $60^{\circ} \mathrm{C}$ Fonte: Ramos (2015)

Não encontrando referência na literatura sobre as propriedades evolutivas do cimento para poços de petróleo, utilizou-se a formulação apresentada por Sims et al. (1966) que relaciona a resistência uniaxial (presente em Rocha (2015)) com a resistência triaxial para tensões confinantes iguais nas duas direções. Os autores 
pesquisaram a relação entre a resistência à compressão confinada e não confinada para pastas de cimento com relação água/cimento de 0,40. O teste envolveu 110 ensaios com pressão confinante de 0,5000, 10000, 15000 e 20000 psi para vários graus de saturação dos interstícios da pasta cimentícia. Os autores propõem uma fórmula empírica que, com base na resistência à compressão do ensaio desconfiando $\left(\sigma_{u}\right)$ e na pressão confinante $\left(\sigma_{2}\right)$, prevê a resistência à compressão confinada $\left(\sigma_{1}\right)$ através da seguinte expressão:

$$
\left(\frac{\sigma_{1}}{\sigma_{u}}\right)=1+a\left(\frac{\sigma_{2}}{\sigma_{u}}\right)^{b}
$$

Não havendo referência em Rocha (2015) sobre o processo de secagem, admitiu-se a pasta de cimento saturada. Nestas condições, Sims et al. (1966) aconselham valores de $\mathrm{a}=1,249$ e $\mathrm{b}=0,865$.

Estabelecendo-se pressões confinantes de 0, 6,9 e 13,8 $\mathrm{MPa}$, as tensões uniaxiais de compressão apresentadas na Tabela 2.3 e a equação (2.1), conseguiuse estimar o ângulo de atrito e coesão para cada idade de cura do cimento. Os resultados apresentados na Figura 2.11 são o produto dessa análise.

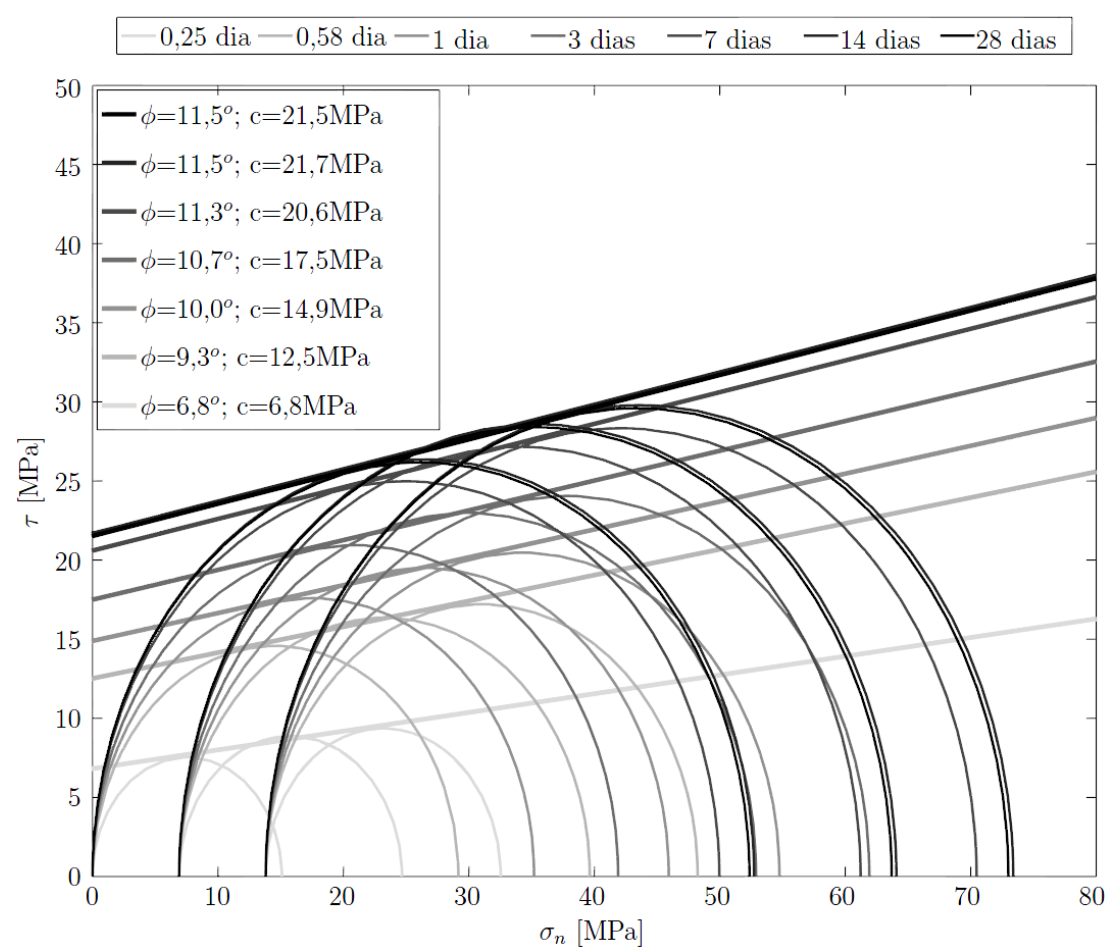

Figura 2.11 - Círculos de Mohr e envoltória de ruptura da pasta com 0,25, 0,58, 1, 3, 7, 14 e 28 dias para ensaios à compressão com corpos de prova curados a $60^{\circ} \mathrm{C}$

Os resultados experimentais da Figura 2.10 (obtidos de Rocha (2015)) para o $7^{\circ}$ dia de cura apresentam valores de coesão de 20,29 MPa e de ângulo de atrito de $11,29^{\circ}$. Os resultados calibrados através da equação (2.1), apresentados na Figura 
2.11, são próximos dos experimentais para o $7^{\circ}$ dia de cura, com coesão de 20,60 MPa e ângulo de atrito de $11,33^{\circ}$. Os ensaios à tração não confinada não foram contemplados para a obtenção das propriedades.

A Figura 2.12 mostra os valores de ângulo de atrito tendo apenas em conta os ensaios não confinados da pasta de cimento, tanto à tração como à compressão. Os valores de resistência não confinada são os apresentados na Tabela 2.3.

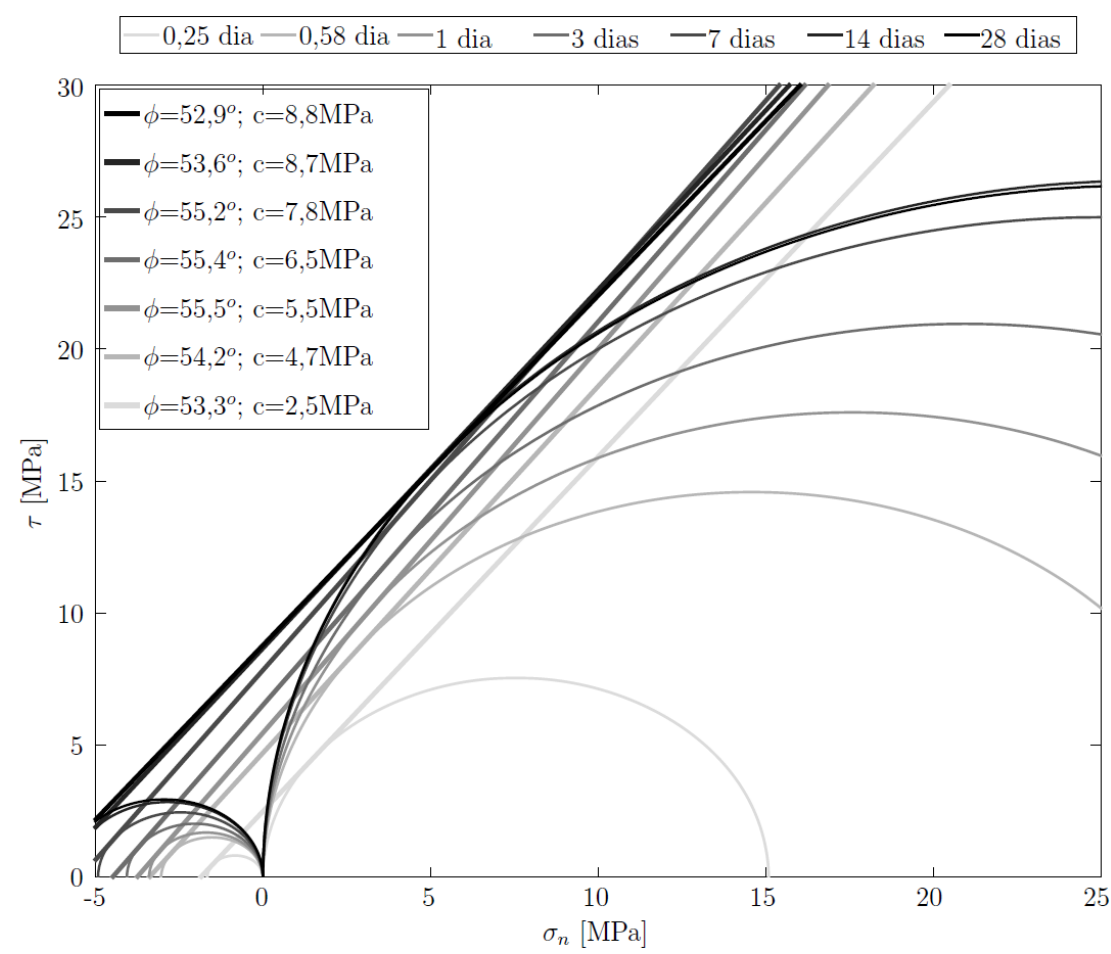

Figura 2.12 - Círculos de Mohr e envoltória de ruptura da pasta com 0,25, 0,58, 1, 3, 7, 14 e 28 dias para ensaios não confinados com corpos de prova curados a $60^{\circ} \mathrm{C}$

Verifica-se então que o ângulo de atrito e a coesão do material variam bastante dependendo do confinamento do material.

\subsection{2.}

\section{Longo prazo}

Embora não seja objeto de estudo do presente trabalho, definiram-se como acontecimentos de longo prazo aqueles que causam a perda de integridade durante a produção. Altas pressões e temperaturas, ataque químico e propriedades intrínsecas à pasta de cimento podem ser enunciadas como as causas para esse fim. Como já mencionado, o anel cimentício deve manter a sua integridade e garantir a ligação à rocha e ao revestimento metálico. A integridade do poço é perdida caso exista fissuração da pasta de cimento ou deformações plásticas que culminem em migração de fluidos. Neste caso, também devem ser analisadas as tensões principais 
entre os materiais, pois a perda de ligação da pasta de cimento com os outros constituintes acontece por grandes diferenças entre as mesmas.

A Figura 2.13 mostra os vários modos de perda de integridade aos quais o poço está sujeito. Além destes padrões apresentados pela Figura 2.13, Shadravan et al. (2014) mostra que a pasta de cimento que fissura por cortante, no plano 2D, exibe um padrão de fissura do gênero semeado sem direção específica.

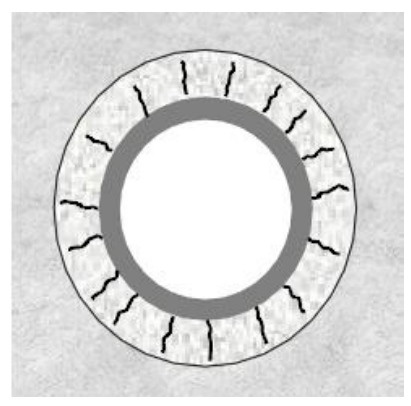

a)

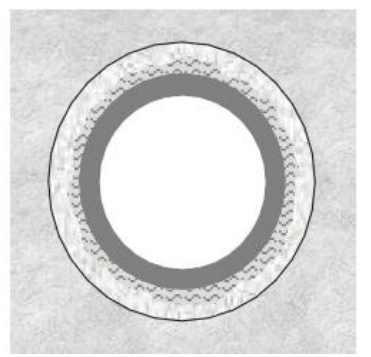

d)

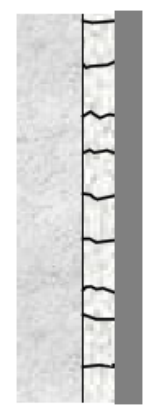

b)

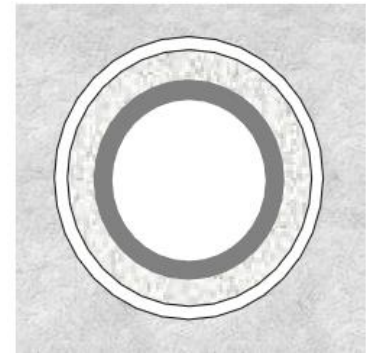

e)
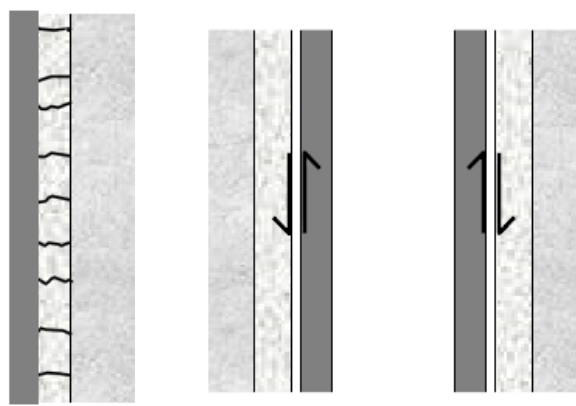

c)

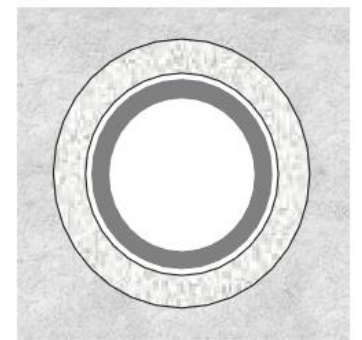

f)

Figura 2.13 - a) fissuração circunferencial b) fissuração axial c) ruptura por cisalhamento d) esmagamento do cimento e) descolamento do sal-cimento f) descolamento do cimento-aço Fonte: Schreppers (2015)

Em poços, a perda de integridade dá origem a acidentes. Heathman \& Beck (2006) apresentam vários exemplos onde poços no Golfo do México falharam desastrosamente nas primeiras semanas de produção por conta de um subdimensionamento do revestimento e da bainha da pasta cimentícia. Existem enormes mudanças de temperatura e pressão na fase de produção e estas não foram contabilizadas na fase de projeto. Assim se conclui que nesta fase é necessário entrar com efeitos de longo prazo. Os autores também advertem que se deve evitar a todo o custo o desmoronamento de poços dado que, além dos onerosos trabalhos de reconstrução, este pode condenar por completo as reservas de gás/petróleo existentes.

No decorrer da produção, pode existir um incremento de pressão no anular devido à passagem de gases pelo cimento. A indústria chama a estas variações de pressão no anular do cimento de Sustained casing pressure (SCP). OLF 117 apud 
Eikas (2012) define SCP como "pressure in any well annulus that is measurable at the wellhead and rebuilds when bled down, not caused solely by temperature fluctuations or imposed by the operator". Existindo brechas na matriz cimentícia, pode ocorrer uma migração de fluidos proveniente da formação rochosa e/ou do interior do revestimento resultando num aumento de pressões medidas no topo do poço na fase de produção. Esse aumento de pressão pode colocar em causa a integridade de todo o poço. Xu \& Wojtanowicz (2001) reforçam que a maior causa de SCP é originada devido a uma pobre cimentação. Acrescentam ainda que pastas de cimento com alto teor de água/cimento têm alta permeabilidade e que os gases podem conseguir atravessar esta matriz cimentícia, chegando ao topo, resultando em SCP. Bourgoyne et al. (2000) enunciam vários exemplos de ruína de poços devido a fenômenos de SCP, com consequências ambientais e financeiras catastróficas. Eikas (2012) adverte ainda que quando o anel cimentício perde a ligação com o revestimento, é praticamente impossível a sua reparação, reforçando a premissa de que é imperativo escolher com precaução a pasta cimentícia a utilizar e modelá-la corretamente na fase de projeto. Este tem sido um problema recorrente na indústria. Vignes et al. (2006) apud Eikas (2012) reportam que de 406 poços analisados, 75 apresentaram problemas de integridade num período de 30 anos.

Ravi \& Bosma (2005) e Ravi (2006) acrescentam ainda que, normalmente, a indústria tem tido como único critério de dimensionamento as ações a curto prazo. Assim, problemas como a estabilidade térmica e química em condições de altas temperaturas e pressões, resistência à retração interna e reposta mecânica às ações na fase de produção, são usualmente negligenciadas.

\subsubsection{1.}

\section{Altas pressões e altas temperaturas (HTHP)}

Shadravan \& Amani (2012) definem um poço em condições HTHP (high temperature/ high pressure) quando a pressão deste é superior a 10.000 psi e a temperatura é superior a $149^{\circ} \mathrm{C}$. Embora estes valores de definição de HPHT possam mudar de acordo com o país, região ou companhia, estes são cada vez mais comuns pois relatam que a indústria já encontrou e explorou os poços de fácil extração de hidrocarbonetos. Restam agora explorar os de difícil exploração.

Ao longo da vida útil do poço, a degradação da bainha cimentícia é, na maior parte das vezes, causada por tensões induzidas devido a variações de pressão e 
temperatura na fase de operação. Estas variações de pressão/temperatura, segundo Shadravan et al. (2014), dão lugar a tensões cíclicas, que levam à fadiga dos materiais. Estas diferenças de temperatura/pressões são originadas sobretudo devido a operações de EOR (enhanced oil recovery), que são técnicas de indução de calor ou pressão nos reservatórios com o intuito de melhorar a rentabilidade do poço produtor. Como referido anteriormente, uma possível causa das variações de pressão/temperatura é o SCP. Além do mais, o revestimento metálico e a pasta de cimento reagem de forma diferente ao aumento de pressões e temperaturas. Os padrões de fissuração observados neste contexto são o esmagamento da pasta de cimento por um aumento de tensão radial, a fissuração radial por tração tangencial e surgimento de microannuls interior ou exterior.

Shadravan et al. (2014) fazem um estudo laboratorial às bainhas cimentícia com condições de altas temperaturas $\left(330^{\circ} \mathrm{F}\right)$ e com pressão inicial de $15000 \mathrm{psi}$ com alternâncias de 1000, 2000 e 5000psi. Chega-se à conclusão que, independentemente do tipo de pasta de cimento ou da diferença de pressão exercida, as primeiras fraturas observadas foram na direção radial em todos os casos.

A modelagem tem vindo a auxiliar a indústria na previsão destes fenômenos. Shahri et al. (2005) afirmam que a variação de temperatura e pressão são variáveis que devem ser tomadas em conta quando se executa a modelagem numérica e se escolhe o selante. Os autores estudaram dois casos. No primeiro, a pressão dentro do poço é superior à da formação e no segundo a pressão da formação é superior à do poço. No primeiro caso observou-se que entre os materiais as tensões são de grande magnitude e existiam deformações o que levou a concluir que estas pressões podem levar a uma perda de ligação parcial. No segundo caso, o modelo portou-se da mesma forma até que foi aumentada a temperatura em 200\%. Dessa forma o poço tornou-se instável e a ligação entre a pasta de cimento e o revestimento deixou de depender das propriedades do cimento o que levou a uma perda de ligação dos mesmos levando o poço ao colapso. Com os dois exemplos conclui-se que estas duas ações devem ser consideradas.

\subsubsection{2.}

\section{Ataque químico do sal}

Neville \& Brooks (2010) definem a permeabilidade como a facilidade com que líquidos ou gases conseguem atravessar a pasta de cimento e que esta 
propriedade deve ser de interesse para estruturas estanques e resistentes ao ataque químico.

O trabalho de Hunter et al. (2009) dá indicações dos problemas ao cimentar poços frente ao sal devido à interação química entre a formação salina e a pasta cimentícia. O sal é uma rocha solúvel e a pasta de cimento tem água na sua gênese.

Poiate Jr. (2012) alerta que se devem ter cuidados redobrados quando a frente de cimentação é uma rocha salina e utilizar processos químicos que evitem a dissolução da rocha salina. No processo de dissolução, o sal interfere com a matriz cimentícia, enfraquecendo-a e alterando o tempo de pega. Estes efeitos devem ser contabilizados na modelagem.

\subsubsection{3.}

\section{Propriedades intrínsecas ao cimento}

Vários autores referem que a probabilidade de encontrar fissuras na pasta de cimento também se relaciona com os materiais utilizados na construção do poço.

Ravi et al. (2006) afirmam que a indústria tem utilizado unicamente a resistência à compressão da pasta de cimento para definir se este se classifica como próprio ou impróprio ao poço em análise, deixando esquecidas outras propriedades como módulo de elasticidade, coeficiente de Poisson e parâmetros plásticos. A Figura 2.14 apresenta a curva carga-deslocamento para o cimento 1 e a Figura 2.15 para o cimento 3 . O cimento 1 é um cimento classe $\mathrm{G}$ e o cimento 3 é um cimento classe $\mathrm{G}$ com adição de polímeros.

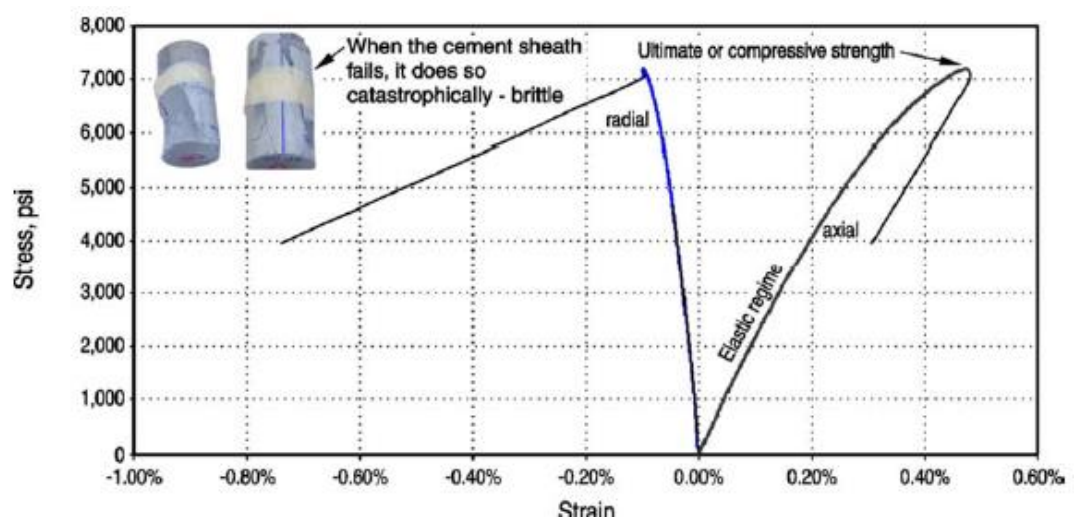

Figura 2.14 - Gráfico carga-deslocamento para o cimento1 Fonte: Ravi et al. (2006) 


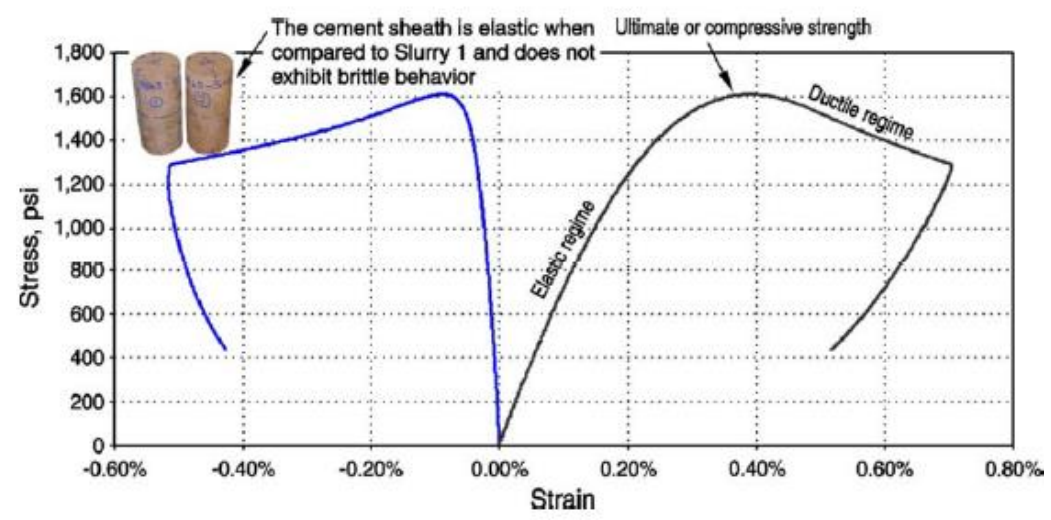

Figura 2.15 - Gráfico carga-deslocamento para o cimento3 Fonte: Ravi et al. (2006)

O estudo destes autores mostra que a pasta de cimento que apresentou menor dano, e consequentemente uma melhor resposta, foi aquele que evidenciava um maior módulo de tenacidade, uma vez que pode absorver maior energia antes de quebrar (cimento3). A pasta de cimento em questão era também o que apresentava o mais baixo módulo de elasticidade. Assim, mostram que a resistência à compressão não é um parâmetro confiável e decisivo na escolha do selante e devese dar importância à tenacidade do material.

Heathman \& Beck (2006) fizeram o seu estudo nas propriedades mecânicas da pasta e chegaram à conclusão que as pastas de cimento empregadas nos poços deveriam apresentar módulos de elasticidade e ângulos de atrito muito mais baixos do que apresentam. Valores de coesão, tensão de tração e coeficiente de Poisson deveriam ser maiores. Também concluíram que a retração autógena deve ser diminuida.

Bosma et al. (1999) estuda várias formulações de cimentos e várias propriedades mecânicas das rochas. Eles concluem que as diferenças entre o módulo de elasticidade da rocha e o da pasta cimentícia têm um papel preponderante no mecanismo de ruptura que a pasta apresenta. Também concluíram que as fissuras da pasta cimentícia dependem da tensão inicial e das caraterísticas da ligação entre a bainha de cimentícia e a formação rochosa. Quatro diferentes condições de tensão inicial no selante foram simuladas. No primeiro caso, simularam a retração depois da cura do selante. Para isso consideraram o estado de tensão inicial do selante nulo no anular. No segundo caso, os autores idealizaram o selante como sem retração. Não existindo retração, a tensão inicial será a tensão hidrostática. No terceiro caso, simularam o cimento como um material expansível, 
com uma tensão hidrostática mais a tensão devido à restrição dessa mesma expansão. A instabilidade do poço foi o último cenário analisado. Neste caso, o fechamento do mesmo nunca é equilibrado pelas forças no interior do poço.

\section{4.}

Considerações finais

A definição da pasta de cimento ideal pode ser resumida, conforme transcrito a seguir de (POIATE JR., 2012, p. 100).

“Como recomendação final, a pasta otimizada deve apresentar um rápido desenvolvimento e altos valores finais da resistência à compressão; uma maior resistência ao ataque químico; água livre zero; bom controle de filtrado e a menor porosidade possível." 


\section{3 Modelos constitutivos e validação}

O capítulo vigente tem como objetivo enumerar e validar os modelos constitutivos utilizados na presente dissertação para representar nas simulações numéricas o comportamento dos materiais envolvidos: o aço, a pasta de cimento e o sal.

\section{1.}

Aço

Para o aço adotou-se comportamento elastoplástico segundo o critério de von Mises com os parâmetros apresentados no trabalho de Fossum \& Fredrich (2007). O autor simula o material como elástico perfeitamente plástico com uma lei de fluxo associado à lei de escoamento. Este critério contempla a plastificação apenas por aumento da tensão desviadora. Os parâmetros elastoplásticos para a definição do material são apresentados na Tabela 3.1.

Tabela 3.1 - Parâmetros elastoplásticos para o aço

\begin{tabular}{ccc}
\hline Caractere/unidade & Descrição & Valor \\
\hline $\mathrm{E}(\mathrm{GPa})$ & Módulo de elasticidade (ou Young) & 210 \\
$v($ adim. $)$ & Coeficiente de Poisson & 0,30 \\
$\sigma_{\mathrm{y}}(\mathrm{MPa})$ & Tensão uniaxial de escoamento & 438
\end{tabular}

Fonte: Fossum \& Fredrich (2007)

\section{2.}

Sal

A rocha salina é uma rocha sedimentar de alta solubilidade, ativação geoquímica com um comportamento continuo de fluência. Esta fluência é caracterizada pelo incremento de deformações para tensão constante por conta do efeito viscoso e pode ser dividida em três estágios. A Figura 3.1 mostra esses diferentes estágios. O primeiro estágio (fluência primária ou transiente) é caracterizado pela desaceleração da deformação até atingir uma taxa de deformação constante. A fase em que a taxa de deformação é constante, chamada de fluência 
secundária ou estacionária, é a fase dominante. Por fim, a fluência terciária, é caracterizada por um amento de taxa de deformação e consequente ruptura.

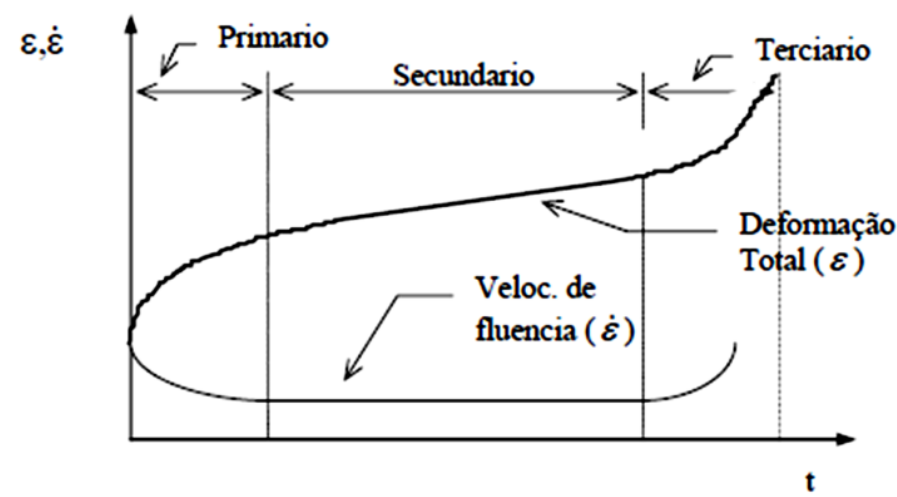

Figura 3.1 - Estágios da fluência

Fuenkajorn (1988) afirma que as leis constitutivas para retratar o comportamento da fluência podem ser agrupadas em três distintas categorias: modelos reológicos, leis empíricas e modelos de teoria física (formulados a partir da teoria discordâncias). Fuenkajorn (1988) foca em estudos na reologia do sal e mostra que modelos elástico-viscoplásticos são os que melhor se adaptam ao comportamento do sal uma vez que as constantes do modelo tomam valores coerentes com a física do problema e apresentam uma baixa dispersão quando comparados com modelos viscoelásticos. Contudo, o autor identifica dificuldades ao utilizar estes modelos porque a resposta às deformações térmicas é difícil de implementar e os modelos só caracterizam o sal para um pequeno intervalo de tensões. Assim, a comunidade científica e indústria têm utilizado com maior frequência as relações empíricas e modelos de teoria física para retratar constitutivamente o material sal. Entre as diversas formulações, pode-se destacar a Lei de Potência (empírica) e Duplo Mecanismo (teoria física). Estas teorias são amplamente utilizadas tal como apresentado em Costa (1984). Fuenkajorn (1988) afirma que a Lei de Potência é adequada para simular a fluência primária e a de Duplo Mecanismo para a fluência secundária.

Firme et al. (2014) chega também às conclusões Fuenkajorn (1988). Os autores apresentam uma comparação de três diferentes relações empíricas para simular a fluência na rocha salina, a Lei de Potência, Duplo Mecanismo e Multi Mecanismo. Concluem que, embora o modelo de Multi Mecanismo seja o mais concordante com os valores experimentais, o modelo de Duplo Mecanismo (fase secundária) apresenta bons resultados a longo prazo e a Lei de Potência (fluência 
primária) apresenta bons resultados para o curto prazo. Assim, a formulação híbrida apresentada neste trabalho tem como objetivo tirar partido do melhor destas últimas duas formulações.

\subsection{1.}

\section{Lei de Potência}

A lei de potência utiliza três constantes empíricas $n, m$ e $v$ que relacionam as grandezas físicas de tensão, temperatura e tempo com a deformação.

$$
\varepsilon(t)=A \sigma_{e q}{ }^{n} t^{m} T^{v}
$$

Os parâmetros empíricos utilizados para a Lei de Potência são retirados do trabalho de Lomenick \& Bradshaw (1969) apud Firme et al. (2014), apresentados na Tabela 3.2.

Tabela 3.2 - Parâmetros da Lei de Potência adotados para a halita brasileira

\begin{tabular}{clc}
\hline Caractere & \multicolumn{1}{c}{ Descrição } & Valor \\
\hline A & Multiplicador da lei da potência & $3,40029\left(10^{-50}\right)$ \\
$\mathrm{n}(\mathrm{Pa})$ & Potência relacionada com a tensão & 3,0 \\
$\mathrm{~m}(\mathrm{~s})$ & Potência relacionada com o tempo & 0,3 \\
$\mathrm{v}(\mathrm{K})$ & Potência relacionada com a temperatura & 9,5 \\
\hline
\end{tabular}

Fonte: Lomenick \& Bradshaw (1969) apud Firme et al. (2014)

\subsection{2.}

\section{Lei de Duplo Mecanismo}

Para a caracterização da fluência na halita brasileira, Costa et al. (2005) chegam à conclusão que a lei de Duplo Mecanismo é uma lei apropriada para a fase estacionária. A taxa de deformação é caracterizada pela seguinte equação.

$$
\dot{\varepsilon}=\dot{\varepsilon}_{0} \exp \left(\frac{Q}{R T_{0}}-\frac{Q}{R T}\right)\left(\frac{\sigma_{e q}}{\sigma_{0}}\right)^{n}
$$

Os parâmetros com base experimental adotados para a lei de Duplo Mecanismo para a halita brasileira estão presentes na seguinte tabela. 
Tabela 3.3 - Parâmetros da lei de Duplo Mecanismo adotados para a halita brasileira

\begin{tabular}{ccc}
\hline Caractere/unidade & Descrição & Valor \\
\hline $\mathbf{Q}(\mathrm{kcal} / \mathrm{mol})$ & Energia de ativação de ambos os mecanismos & 12,0 \\
$\mathbf{R}(\mathrm{kcal} / \mathrm{mol} . \mathrm{K})$ & Constante universal dos gases & $1,9858\left(10^{-3}\right)$ \\
$\boldsymbol{\sigma}_{\mathbf{0}}(\mathrm{kPa})$ & Tensão de mudança de mecanismo (Limite de Prandtl) & 9910,0 \\
$\dot{\boldsymbol{\varepsilon}}_{\mathbf{0}}\left(\mathrm{h}^{-1}\right)$ & Taxa de deformação de mudança de mecanismo & $1,888\left(10^{-6}\right)$ \\
$\mathbf{T}_{\mathbf{0}}\left({ }^{\circ} \mathrm{C}\right)$ & Temperatura de mudança de mecanismo & 86,0 \\
$\mathbf{n}_{\mathbf{1}}$ & Expoente de tensão para o deslizamento de discordâncias & 3,36 \\
$\mathbf{n}_{\mathbf{2}}$ & Expoente de tensão para a solubilização por pressão & 7,55 \\
\hline
\end{tabular}

Fonte: Poiatre Jr. (2012)

\subsection{3.}

\section{Formulação Híbrida}

Como referido anteriormente, verifica-se que a fluência primária é descrita com maior detalhe pela Lei da Potência enquanto que a resposta do Duplo Mecanismo apresenta conformidade com a fluência secundária. Desta forma, a formulação Híbrida junta estas duas formulações. Quando o incremento de deformação dada pela Lei da Potência é superior à do Duplo Mecanismo, essa deformação é a considerada e vice-versa. Foi então elaborada uma sub-rotina CREEP com as duas formulações. As formulações dos modelos constitutivos foram cedidas por Pedro A. L. P. Firme do grupo de geomecânica computacional do Tecgraf.

Para validar a formulação, foram replicados numericamente no programa de elementos finitos ABAQUS os ensaios triaxiais de fluência realizados por Costa et al. (2005). Esta replicação numérica foi também feita por Firme et al. (2014). O corpo de prova cilíndrico de halita brasileira tem 176 milímetros de altura e raio de 44 milímetros. Os parâmetros elásticos utilizados foram os apresentados na Tabela 3.4 .

Tabela 3.4 - Parâmetros elásticos adotados para a halita brasileira

\begin{tabular}{clc}
\hline Caractere/unidade & \multicolumn{1}{c}{ Descrição } & Valor \\
\hline $\mathrm{E}(\mathrm{GPa})$ & Módulo de elasticidade (ou Young) & 25,37 \\
$v$ (adim.) & Coeficiente de Poisson & 0,36 \\
\hline
\end{tabular}

Fonte: Firme et al. (2014) 
O modelo de elementos finitos reproduz um quarto do corpo de provas de sal da halita brasileira. Foram utilizados elementos 200 elementos CAX4 para definir o modelo axissimétrico. A Figura 3.2 mostra uma esquematização do modelo numérico e do modelo real.

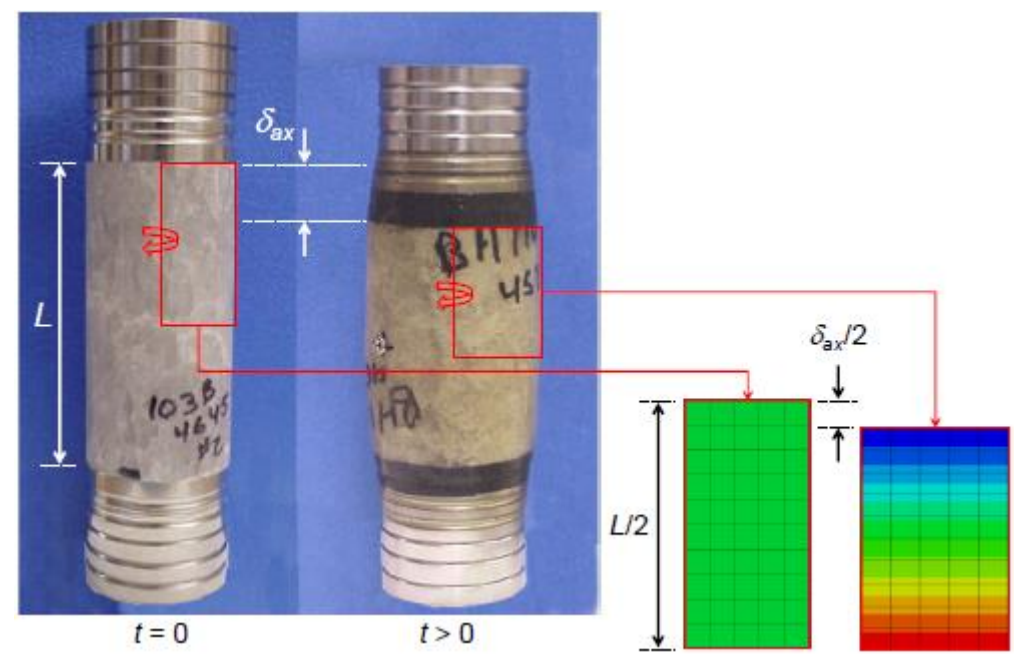

Figura 3.2 - Esquematização do modelo numérico em relação ao modelo experimental Fonte: Firme (2013)

No eixo de axissimetrico é definida a restrição simétrica $X S Y M M$ e a base do modelo foi restringido na direção vertical. Em consenso com o experimental e como esquematizado na Figura 3.3, o modelo numérico foi sujeito a uma tensão triaxial de $10 \mathrm{MPa}$ (Figura 3.3b). A seguir, uma tensão vertical de mais $4 \mathrm{MPa}$ foi aplicada no topo do modelo (Figura 3.3c).

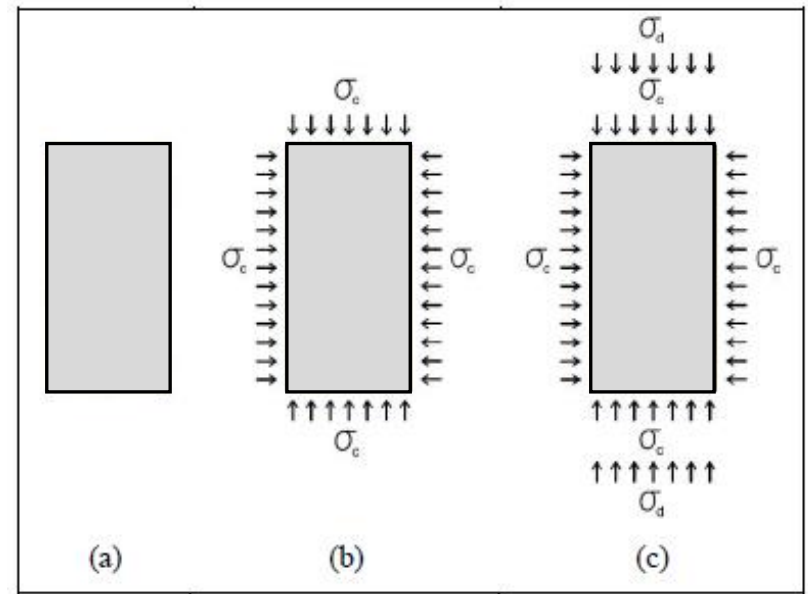

Figura 3.3 - Esquematização do ensaio triaxial Fonte: Firme (2013)

A Figura 3.4 mostra o comparativo entre a Lei de Multi e Duplo Mecanismo, lei Híbrida, Lei de Potência e a análise experimental. As conclusões apresentadas no início do presente capítulo são então enxergadas. A lei da potência é próxima do ensaio experimental no início da fluência. Já a lei de Duplo Mecanismo, tende a 
aproximar-se da solução experimental a longo prazo. A formulação Híbrida apresentada neste trabalho segue quase que fielmente o modelo experimental pelo que podemos dar este modelo como confiável e aplicável. Além do mais, esta formulação resulta em valores de deformação próximos aos da Lei de Multi Mecanismo. Contudo, a formulação Híbrida necessita de menor número de parâmetros e é de mais fácil implementação, o que vigora as suas vantagens face ao Multi Mecanismo.

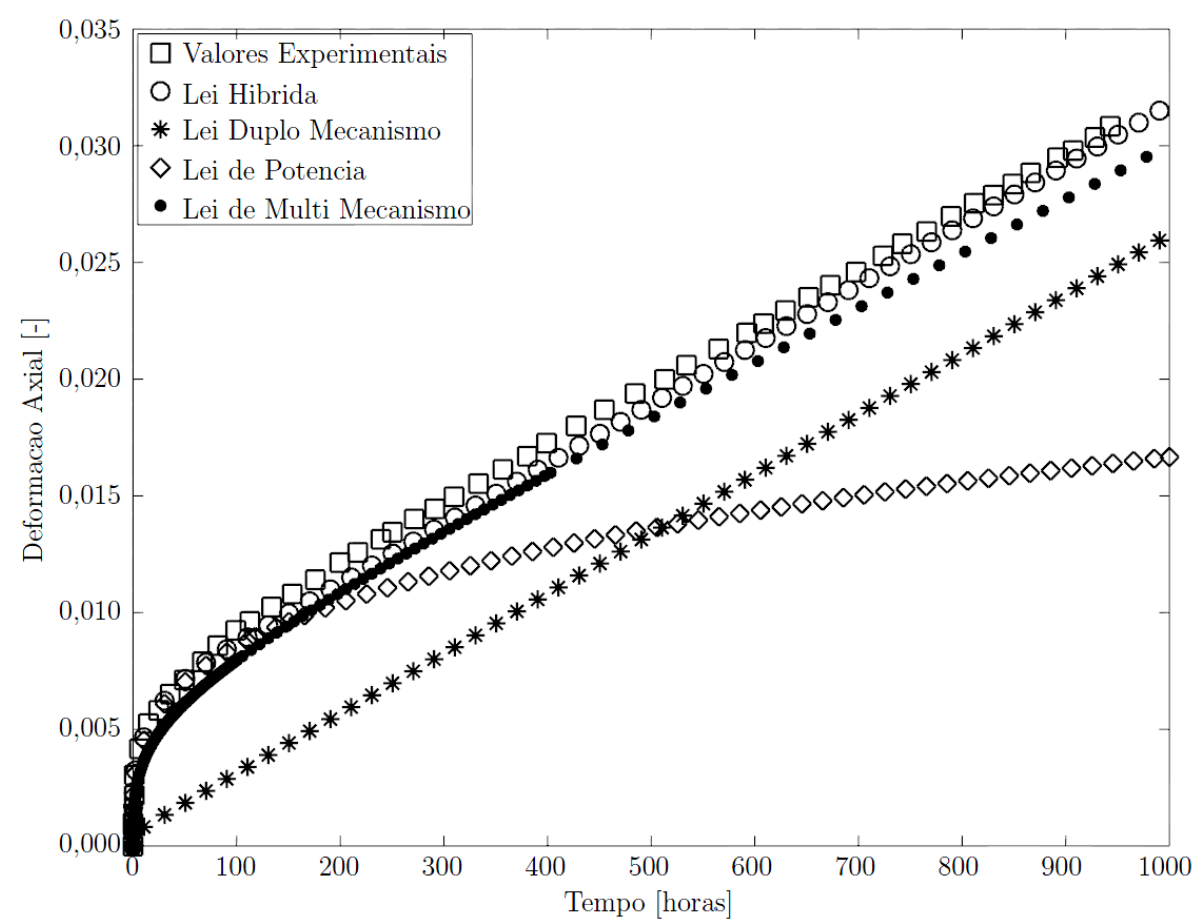

Figura 3.4 - Comparativo entre as várias formulações de fluência e o ensaio experimental

\section{3.}

\section{A pasta de cimento}

A modelagem da pasta de cimento no presente trabalho tem em conta a análise do mesmo em 2 diferentes estados, líquido e solidificado. $\mathrm{O}$ efeito da pasta de cimento no estado líquido no poço é simulado através da aplicação de cargas nas paredes do poço, equivalentes à pressão hidrostática da pasta. $\mathrm{O}$ estado pastoso/solidificado é simulado de duas formas. Primeiro, como um material elástico com o aumento do módulo de elasticidade no tempo. Em seguida, para além da evolução das propriedades elásticas, também se considerou o critério elastoplástico de Drucker Prager com as propriedades que definem a envolvente de ruptura incrementáveis com o tempo. 


\subsection{1.}

\section{A pasta de cimento no estado líquido}

A pasta de cimento exibe uma pressão hidrostática que dependente da profundidade e do peso específico da coluna na cota em análise. Como apresentado anteriormente na seção 2.3.1.1, depois da pasta de cimento ser bombeada para o espaço entre o revestimento metálico e a formação rochosa, esta sofre uma diminuição de pressão. Essa diminuição é explicada pela retração autógena durante a formação de esqueleto da pasta de cimento, a perda de fluídos e tensões cisalhantes decorrentes do contato entre a pasta, rocha e revestimento (Static Gel Strength ou SGS). A Figura 2.7 mostra essa diminuição com o padrão de uma exponencial que se inicia com a pressão correspondente ao peso da pasta cimentícia na cota simulada. Quando a pasta de cimento forma o esqueleto sólido, a retração externa tem um efeito menos acentuado e a pressão hidrostática estabiliza para valores próximos aos do peso do fluído de perfuração. Essa diminuição acontece em cerca de 250 minutos o que corresponde a cerca de 4 horas. Estes valores estão de acordo o intervalo de tempo onde ocorre a retração autógena na formação do esqueleto, no estado líquido como apresentado na Figura 2.9.

\subsection{2. \\ Metodologia para simular os efeitos mecânicos da solidificação do cimento}

Existem duas situações na natureza para as quais a pasta de cimento exibe variação das propriedades mecânicas, a solidificação e a deterioração. A solidificação é caracterizada pelo aumento das propriedades mecânicas ao longo do tempo enquanto que a deterioração é qualificada como a diminuição das propriedades mecânicas. Um dos primeiros trabalhos que distingue as formulações constitutivas foi apresentado por Bazant (1979), que chega às diferentes leis através de princípios termodinâmicos. A equação (3.3) representa a relação constitutiva entre deformação e tensões uniaxial para o caso da solidificação e a relação uniaxial (3.4) para a deterioração ao longo do tempo para materiais elásticos. O autor afirma categoricamente que as formulações devem ser usadas em conformidade com a evolução das propriedades do material no tempo, isto é, tendo em conta o sinal da derivada da evolução do modulo de elasticidade no tempo. Bazant (1979) reconhece 
que o segundo termo da equação (3.4) se distingue como a dissipação de energia por perda de rigidez do material.

$$
\begin{gathered}
\text { Solidificação } \rightarrow \dot{\varepsilon}(t)=\dot{\sigma}(t) / E(t) \\
\text { Deterioração } \rightarrow \dot{\varepsilon}(t)=\frac{\partial[\sigma(t) / E(t)]}{\partial t}=\frac{\dot{\sigma}(t)}{E(t)}-\frac{\sigma(t) \cdot \dot{E}(t)}{E^{2}(t)}
\end{gathered}
$$

Oliveira \& Creus (2004) chegam aos resultados de Bazant (1979) partindo da representação das deformações por meio de integrais hereditários com $D(t, \tau)$ (função de fluência ao longo do tempo). Ao definir o termo $C(t, \tau)=0$ os efeitos visco diferidos no tempo são extintos e o material comporta-se como elástico.

A relação (3.5) representa a solidificação.

$$
\begin{aligned}
\varepsilon(t)=\int_{\tau_{0}}^{t} D(t, \tau) \dot{\sigma}(\tau) d \tau & =\int_{\tau_{0}}^{t}(\frac{1}{\boldsymbol{E}(\boldsymbol{\tau})}+\underbrace{C(t, \tau)}_{0}) \dot{\sigma}(\tau) d \tau \\
\text { Solidificação } & \rightarrow \dot{\varepsilon}(t)=\dot{\sigma}(t) / E(t)
\end{aligned}
$$

Note que a função constitutiva $E(\tau)$ depende da variável tempo $\tau$, que é uma variável temporal que define o período de carregamento no tempo.

A relação (3.6) representa a deterioração.

$$
\begin{gathered}
\varepsilon(t)=\int_{\tau_{0}}^{t} D(t, \tau) \dot{\sigma}(\tau) d \tau=\int_{\tau_{0}}^{t}(\frac{1}{\boldsymbol{E}(\boldsymbol{t})}+\underbrace{C(t, \tau)}_{0}) \dot{\sigma}(\tau) d \tau \\
\text { Deterioração } \rightarrow \dot{\varepsilon}(t)=\frac{\partial\left(\frac{1}{E(t)} \cdot \int_{\tau_{0}}^{t} \dot{\sigma}(\tau) d \tau\right)}{\partial t}=\frac{\dot{\sigma}(t)}{E(t)}-\frac{\sigma(t) \cdot \dot{E}(t)}{E^{2}(t)}
\end{gathered}
$$

$\mathrm{Na}$ deterioração, a função constitutiva $E(t)$ depende da variável tempo $t$, que pode ser enxergada como a variável de tempo total, que independe do início cronológico do carregamento.

Aqui é que reside a diferença entre as duas formulações. Para explicar a diferença, Eierle \& Schikora (1999) assemelham a pasta de cimento a um material do quotidiano, a manteiga. Existe um paralelismo entre os materiais quando solidificados ou deteriorados. Ao aquecer manteiga, esta deteriora-se por redução das propriedades mecânicas e conclui-se que o operador constitutivo não deve ser só dependente da variação de tensão aplicada, mas também da variação da evolução das propriedades mecânicas. Assim, mesmo que não haja variação de tensão, o material pode sofrer deformações única e exclusivamente por alteração das propriedades mecânicas - desta forma, considera-se o operador constitutivo função do tempo $t$. Por outro lado, ao esfriar a manteiga, a mesma não se deteriora. A magnitude da deformação depende unicamente do momento cronológico em que 
existe uma variação de tensão - desta forma considera-se o operador constitutivo função do tempo $\tau$.

Resolvendo as equações diferenciais numericamente de forma implícita presentes em (3.3) e (3.4) ou (3.5) e (3.6), chegam-se às formulações apresentadas em (3.7) e (3.8).

$$
\begin{gathered}
\text { Solidificação } \rightarrow \sigma_{n+1}=E_{n+1} \cdot \Delta \varepsilon+\sigma_{n} \\
\text { Deterioração } \rightarrow \sigma_{n+1}=\left(E_{n+1} \cdot \Delta \varepsilon+\sigma_{n}\right) \frac{E_{n+1}}{E_{n}}
\end{gathered}
$$

Como apresentado já na seção 2.3.1.3, a literatura mostra que as reações de hidratação podem ser simuladas por um incremento das propriedades mecânicas ao longo do tempo. Assim sendo, está-se perante um caso clássico de solidificação e a formulação candidata a ser utilizada é a apresentada em (3.7).

Para alterar as propriedades mecânicas ao longo do tempo, o programa ABAQUS tem implementada a seguinte relação em que o estado de tensão depende da variação do modulo de elasticidade.

$$
\mathrm{ABAQUS} \rightarrow \sigma_{n+1}=\underbrace{\sigma_{n}+E_{n+1} \cdot \Delta \varepsilon}_{\text {Solidificação }}-E_{n+1} \cdot \underbrace{\left[\frac{\sigma_{n}}{E_{n+1}}-\frac{\sigma_{n}}{E_{n}}\right]}_{\Delta \varepsilon^{\text {th }}}
$$

A formulação (3.10) é originalmente aplicada a variações de coeficientes térmicos e variações de temperatura $\left(\Delta \varepsilon^{t h}\right)$ em materiais termicamente expansivos e adaptado pelo programa ABAQUS para a variação das propriedades mecânicas. Observa-se que a parcela referente ao incremento de tensão por variação de deformação é idêntica à primeira parcela de (3.7).

É apresentado na Figura 3.5 um simples exemplo com recurso ao programa de elementos finitos ABAQUS com o intuito de comparar as formulações (3.7) e (3.10). O caso que aplica a formulação do ABAQUS (caso A) utiliza as próprias ferramentas do programa. No segundo caso, a formulação que simula a solidificação (caso S) é implementada de duas formas: através da formulação (3.7) com recurso à ferramenta UMAT; e com a equação incremental (3.10) com a correção das tensões para o instante que as propriedades mecânicas do material são alteradas para anular o efeito da parcela $\Delta \varepsilon^{\text {th }}$. Como esperado, as duas estratégias revelam-se idênticas.

Ambas as análises A e S são feitas com um estado de tensão inicial prescrito e variação de modulo de elasticidade para entender as repercussões dessa alteração. As etapas são apresentadas na Figura 3.5, onde se usam elementos de estado plano 
de deformação, quadrados de lado $1 \mathrm{~m}$, com quatro nós e integração reduzida (um ponto de Gauss). No tempo 0 h até 1 h, o elemento está restringido em todos os nós com módulo de elasticidade de $1 \mathrm{~Pa}$. Esta fase é apelidada de fase geostática. No tempo de $1 \mathrm{~h}$ a 1,6h, apelidado de fase E1, não existe restrição horizontal nos nós 2 e 3 e é aplicada uma força de $0,5 \mathrm{~N}$ na borda entre os nós 2 e 3. No tempo 1,6h, o módulo de elasticidade é alterado de 1 Pa para 2 Pa e a carga é retirada da análise.

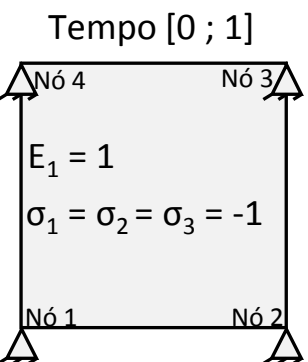

a)

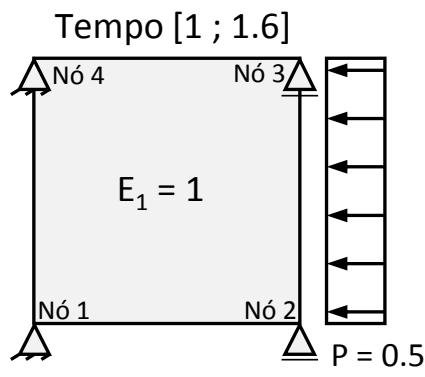

b)
Tempo $[1.6 ; 2.2]$

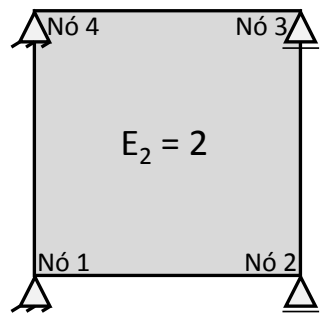

c)

Figura 3.5 - a) tempo [0h;1h] - tensão inicial hidrostática e módulo de elasticidade unitário b) tempo [1h;1,6h] - liberação da restrição em x do nó 2 e 3 e aplicação de carga de magnitude $0.5 \mathrm{~Pa}$ na face correspondente c) tempo [1,6h;2,2h] - mudança de material de $\mathrm{E}_{1}$ para $\mathrm{E}_{2}$

A Figura 3.6 mostra os resultados evolução das propriedades mecânicas obtida com a formulação disponível no ABAQUS - caso A.

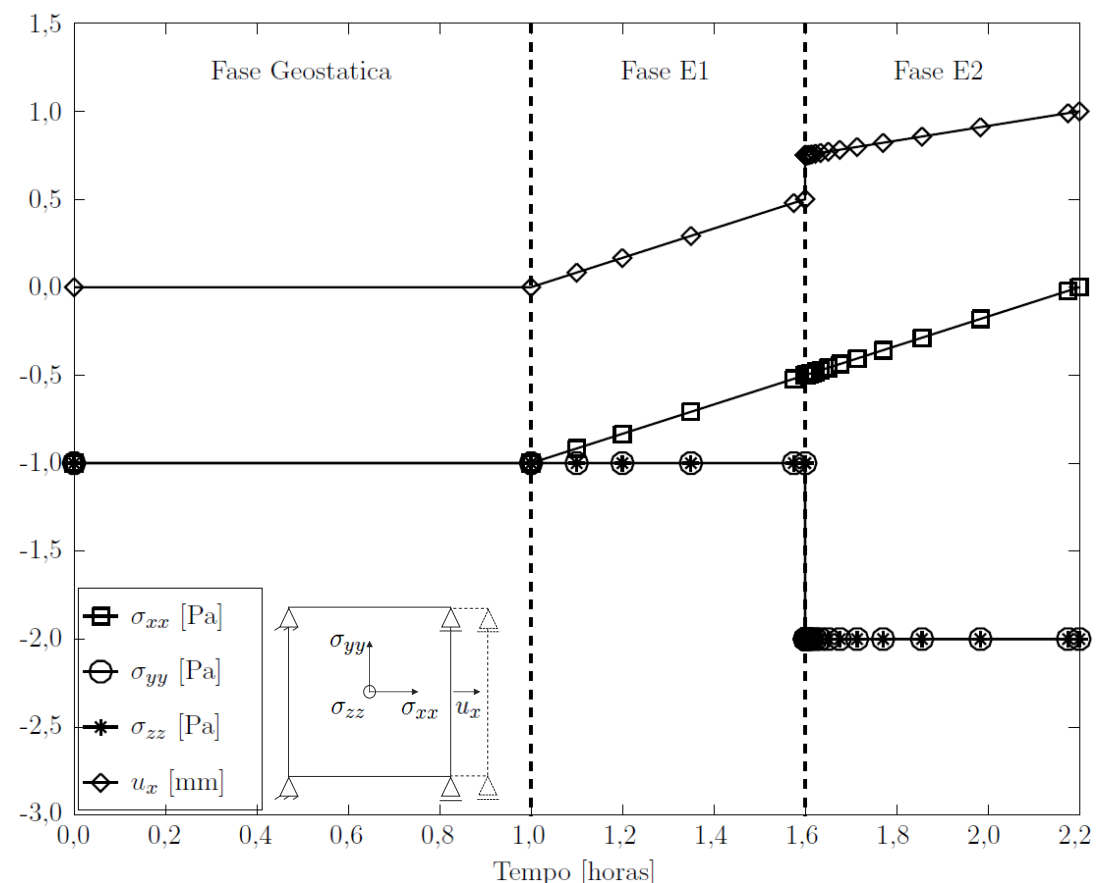

Figura 3.6 - Tensão medida num ponto de Gauss e deslocamento x do nó 2 para a análise com mudança de estado de tensão de acordo com as propriedades mecânicas

Analisando os resultados, percebe-se que a mudança de material faz com que o estado de tensão nas direções restringidas aumenta proporcionalmente ao quociente entre os módulos de elasticidade, $\mathrm{E}_{\mathrm{n}+1} / \mathrm{E}_{0}$, às 1,6 horas. $\mathrm{Na}$ borda onde $\mathrm{o}$ 
deslocamento não é restrito, o estado de tensão é prescrito e o incremento de deformação para as 1,6 horas se deve à parcela $\Delta \varepsilon^{t h}$.

Estes resultados não vão de encontro ao pretendido para a modelagem da solidificação da pasta ao longo do tempo. Depois de definido o estado líquido, é espectável que o estado de tensão da pasta de cimento no poço seja aproximadamente constante. Além do mais, na direção zz não faz sentido haver um acréscimo de tensão. Outro ponto de manifesta desconformidade entre a modelação e a realidade é o fato do estado de tensão passar a depender da magnitude do novo módulo de elasticidade.

Assim, o estado de tensão e o campo de deformações da pasta de cimento não deverá mudar com a mudança de material. A Figura 3.7 mostra o desenvolvimento das tensões e deformações para esta metodologia - caso S.

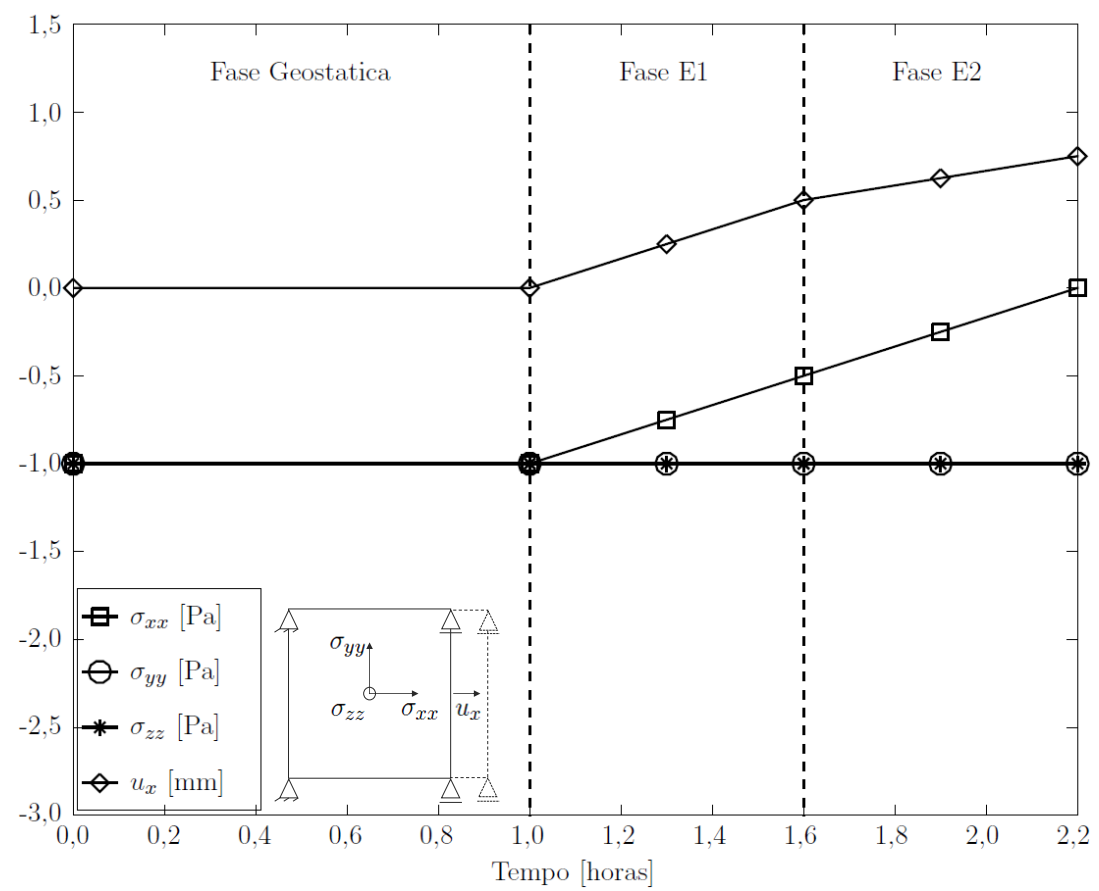

Figura 3.7 - Tensão medida num ponto de Gauss e deslocamento x do nó 2 para a análise

Conclui-se que os resultados do último procedimento estão de acordo com o esperado. As tensões restringidas não foram afetadas pela mudança do módulo de elasticidade e a tensão no eixo xx tende para zero como esperado. O deslocamento tem um declive menos acentuado na fase E2 que na fase E1 devido ao aumento da rigidez do elemento neste mesmo período. 


\subsection{3. \\ Modelos constitutivos elastoplásticos para simulação da pasta de cimento}

Para simular e aproximar o comportamento da pasta de cimento ao real, podese implementar modelos constitutivos elastoplásticos com dano. Baret et al. (1998) comentam que a indústria petroleira pouco fez até então para quantificar o dano em função das condições do fundo do poço. O dano verificado na bainha é originado pela variação das condições no fundo do poço. Essas variações são repercussões de vários procedimentos pelo qual o poço passa como a sua construção, a perfuração do revestimento metálico, fraturamento hidráulico e produção do reservatório. Estes procedimentos causam variação de pressão e temperatura que levam ao dano da pasta cimentícia.

Existem vários exemplos na literatura que simularam o dano nas suas modelagens, como por exemplo Bosma et al. (1999). Os autores simularam a pasta de cimento com um modelo constitutivo que combina fratura distribuída (smeared cracking) para a tração e um modelo plástico à compressão de Mohr Coulomb. Também comentam que modelos com fratura frágil (brittle crack), fratura com amolecimento linear (cracking with linear softening) e vários outros como uma combinação de limite de resistência à tração (tension cut-off) seriam válidos para a análise. Ravi \& Bosma (2005) seguiram o mesmo padrão, pelo que utilizaram como modelo constitutivo um modelo com fratura distribuída à tração e plasticidade segundo o critério de Mohr Coulomb à compressão.

Para retratar o comportamento da pasta de cimento, o programa comercial ABAQUS conta com diferentes modelos constitutivos como Smeared Cracking (SC), Other Quase-Brittle Materials (OQBM) ou Concrete Damaged Plasticity (CDP). Os dois primeiros modelos são semelhantes. A única diferença assinalável é que o OQBM define a pasta de cimento como elástico à compressão enquanto que o SC define a pasta de cimento como elásto-plástico com encruamento. O CDP é o único modelo que simula o concreto no ABAQUS levando em conta a perda de rigidez com o dano e contempla duas variáveis de dano, uma para a tração e outra para a compressão.

Contudo, Philippacopoulos \& Berndt (2001) ensaiam corpos de prova de pastas de cimento classe $\mathrm{G}$ e concluem que, para a temperatura ambiente, o ensaio uniaxial à compressão exibe um amolecimento pós-pico. Porém, ao curar os corpos 
de prova em altas temperaturas, verifica-se que os corpos de prova apresentam um menor pós-pico e este comportamento perde ainda mais preponderância para carregamentos triaxiais. Assim, o uso de modelos como o SC seriam uma melhor escolha para avaliar a pasta de cimento no contexto petrolífero. Além do mais, a pasta de cimento neste contexto tem a função primária de isolante e não estrutural, pelo que a avaliação da perda de rigidez a ações cíclicas não é propriamente objetivo de análise para as pastas em poços de petróleo.

Embora a literatura dê exemplos de modelos sofisticados para a avaliação da integridade do cimento, este estudo contempla como primeira aproximação a utilização dos modelos de Mohr Coulomb (M-C) e Drucker Prager (D-P). A utilização destes modelos procura esclarecer se a modelagem do aumento das propriedades mecânicas necessita de modelos mais complexos.

\subsubsection{1.}

\section{Mohr Coulomb e Drucker Prager}

A consideração das deformações plásticas de materiais como rochas, concreto ou pastas de cimento têm obrigatoriamente que ser simuladas por modelos com sensibilidade a estados hidrostáticos. O modelo de M-C e D-P são amplamente utilizados para o contexto descrito. $\mathrm{O}$ aumento da resistência à compressão devido à pressão confinante e a ruptura por tração diferenciam estes de modelos como Von Mises e Tresca. Mais ainda, estes são modelos simples pois dependem unicamente de duas constantes.

Jiand \& Xie (2011) elaboram um estudo sobre os dois critérios. A equação de M-C escrita em termos dos invariantes é a seguinte:

$$
p \cdot \sin (\varphi)+\sqrt{J_{2}}\left(\cos (\theta)-\sin (\theta) \cdot \frac{\sin (\varphi)}{\sqrt{3}}\right)-c \cdot \cos (\varphi)=0
$$

onde $\varphi$ e c são o ângulo de atrito e a coesão do material, $p$ é a pressão média hidrostática e $\sqrt{J_{2}}$ é a tensão desviadora ou tensão de Von Mises. O símbolo $\theta$ representa o ângulo de Lode. A equação no plano desviador apresenta uma forma hexagonal com 3 vértices mais distanciados do eixo hidrostático (Meridianos de Compressão) e outros 3 vértices mais próximos deste mesmo eixo (Meridianos de Tração).

O critério de Drucker Prager simplifica o critério de M-C . A equação em termos dos invariantes é escrita da seguinte forma: 


$$
\sqrt{J_{2}}-3 \alpha \cdot p-k=0
$$

Observa-se que a equação não tem uma dependência do ângulo de Lode visto que no plano desviador o raio, ou seja, a tensão de von Mises, é constante. Consequentemente, todos os meridianos deste modelo são iguais. Os parâmetros $\alpha$ e $k$ representam a inclinação do meridiano no plano p-q. Quando D-P é definido por um dos meridianos de M-C, a representação desse meridiano será coincidente para os dois modelos (Figura 3.8).

Jiand \& Xie (2011) apresentam duas debilidades do modelo M-C para o problema em questão. Em primeiro lugar, este não contabiliza a tensão principal intermediaria $\left(\sigma_{2}\right)$ na definição da envolvente de ruptura. Portanto, omite o acréscimo de tensão de resistência à compressão para o estado biaxial. Já o modelo de D-P contabiliza esse efeito. Em segundo lugar, nos vértices do hexágono, a função de plastificação apresenta singularidades.

Jiand \& Xie (2011) apresentam quatro possibilidades para os valores de $\alpha$ e $k$ de D-P coincidente com meridianos da superfície de M-C: Meridiano de Compressão (D-P1), Cortante (D-P2) e Tração (D-P3). A última estimativa das constantes é feita para que D-P4 seja circunscrito pela função de M-C.

\begin{tabular}{ccc} 
Tabela 3.5 - Parâmetros que relacionam os critérios D-P com M-C \\
\hline Caso & $\boldsymbol{\alpha}$ & $\mathbf{k}$ \\
\hline D-P1 & $-\frac{2 \sqrt{3} \operatorname{sen}(\varphi)}{3-\operatorname{sen}(\varphi)}$ & $-\frac{2 \sqrt{3} \cdot \operatorname{coc} \cos (\varphi)}{3-\operatorname{sen}(\varphi)}$ \\
D-P2 & $-\operatorname{sen}(\varphi)$ & c. $\cos (\varphi)$ \\
D-P3 & $\frac{-2 \sqrt{3} \operatorname{sen}(\varphi)}{3+\operatorname{sen}(\varphi)}$ & $\frac{2 \sqrt{3} \cdot \operatorname{coc} \cos (\varphi)}{3+\operatorname{sen}(\varphi)}$ \\
D-P4 & $-\frac{\sqrt{3} \operatorname{sen}(\varphi)}{\sqrt{3-\operatorname{sen}^{2}(\varphi)}}$ & $\frac{\sqrt{3} \cdot \operatorname{coc} \cos (\varphi)}{\sqrt{3+\operatorname{sen}^{2}(\varphi)}}$
\end{tabular}

Fonte: Jiand \& Xie (2011)

A Figura 3.8 mostra para que ângulos de Lode no critério de M-C a adaptação do D-P foi feita. 

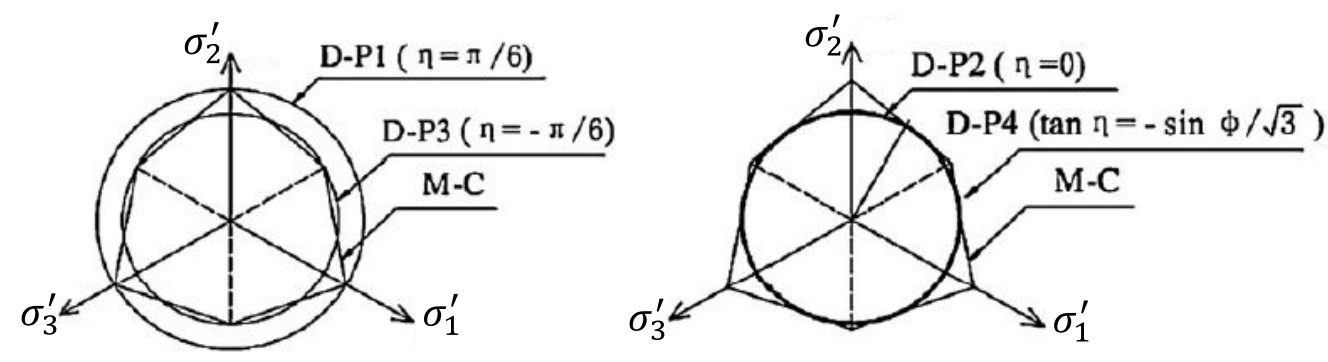

Figura 3.8 - Comparação dos quatro D-P e do M-C plano desviatório Fonte: Jiand \& Xie (2011)

Jiand \& Xie (2011) concluem que os vários modelos de D-P tanto podem dar resultados concordantes como disparares dos experimentos. Al-Ajmi \& Zimmerman (2006) verificam que calibrando a curva de D-P com valores do verdadeiro ensaio triaxial $\left(\sigma_{3}=\sigma_{2}\right)$, o critério tende a sobrestimar os resultados de resistência para ensaios poliaxiais $\left(\sigma_{3} \geq \sigma_{2} \geq \sigma_{1}\right)$ porque o critério dá a mesma contribuição para $\sigma_{2}$ e $\sigma_{3}$. Contudo, e em consenso com o concluindo por Jiand \& Xie (2011), este critério mostrou ser uma boa aproximação para certos casos. Ajmi \& Zimmerman (2006) verificam também que critério de M-C valores da resistência da rocha ensaios poliaxiais por não contabilizar na formulação o valor da $2^{\mathrm{a}}$ tensão principal e que representa apenas os casos para $\sigma_{3}=\sigma_{2}$ ou $\sigma_{1}=\sigma_{2}$. Em outras palavras, representa apenas os valores coincidentes para o Meridiano de compressão e tração.

Dito isto, pode-se então esperar que os valores poliaxiais para o meridiano de compressão para o caso D-P1 seriam coincidentes com os experimentais no meridiano de compressão. Porém, o critério D-P1 sobrestimaria os resultados experimentais à medida que se afasta do meridiano de compressão e se aproxima do meridiano de tração. Neste meridiano valor do erro seria máximo.

Para o entendimento das superfícies de escoamento de M-C e D-P para o caso do cimento classe $\mathrm{G}$, plotaram-se as superfícies de escoamento para os 28 dias com as propriedades apresentadas na Figura 2.11 e Figura 2.12 no plano p-q. As Figura 3.9 e Figura 3.10 apresentam 3 meridianos plotados com recurso à equação (3.10). 


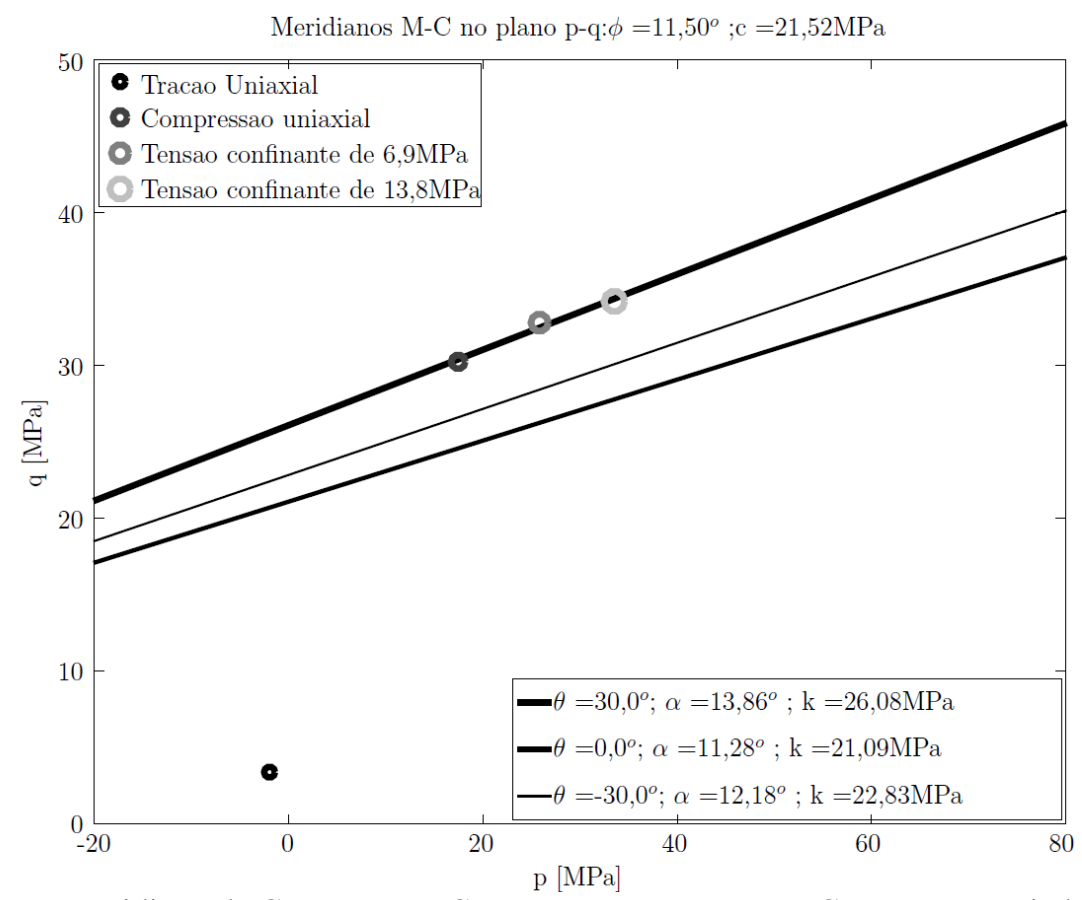

Figura 3.9 - Meridiano de Compressão, Cortante e Tração para M-C para as propriedades do cimento aos 28 dias para os ensaios de compressão confinados

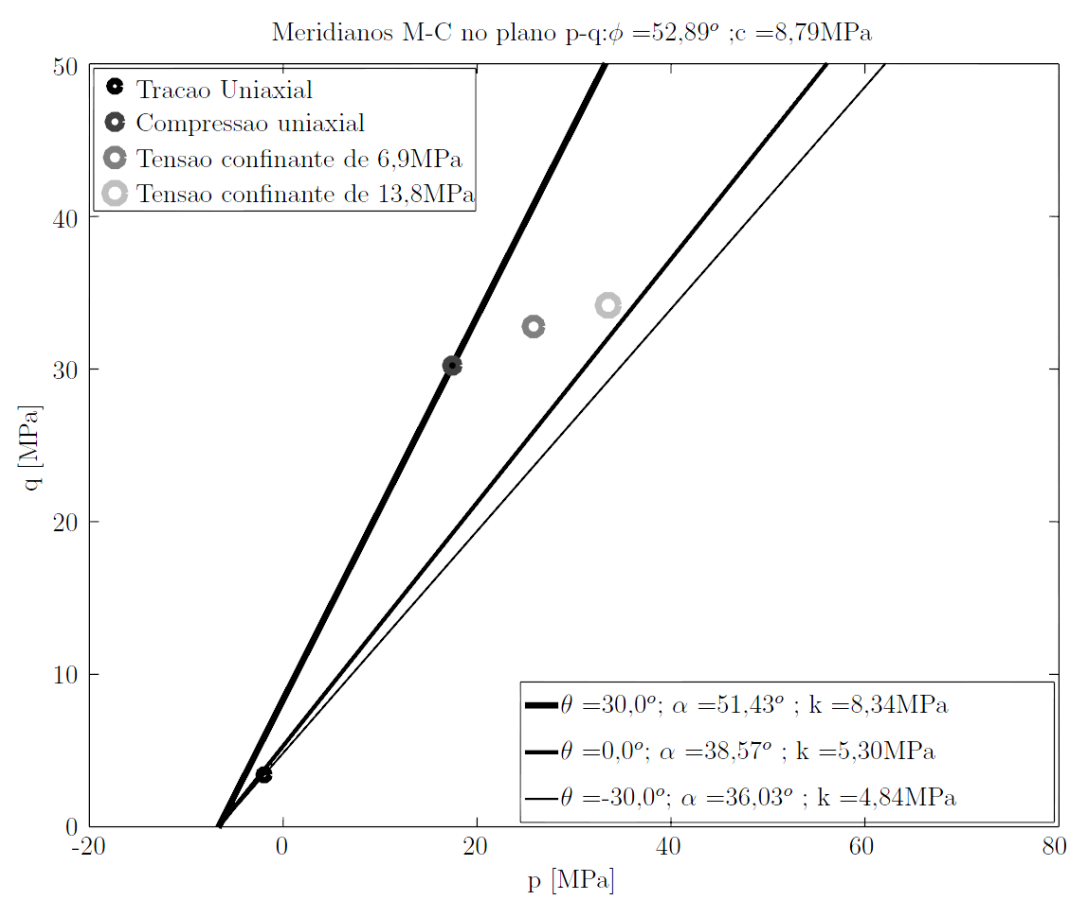

Figura 3.10 - Meridiano de Compressão, Cortante e Tração para M-C para as propriedades medidas aos 28 dias para os ensaios não confinados

Conclui-se que os valores de declive e de ordenada na origem de cada meridiano são equivalentes aos valores dados pela fórmula Tabela 3.5 para D-P1, D-P2 e D-P3. Os pontos plotados nas figuras representam o estado de tensão de cada círculo de Mohr no plano p-q. Observa-se que, para ambas as figuras, os pontos coincidem com a envoltória de ruptura. 
Conclui-se também que, para que a função de plastificação se adeque aos ensaios de compressão e aos ensaios não confinados, é necessário que seja uma função ajustada aos pontos de ruptura dos 4 ensaios. Assim, o declive deixa de ser constante e passa a variar com a variável P ou q.

O critério D-P1 será o utilizado nos capítulos subsequentes. Uma vez que no contexto de óleo e gás, o cimento começa as reações de hidratação com um estado de tensão hidrostático à compressão, achou-se sensato utilizar o caso D-P1 na modelagem.

A Tabela 3.6 apresenta os valores de declive e ordenada na origem para o critério D-P1 ao longo do tempo tendo como base os valores de ângulo de atrito e coesão da Figura 2.11.

Tabela 3.6 - Aumento do declive e ordenada na origem para modelo D-P1 ao longo do tempo para ensaios à compressão

\begin{tabular}{ccc}
\hline Tempo [dias] & $\boldsymbol{\alpha}\left[{ }^{\circ}\right]$ & $\mathbf{k}[\mathrm{MPa}]$ \\
\hline 0,25 & 8,04 & 8,14 \\
0,58 & 11,13 & 15,08 \\
1 & 12,01 & 17,97 \\
3 & 12,82 & 21,16 \\
7 & 13,64 & 24,96 \\
14 & 13,89 & 26,26 \\
28 & 13,86 & 26,08 \\
\hline
\end{tabular}




\section{4 \\ Processo de construção do poço}

O capítulo 2 referencia a constituição química do cimento, método de contrução do poço e as causas gerais para perda de integridade a curto e longo prazo. O principal objetivo do estudo é definir uma análise que considere o histórial de construção do poço, desde o revestimento até os 28 dias de cura. Assim sendo, os efeitos a curto prazo são os contabilizados nesta análise.

Embora o problema real seja um problema 3D, simplificou-se a modelagem para o estado plano de deformção. A modelagem propriamente dita foi elaborada através de arquivos de entrada inp automatizados que necessitam de 8 parâmetros para definir a malha.

Dois casos de estudo são propostos com o intuito de analisar tensões, deformações e aplicabilidade dos modelos constitutivos apresentados no capítulo anterior.

O primeiro estudo de caso - Estudo de Caso 1 - tem o objetivo de comparar o modelo constitutivo Híbrido para o sal com o modelo constitutivo de Duplo Mecanismo e de Multi Mecaniscmo. Neste caso de estudo a pasta de cimento foi desconsiderada e os resultados do estudo comparados com resultados apresentados anteriormente na literatura por Fossum \& Fredrich (2007) e Firme et al. (2014). Além do mais, avaliou-se a aplicabilidade da Lei Híbrida no contexto de poços.

O segundo caso de estudo - Estudo de Caso 2 - é similar ao primeiro, mas com a pasta de cimento aplicada no anular entre o revestimento e formação rochosa. Neste segundo caso desconsidera-se a ovalização e avaliou-se o processo de perfuração, reconstrução, retração autógena para pasta na fase líquida e a evolução das propriedades mecânicas nos primeiros 28 dias. Numa primeira análise considerou-se o cimento elástico com uma evolução das propriedades mecânicas presentes no trabalho de Pfeifle et al. (2001), apresentados na Tabela 2.2. Os autores ensaiaram a pasta de cimento a $20^{\circ} \mathrm{C}$. Na segunda análise, considerou-se o cimento elasto-plástico com critério de Drucker Prager com o seu meridiano coinincidente com o meridiano de compressão de Mohr Coulomb - caso D-P1 apresentado na 
seção 3.3.3.1. As propriedades mecânicas do modelo evoluiram conforme os valores apresentados por Rocha (2015), apresentados na Tabela 2.3. Estes ensaios consideram a temperatura de $60^{\circ} \mathrm{C}$, temperatura esta que se apróxima às temperaturas medidas no pré-sal.

\section{1.}

\section{Estado plano de deformação vs modelo 3D}

Todos os modelos apresentados neste estudo são feitos com recurso a elementos Q4 num estado plano de deformação. Embora a estrutura real dum poço seja sempre uma estrutura 3D, Rodriguez et al. (2003) dizem que vários problemas 3D podem ser aproximados a problemas de duas dimensões. Nessa aproximação três diferentes considerações 2D podem ser escolhidas, estado plano de tensão, deformação ou axissimétrico. Para avaliação da integridade em poços de petróleo, o estado plano de deformação é o utilizado, uma vez que a simulação é feita em uma profundidade definida. Nessa cota, a premissa de que os delocamentos são nulos na dimensão perpendicular da seção é razoável. Gray et al. (2007) concluem que a tensão geoestática, que simula o peso das camadas até à cota de controle, é praticamente constante numa dada profundidade, o que valida a utilização do estado plano de deformação. Assim, o problema 3D é substituido por um problema 2D. Schreppers (2015) conclui que a análise 2D cobre a maior parte de todos os modos de ruptura observados na pasta de cimento. Afirma também que a grande desvantagem da modelagem $2 \mathrm{D}$ é de que apenas uma dada profundidade pode ser analisada por análise. Porém, a análise 2D é uma solução mais expedita que a 3D pelo menor esforço computacional necessário para a executar.

\section{2.}

\section{Automatização da malha}

O programa ABAQUS tem a plataforma gráfica que auxilia o utilizador na geração dos dados de processamento. Estes dados são armazenados no arquivo inp. A plataforma gráfica é bastante rígida a alterações de dimensões iniciais e geração de novas malhas aquando da modelagem terminada. Além do mais, ao definir o arquivo de entrada através da opção gráfica, os nós e os elementos são definidos individualmente, resultando num arquivo inp extenso e de difícil leitura. Outro 
aspecto é que o programa $\mathrm{ABAQUS} \mathrm{tem} \mathrm{comandos} \mathrm{que} \mathrm{não} \mathrm{são} \mathrm{contemplados} \mathrm{na}$ plataforma gráfica.

Assim, a geração manual do arquivo de entrada traz vantagens. Recorrendo a comandos do próprio inp, é possível gerar malhas. Os arquivos de entrada utilizados nos casos de estudo precisam dos seguintes dados de entrada para serem definidos:

- Dimensões no eixo $\mathrm{x}$ dos pontos onde começam e acabam os diferentes materiais (esquematizados na Figura 4.1).

- Número de divisões pretendidas entre cada nó definido anteriormente, isto é, número de divisão entre os materiais.

- Número de divisões radiais.

No caso de poços de um revestimento, 8 parâmetros são suficientes para definir a malha do modelo.

Tendo o problema dois eixos de simetria nos eixos $\mathrm{x}$ e $\mathrm{y}$, apenas $1 / 4$ do modelo foi analisado.

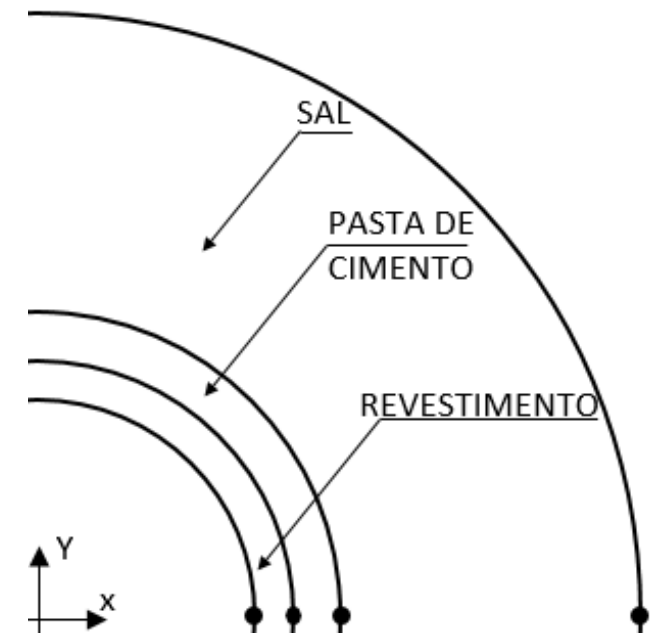

Figura 4.1 - Esquematização dos parâmetros necessários para definir a malha através do inp

Nesta análise, a cada mudança de propriedades da pasta de cimento, um novo arquivo de entrada tem que ser gerado. A menos do primeiro arquivo de entrada, os restantes dependem sempre do seu anterior. Com o grande número de arquivos, a extração de resultados verificou-se demorada.

O capítulo 3.3.2 apresenta duas estratégias que fielmente simulam o incremento das propriedades mecânicas da pasta ao longo do tempo: a primeira estratégia utiliza a ferramenta UMAT; a segunda estratégia utiliza a formulação implementada por default no ABAQUS e corrige o estado de tensão no passo em que o modulo de elasticidade é alterado. Nos seguintes exemplos utilizou-se a 
segunda estratégia. Como tal, é necessário um arquivo de entrada para cada mudança de modulo de elasticidade.

A Figura 4.2 representa a automatização do processo. Foram escritos vários arquivos em PYTHON. De destacar o script central Run_Abaqus.py que roda automaticamente os vários arquivos de entrada e os arquivos de extração de resultados. Este script tem a capacidade de aguardar enquanto análises anteriores são executadas. Isto foi conseguido com a opção subprocess.call. Após o processamento dos vários arquivos de entrada inp, este mesmo script executa outros scripts PYTHON para extrair os resultados dos arquivos odb e armazena-os em arquivos de texto. Posteriormente, os arquivos texto são lidos e plotados pelo programa OCTAVE e salvos em formato $p d f$. De ressalvar que, para extrair tensões nos pontos nodais, interpolaram-se os resultados dos pontos de Gauss para os pontos nodais com auxílio do comando getSubset.

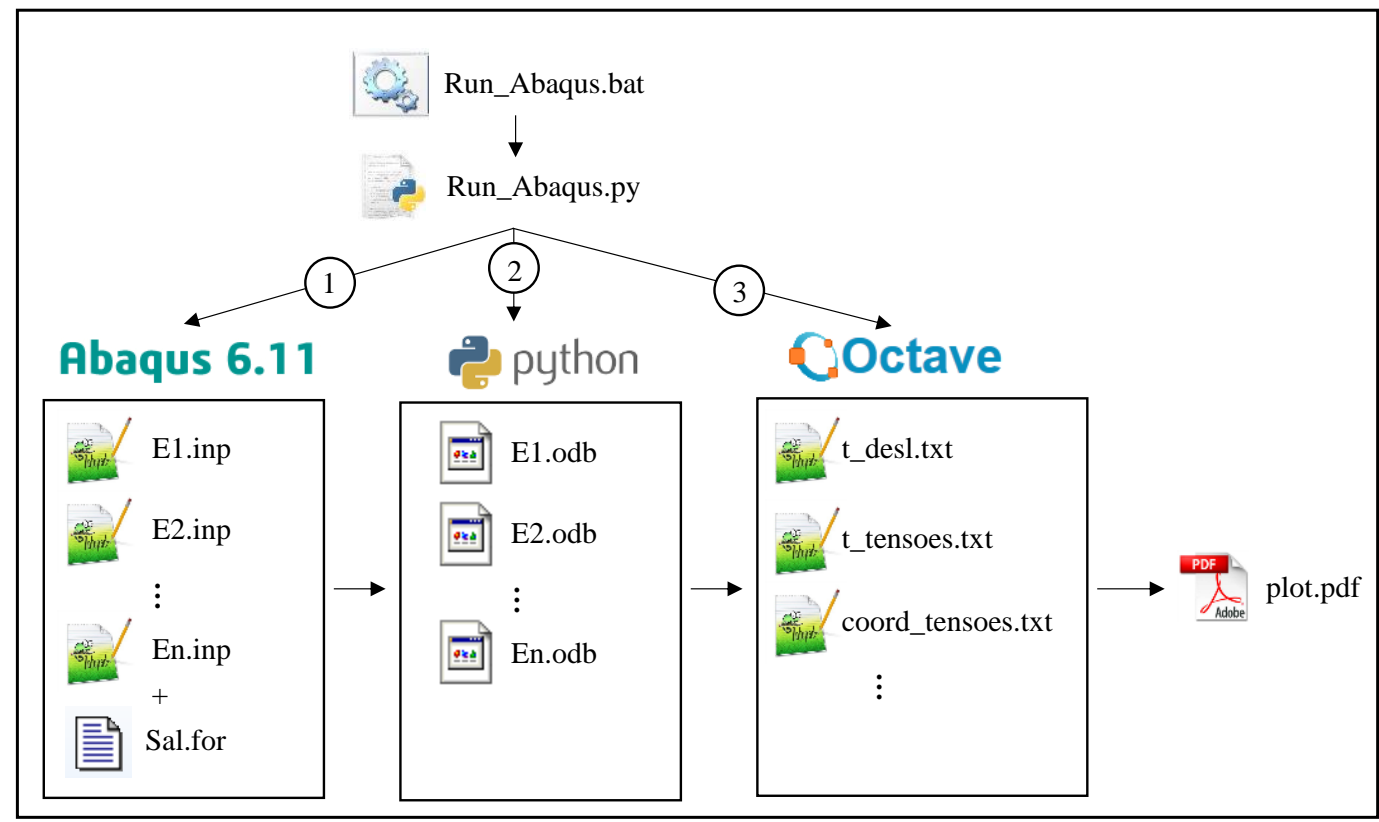

Figura 4.2 - Esquema para a geração de gráficos desde o arquivo de entrada até ao de saída

\section{3.}

\section{Estudo de caso 1}

Este caso de estudo tem o objetivo de comparar os resultados da modelagem e compara-los com a literatura. Além do mais, tem também o objetivo de comparar os resultados do modelo de Lei Híbrida com os modelos constitutivos mais comuns na literatura utilizados com o intuito de simular a fluência do sal. São estes o Duplo Mecanismo e Multi Mecanismo. 


\subsection{1. \\ Dados geométricos e magnitudes}

Os dados geométricos aplicados no presente caso de estudo foram equivalentes aos apresentados por Fossum \& Fredrich (2007). Os autores avaliam o fechamento do sal num poço com tensão inicial de $84 \mathrm{MPa}$ com o coeficiente do empuxo horizontal de 1.0 e com temperatura de $344.1 \mathrm{~K}\left(\approx 71^{\circ} \mathrm{C}\right)$.

Firme (2013) validou a sua implementação do modelo de duplo e Multi Mecanismo para a halita brasileira com o exemplo de Fossum \& Fredrich (2007). O autor conclui que os dados do exemplo da validação correspondem aproximadamente a estratificação presente na Tabela 4.1. Fossum \& Fredrich (2007) consideraram que o fluido de perfuração produz uma pressão de $64 \mathrm{MPa}$, que corresponde aproximadamente a $11,0 \mathrm{lb} / \mathrm{gal}\left(12,925 \mathrm{kN} / \mathrm{m}^{3}\right)$, com a premissa de que o fluido de perfuração está no poço desde a cota zero até à conta estudada.

Tabela 4.1 - Caracterização das camadas acima da profundidade de controle

\begin{tabular}{cccc}
\hline & $\rho$ & Grad. Geotérmico & Prof. \\
Material & {$\left[\mathrm{kN} / \mathrm{m}^{3}\right]$} & {$[\mathrm{m}]$} \\
\hline Lâmina de água & 10,00 & {$\left[{ }^{\circ} \mathrm{C} / \mathrm{km}\right]$} & 0 até -2000 \\
Outros sedimentos & 22,56 & - & -2000 até -4000 \\
Camada de Sal & 21,29 & 30,0 & -4000 até -5000 \\
\hline
\end{tabular}

A Figura 4.3 mostra esquematicamente os dados geométricos utilizados no modelo. Foi considerado um poço com 46,355 centímetros (18 1/4”) de diâmetro com ovalização de $-4,2 \%$ no eixo x e $0,5 \%$ no eixo y. O modelo 2D foi elaborado com 20 metros. O revestimento metálico é de 17,30 centímetros (13 5/8”) de diâmetro externo, espessura de 1,58 centímetros (0,625”). As propriedades mecânicas e modelos constitutivos foram as descritas no capítulo 3 . 


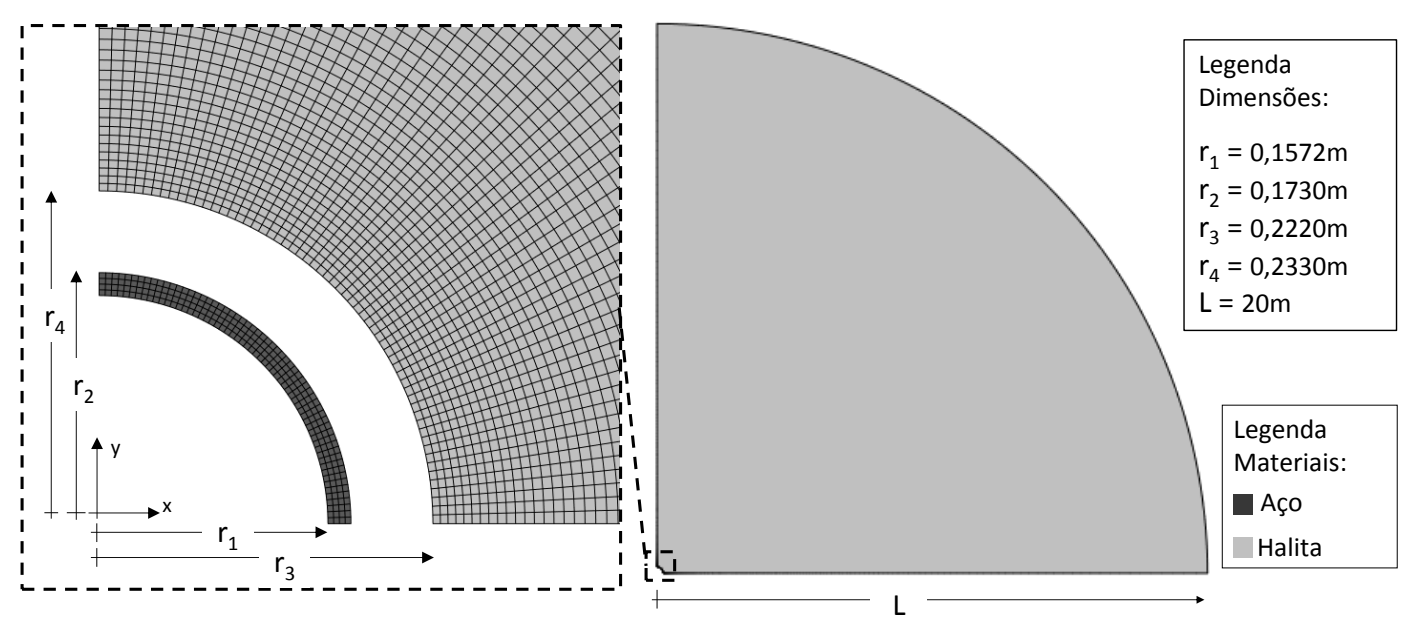

Figura 4.3 - Esquematização do modelo de elementos finitos utilizado para a análise para o estudo de caso 1

O processo tem em conta três diferentes etapas, a aplicação da tensão geostática que simula o estado de tensão da rocha antes de perfurado, a perfuração e a deformação da halita por fluência.

\subsection{2.}

\section{Geostático}

Para a correta simulação do modelo é imperatório considerar as condições iniciais no modelo, isto é, o estado de tensão hidrostático equilibrado a que a rocha está sujeita antes da etapa de perfuração. Nesta etapa, visto que a rocha na profundidade se encontra num estado confinado, as deformações devem ser nulas e as tensões de mesma magnitude nas três direções visto que o coeficiente de empuxo é adotado como unitário.

A modelagem deste passo faz-se já com o revestimento metálico definido tanto mecanicamente como geometricamente no modelo. Utilizou-se a opção * Model Change para desativar o revestimento no início da análise. Foram asseguradas as condições de continuidade do poço nos eixos vertical e horizontal. No plano de simetria vertical o deslocamento horizontal foi restringido e na simetria horizontal o deslocamento vertical foi restringido. Na borda exterior do modelo e os nós correspondentes à parede do poço foram restringidos em ambas as direções. 


\subsection{3. \\ Escavação e reconstrução do revestimento metálico}

Para simular a escavação, existem duas metodologias presentes na literatura. Gray et al. (2007) e Fossum \& Fredrich (2007) simulam removendo os elementos associados à escavação. Macay \& Fontoura (2014) simulam a escavação partindo de um modelo sem os elementos da escavação, mas com a superfície da escavação restringida nas duas direções. Os procedimentos são equivalentes. Nesta simulação a escavação foi simulada com a metodologia apresentada por Macay \& Fontoura (2014). Quando se dá a escavação, é aplicado a pressão equivalente à exercida pelo fluido de perfuração no poço. Visto que a tensão in situ da rocha é superior à aplicada pela lama de perfuração, existe um desconfinamento e uma deformação abrupta até que a pressão exercida pela lama de perfuração equilibre a tensão in situ. Depois, com a tensão equilibrada, o poço sofre um fechamento por fluência.

$\mathrm{Na}$ presente etapa, os elementos correspondentes ao revestimento são considerados e também sujeitos ao efeito do peso de fluido do líquido de perfuração.

\subsection{4. Ação da fluência}

Considerou-se a ação da fluência para um período de 30 anos. Três modelos constitutivos foram considerados neste caso, o Duplo Mecanismo, o Multi Mecanismo e o Modelo Híbrido. De notar que a lei de Multi Mecanismo foge ao escopo deste trabalho, pelo que os resultados apresentados para essa comparação foram cedidos por Firme (2013).

No processo de fechamento, a rocha salina entra em contato com o sal. Nesta análise, o contato entre o sal e o revestimento metálico é simulado através da interação Master-Slave.

\subsubsection{Resultados para Lei de Duplo Mecanismo}

Os resultados de deslocamentos são apresentados em função das coordenadas dos pontos $\mathrm{A}_{1}$ e $\mathrm{A}_{2}$, e $\mathrm{B}_{1}$ e $\mathrm{B}_{2}$. O ponto $\mathrm{A}_{1}$ representa o ponto na parede do poço e $\mathrm{o} \mathrm{A}_{2} \mathrm{o}$ ponto da parede externa do revestimento para $\mathrm{y}=0 . \mathrm{O}$ ponto $\mathrm{B}_{1}$ representa o ponto na parede do poço e o $\mathrm{B}_{2} \mathrm{o}$ ponto da parede externa do revestimento para $\mathrm{x}$ $=0$. Assim, as coordenadas plotadas são as coordenadas xx para os pontos A e yy para os pontos B. 
A Figura 4.4 mostra a diferença das coordenadas dos pontos $A_{1}$ e $A_{2}$, e $B_{1}$ e $\mathrm{B}_{2}$ quando empregue o modelo de fluência de Duplo Mecanismo. Essa diferença é chamada de anular. Assim, a Figura 4.4 mostra que para o tempo inicial o anular B é superior ao anular A, que já seria espectável dado as dimensões do problema (Figura 4.3). Verifica-se que a dimensão dos anulares decresce a uma taxa idêntica até o anular A ter dimensão nula ocorrido aos 22,66 anos de análise. Subsequentemente, neste instante, o ponto $\mathrm{A}_{1}$ tem a mesma coordenada que o ponto $\mathrm{A}_{2}$. Assim, o ponto $\mathrm{A}_{1}$ representa o primeiro ponto da parede do poço que atinge o revestimento metálico (ponto $\mathrm{A}_{2}$ ).

Do tempo 22,66 anos em diante observa-se que a taxa de deformação no tempo do anular B diminui e o anular tem dimensão nula aos 26,91 anos. O período para o qual esta ação decorre é de 4,25 anos. Neste intervalo de tempo, a parede do poço atinge gradualmente o revestimento. A primeira região a fechar é a região entre os pontos A e a última a região entre os pontos B.

Para tempos superiores a 26,91 anos, o anular mantem-se nulo.

Os valores de tempo especificados estão em concordância com aqueles apresentados por Firme (2013). Assim, o objetivo de validar os resultados do modelo tendo como base um exemplo na literatura é atingido.

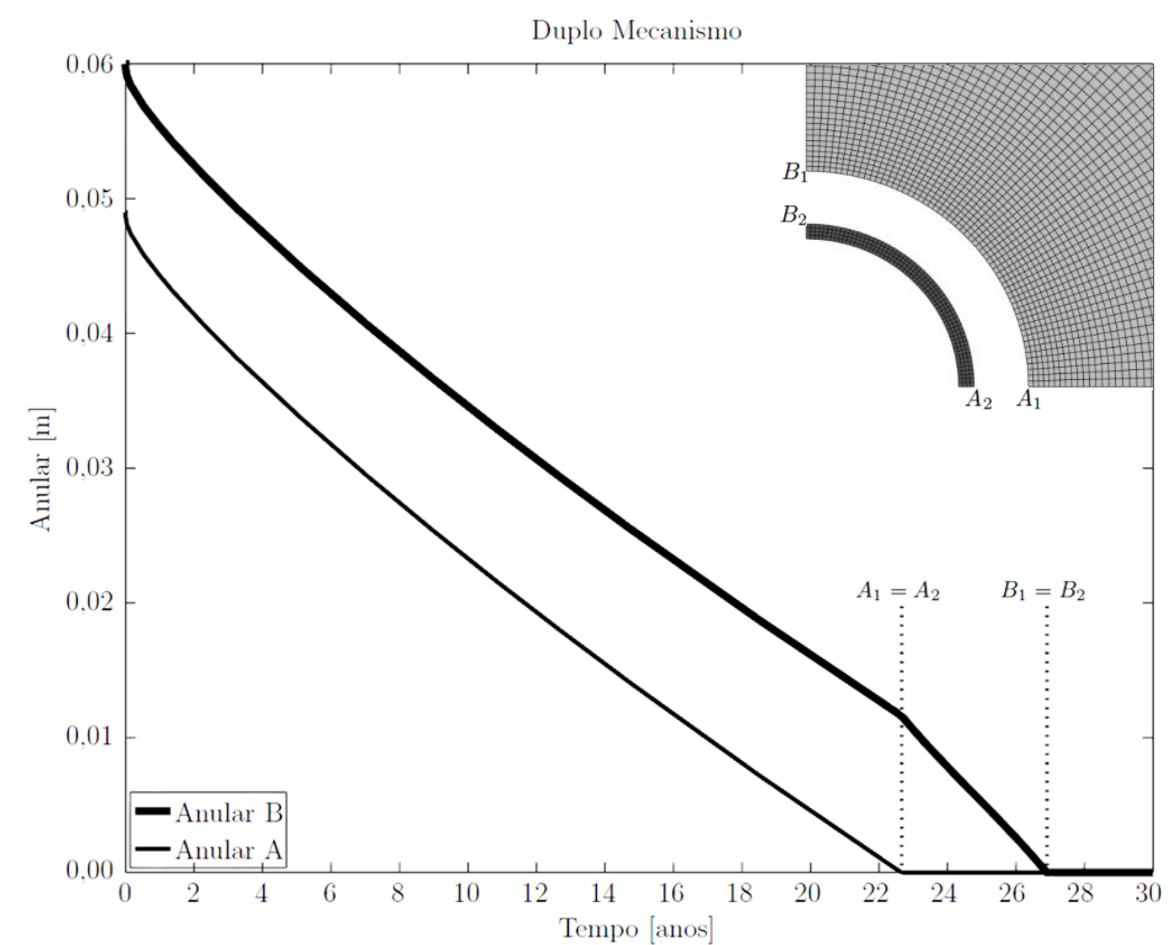

Figura 4.4 - Dimensões dos anulares A e B para o caso de Duplo Mecanismo

A Figura 4.5 tem como objetivo elucidar a ideia apresentada pela Figura 4.4. 
Entenda-se que, com o passar do tempo e consequente ação da fluência, o ponto $\mathrm{A}_{1}$ desloca-se em direção ao revestimento metálico. $\mathrm{O}$ contato acontece quando o valor da coordenada $\mathrm{A}_{1}$ coincide com o valor da coordenada inicial do ponto $\mathrm{A}_{2}$. Após verificar-se esse contato, a taxa de deslocamento diminui devido ao efeito restritivo do revestimento metálico e consequente diminuição da tensão desviadora no sal.

Nesta fase os Pontos $B_{1}$ e $B_{2}$ vão-se aproximando gradualmente até que coincidem. $\mathrm{O}$ anular $\mathrm{B}$ decresce devido à fluência do sal representada pela coordenada $\mathrm{B}_{1}$. Observa-se que o contato dos pontos A produz um aumento de coordenada $\mathrm{B}_{2}$.

Enxerga-se que após o contato estabelecido entre a parede do poço e o revestimento, o deslocamento do sal é praticamente inexistente. Isto é, o efeito de suporte do aço tem uma grande influência no abrandamento do deslocamento por fluência do sal.
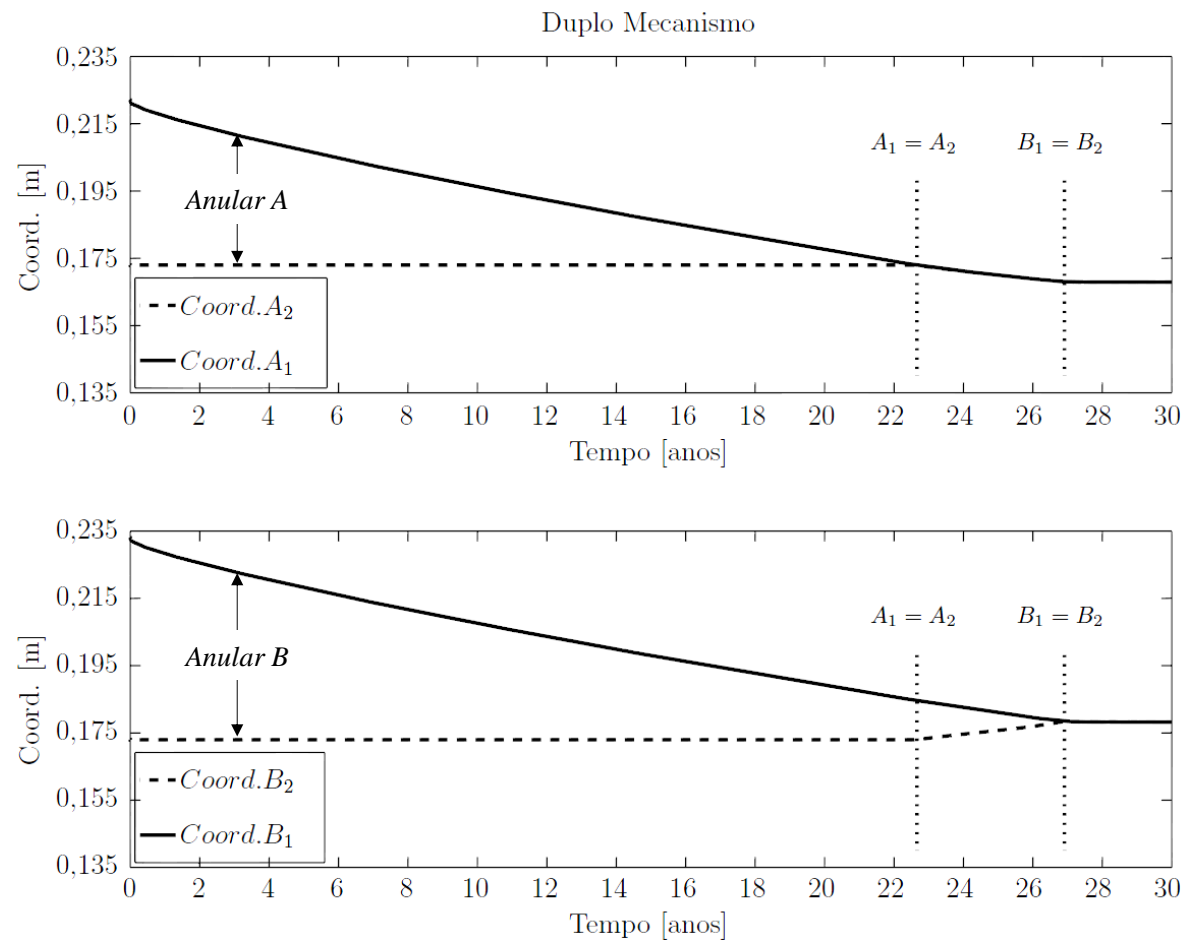

Figura 4.5 - Coordenadas dos pontos $\mathrm{A}_{1}, \mathrm{~A}_{2}, \mathrm{~B}_{1}$ e $\mathrm{B}_{2}$ para o para o caso de Duplo Mecanismo

\subsubsection{Resultados para Lei Híbrida}

A Figura 4.6 e Figura 4.7 mostram que os resultados apresentados para a Lei Híbrida são semelhantes aos observados para a Lei de Duplo Mecanismo (Figura 4.4). O contraste assinalável reside no instante de tempo no qual o anular apresenta 
valor nulo. $\mathrm{O}$ anular A tem distancia zero no instante 22,38 anos e o anular B no instante 26,63 anos.

Ao comparar os resultados para a Lei Híbrida e de Duplo Mecanismo, constata-se que o tempo entre o contato dos pontos A e os pontos B mantem-se constante com valor de 4,25 anos. Porém, os valores de contato entre os pontos de referência para a Lei Híbrida são inferiores em 0,3 anos quando comparados com os da Lei de Duplo Mecanismo.

Contatou-se que a taxa de deformação ao longo do tempo é semelhante tanto para a Lei Híbrida e de Duplo Mecanismo, mas devido à fluência primária considerada pela Lei Híbrida, o fechamento do poço tem um valor mais expressivo no início da modelação que se propaga a toda a modelagem.

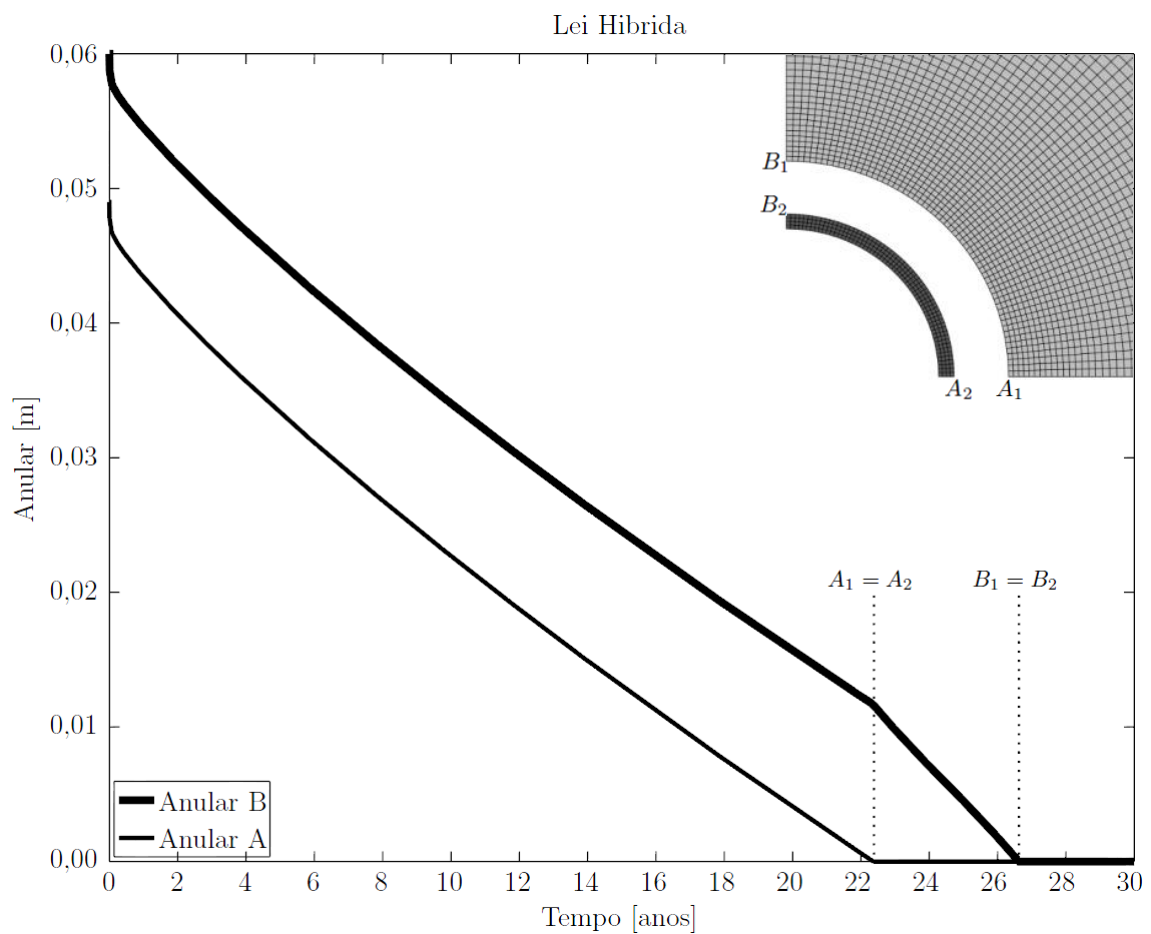

Figura 4.6 - Dimensões dos anulares A1 e A2 e B1 e B2 para o caso da Lei Híbrida 

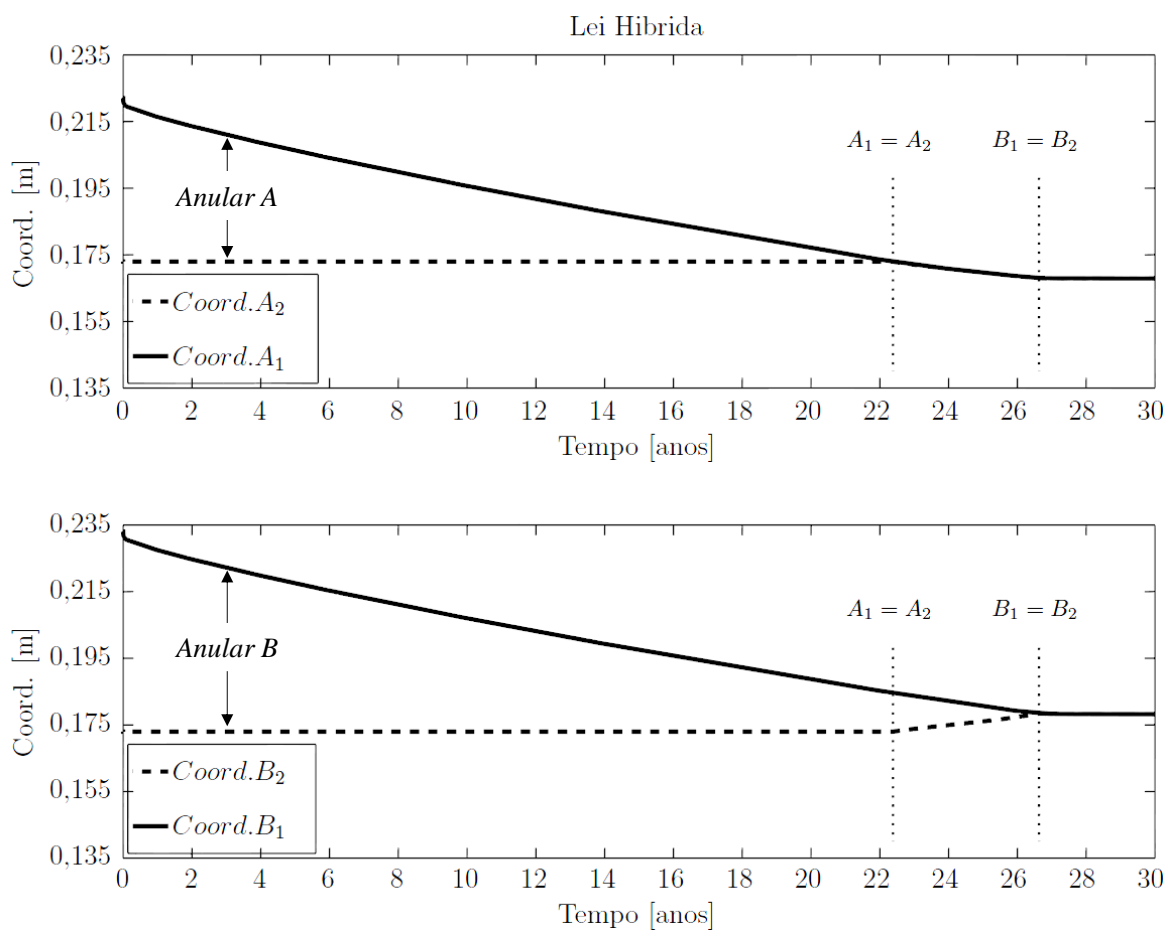

Figura 4.7 - Coordenadas dos pontos $\mathrm{A}_{1}, \mathrm{~A}_{2}, \mathrm{~B}_{1}$ e $\mathrm{B}_{2}$ para o para o caso da Lei Híbrida

\subsubsection{3.}

\section{Comparação das análises}

A Figura 4.8 apresenta a coordenada do ponto $A_{1}$ ao longo do tempo com o intuito de compara as análises empregando diferentes leis de fluência do sal - o Duplo Mecanismo, o Multi Mecanismo (dados cedidos por Pedro A. L. P. Firme do grupo de geomecânica computacional do Tecgraf presentes no trabalho Firme (2013)) e o modelo apresentado neste estudo, a formulação Híbrida. Verificou-se que para a Lei Híbrida e de Duplo Mecanismo os pontos A coincidem em diferentes instantes, mas porém próximos no tempo. O anular A é nulo no instante 22,38 anos para a Lei Híbrida e 22,66 anos para a Lei de Duplo Mecanismo. Para facilitar a representação na Figura 4.8, tomou-se a média desses valores (22,5 anos) para representar o instante em que a dimensão do anular A toma a dimensão zero para essas duas formulações. O tempo para o qual os pontos B apresentam a mesma coordenada não foram plotados.

Como comentado anteriormente, tanto a Lei Híbrida como a Lei de Duplo Mecanismo dão resultados semelhantes a longo prazo. Verifica-se também, que a longo prazo, as Leis de Duplo Mecanismo e Híbrida fornecem resultados mais conservadores que os do Multi Mecanismo. 


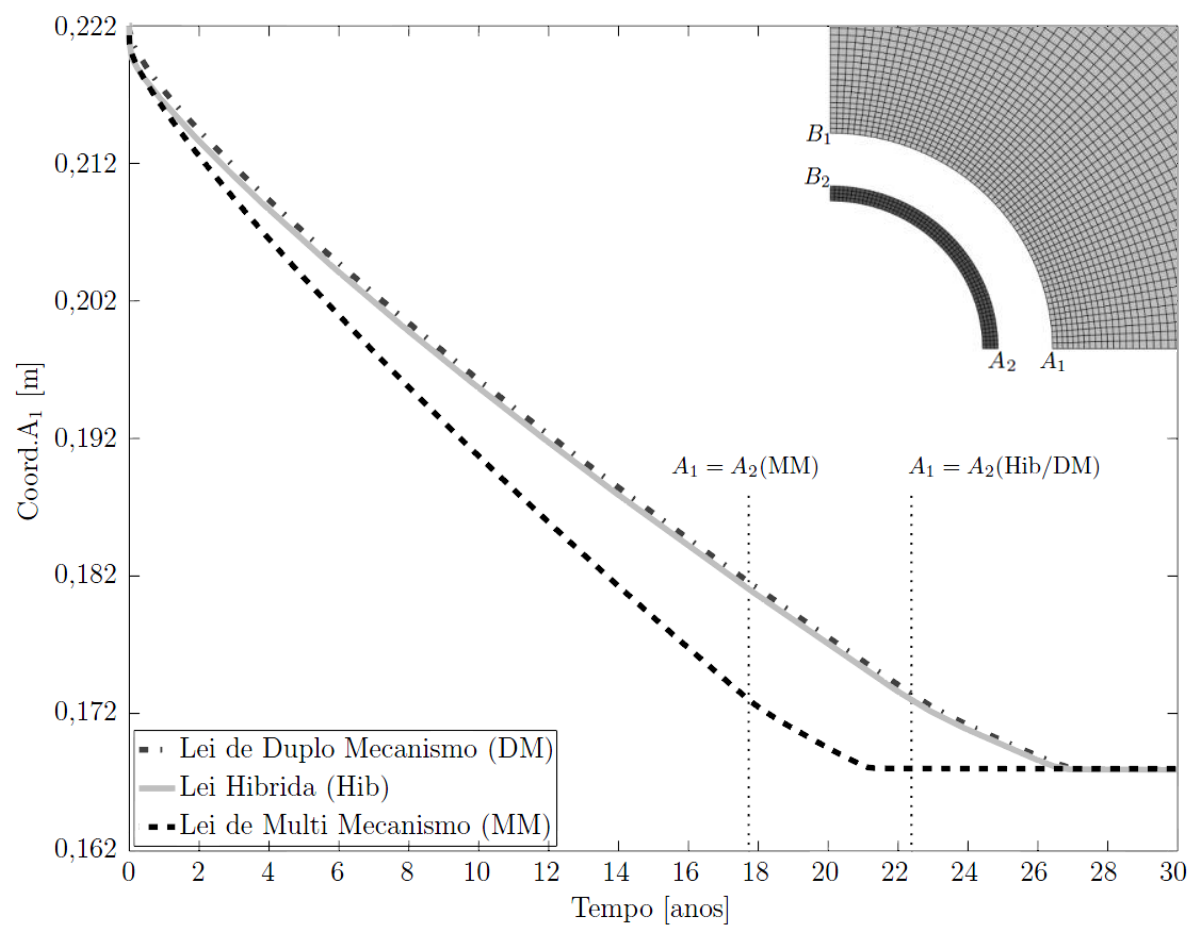

Figura 4.8 - Avaliação a longo prazo do fechamento do ponto A ao longo do tempo

A Figura 4.9 mostra os valores de coordenada A1 para as primeiras 4400 horas ( $\sim 6$ meses) da análise. Observa-se que os valores de deslocamentos dados pela lei Híbrida são superiores às outras duas teorias até, aproximadamente, as 3200 horas (5 meses). Esta teoria deriva da Lei da Potência para curto prazo que define o primeiro estágio da fluência. O período de construção do poço é normalmente feito num período máximo de 720 horas, correspondente a 1 mês. Como visto anteriormente, depois do contato estabelecido entre o sal com outro material, a ação da fluência deixa de ter praticamente efeito.

Desta forma, a teoria Híbrida apresenta então as suas vantagens. Esta é uma teoria menos complexa computacionalmente e com valores próximos quando comparada com a Lei de Multi Mecanismo. Além do mais, a lei apresentada necessita de menos parâmetros. Conclui-se então que na prática, a lei Híbrida traz resultados válidos no contexto de poço. 


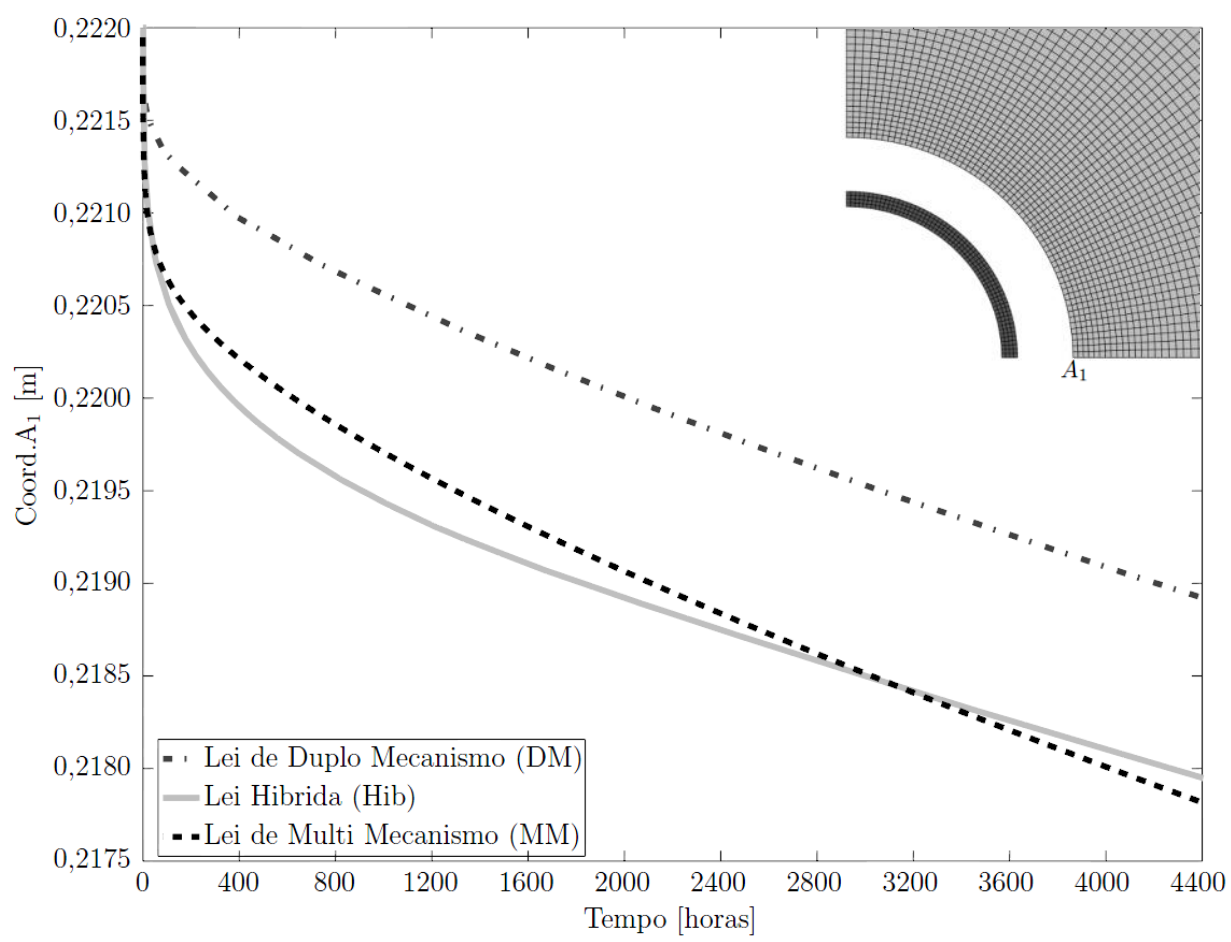

Figura 4.9 - Avaliação a curto prazo do fechamento do ponto A ao longo do tempo

\section{4. \\ Estudo de caso 2}

O segundo estudo de caso teve como base o primeiro, com a consideração da pasta de cimento descrita no capítulo 3. A menos da ovalização do poço, os dados geométricos, temperatura e valores de pressões foram mantidos. Neste caso considera-se que a pasta de cimento produz uma pressão de 92,825 $\mathrm{MPa}$, que equivale a um peso de fluido $15,8 \mathrm{lb} / \mathrm{gal}(18,565 \mathrm{kN} / \mathrm{m} 3)$ e com a simplificação que a coluna de cimento tem extensão de 5 quilômetros (profundidade da cota em estudo). A simplificação considera que o anular está preenchido com pasta de cimento desde a linha de água até a cota em estudo.

Neste, as etapas explicadas nos consequentes capítulos, foram feitas com base em De Simone et al. (2015). Neste processo observam-se as modificações das deformações nos três materiais, pasta de cimento, aço e sal. As propriedades mecânicas e modelos constitutivos foram as descritas no capítulo 3. É apresentado através da Figura 4.10 as dimensões geométricas do segundo caso de estudo. O modelo Híbrido foi o adoptado como lei de fluência do sal. Admite-se que a retração autógena e a perda de água se dão quando o cimento não tem rigidez para resistir à diminuição de volume da pasta, isto é, na fase líquida. A retração autógena 
originada pela contração dos poros e a perda de água foram desconsideradas do modelo para o cimento no estado sólido.
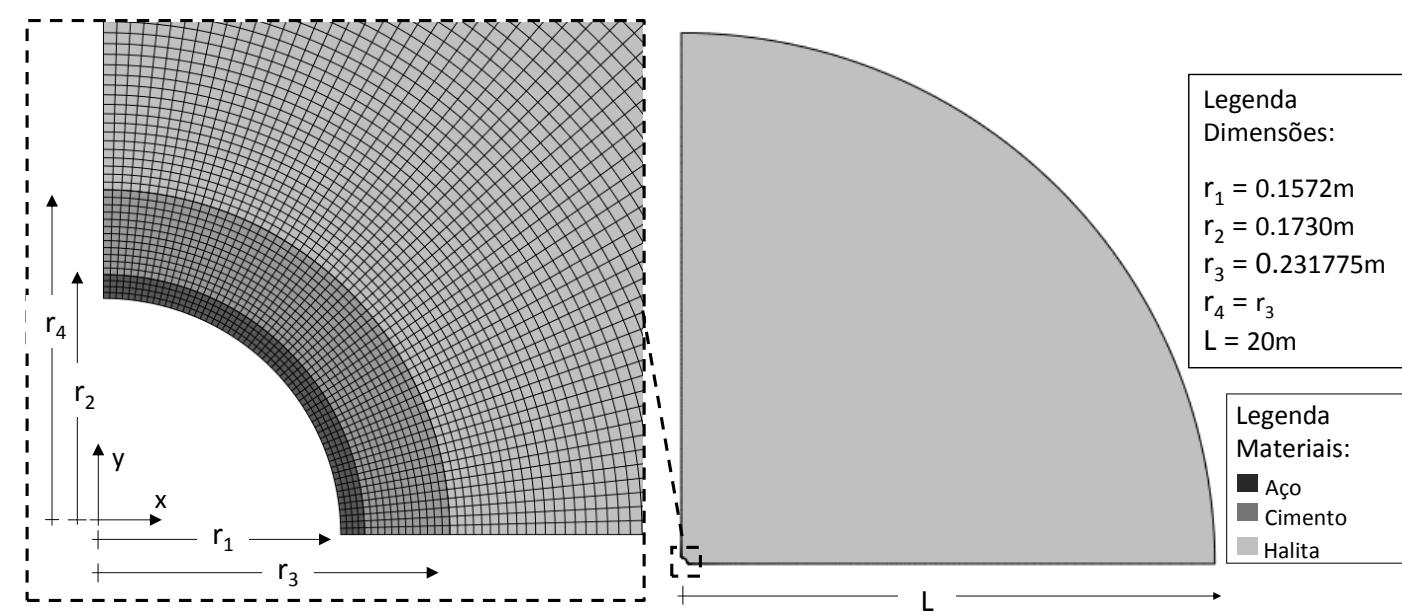

Figura 4.10 - Esquematização do modelo de elementos finitos utilizado para a análise para o estudo de caso 2

\subsection{1.}

\section{Geostático}

A etapa e a verificação de tensões geostáticas do modelo foram já anteriormente descritas na seção 4.3.2. No presente caso de estudo, além do aço, a pasta de cimento foi também definida e desativada com recurso à opção *Model Change.

\subsection{2.}

\section{Escavação e ação da fluência do sal}

Adoptou-se o mesmo processo de perfuração do estudo de caso anterior. A reconstrução do poço foi feita num período de 720 horas, ou seja, 1 mês. Neste período, observa-se que a ação do sal diminui o espaço anular entre o revestimento e o sal. A Figura 4.11 mostra o diâmetro anular ao longo do tempo. 


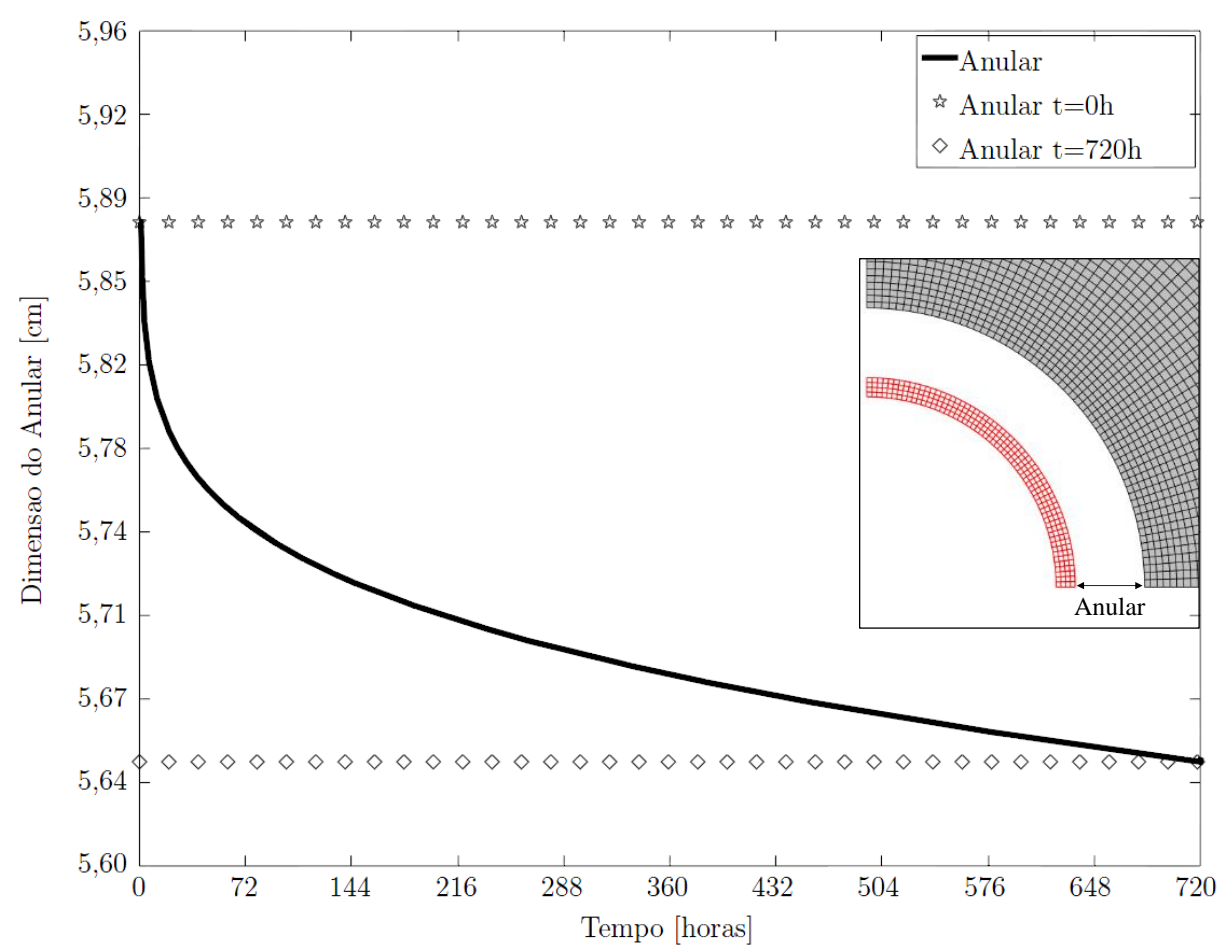

Figura 4.11 - Fechamento do anular depois da perfuração

Como apresentado anteriormente, a fluência do sal depende da temperatura, tensão desviatória e tempo. Assumindo-se a temperatura constante, a tensão desviatória é a única variável no tempo.

$\mathrm{Na}$ perfuração, e ao aplicar a carga no poço, gera-se inicialmente um deslocamento elástico que equilibra as tensões geostáticas. Esse equilíbrio elástico é alcançado logo no primeiro incremento de tempo. No processo geram-se tensões desviatórias que são contabilizadas pelo critério visco do sal. À medida que existem incrementos de deformação, existe um relaxamento de tensões.

A Figura 4.12 mostra a evolução da tensão de von Mises, ou tensão desviadora representada pela letra $q$, em função do tempo. Inicialmente ( $\mathrm{t}=0$ horas) o sal ainda não foi perfurado e a tensão é nula. Uma vez que a se considera a condição inicial hidrostática para o mesmo, este valor seria espectável. Depois do desconfinamento da parede do poço pela perfuração, um incremento de tensão é enxergado. 


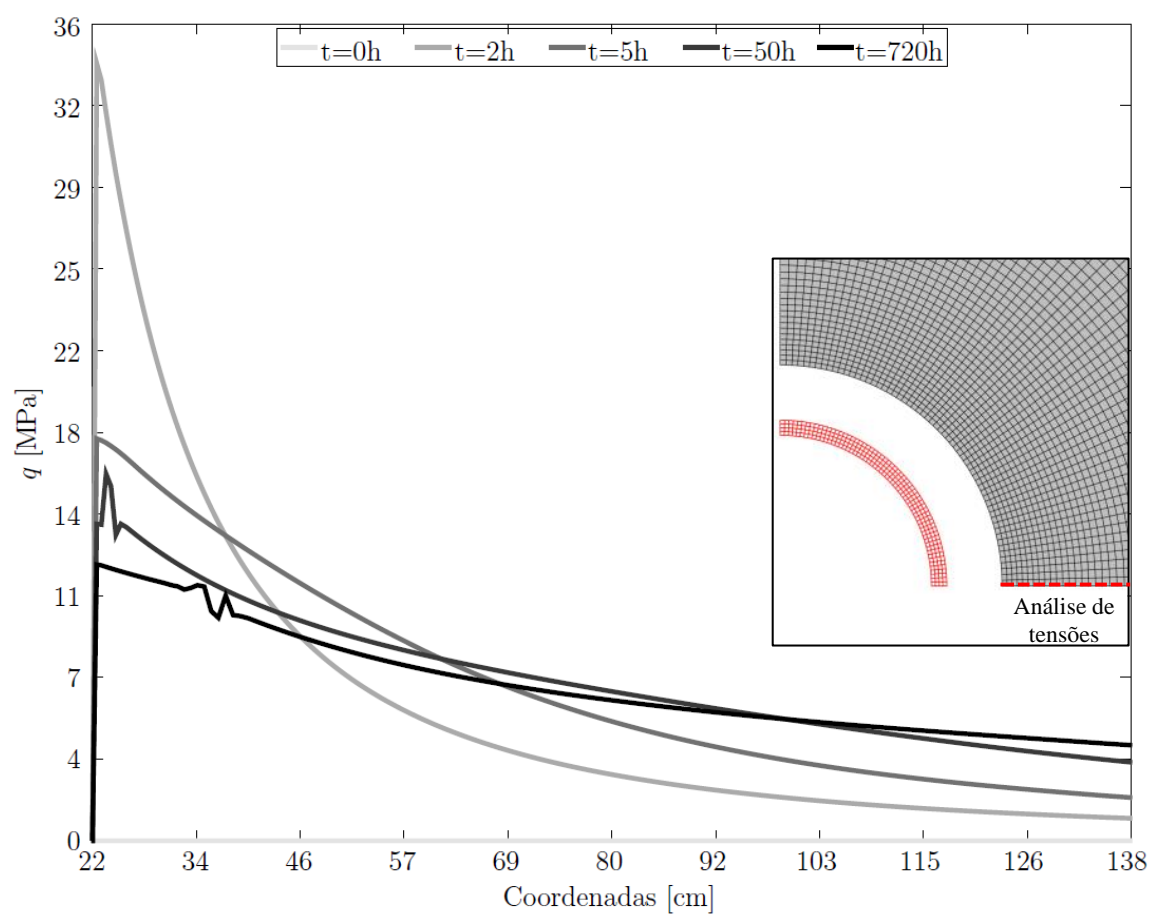

Figura 4.12 - Análise das tensões de von Mises na direção radial no sal após a perfuração do poço

\subsection{3.}

Reconstrução do aço e bombeamento da pasta de cimento

Após a perfuração e a ação da fluência, o poço é reconstruído. Como anteriormente discutido na seção 3.3, nesta fase, a pasta de cimento em estado líquido será simulada por uma pressão exercida na parede do poço e no revestimento metálico. No início deste período, às 720 horas, o revestimento metálico é colocado.

O processo de bombeamento e os tempos para cada fase são explicados anteriormente na seção 2.2. A pasta é bombeada através do interior do revestimento que depois ascende pelo anular. A modelagem da etapa procura simular este processo. Os intervalos de tempo de cada fase são susceptíveis à cota estudada. Além do mais, a pressão do anular é função do peso de toda a coluna de líquido do nível de água até à cota estudada, coisa que foi desconsiderada neste modelo. No presente modelo adotou-se a pressão no anular calculada através da multiplicação da profundidade pelo peso volumétrico.

O presente problema é modelado em estado plano de deformação. Para simular o processo de bombeamento da pasta, consideraram-se 4 fases. Na primeira fase a lama de perfuração está dentro do revestimento e anular. Depois, no segundo passo, a pasta de cimento encontra-se dentro do revestimento e o líquido de 
perfuração no anular. Na terceira fase, a pasta de cimento encontra-se no anular e dentro do revestimento. Na quarta fase, a pasta de cimento está dentro do anular e o fluido de perfuração dentro do anular. Neste passo, existe uma diminuição de pressão hidrostática no anular que simula a retração autógena da pasta líquida e perda de água. Cada fase é apresentada esquematicamente na Figura 4.13.

O estudo simplificou os tempos para cada fase e considerou que na cota estudada, os passos 1, 2 e 3 demoram 1 hora. As cargas aumentaram linearmente neste período de tempo. Esta simplificação é válida uma vez que o problema se desenrola no regime elástico e as cargas de pressão chegam sempre ao valor máximo. O que altera é o tempo que demoram a atingir esse mesmo máximo. Portanto, o deslocamento é igual no final da análise para qualquer tempo tomado para o tempo 1, 2, 3 e 4. Só a fluência é que influência neste tempo. Porém, o tempo é demasiado curto para este efeito ser relevante.

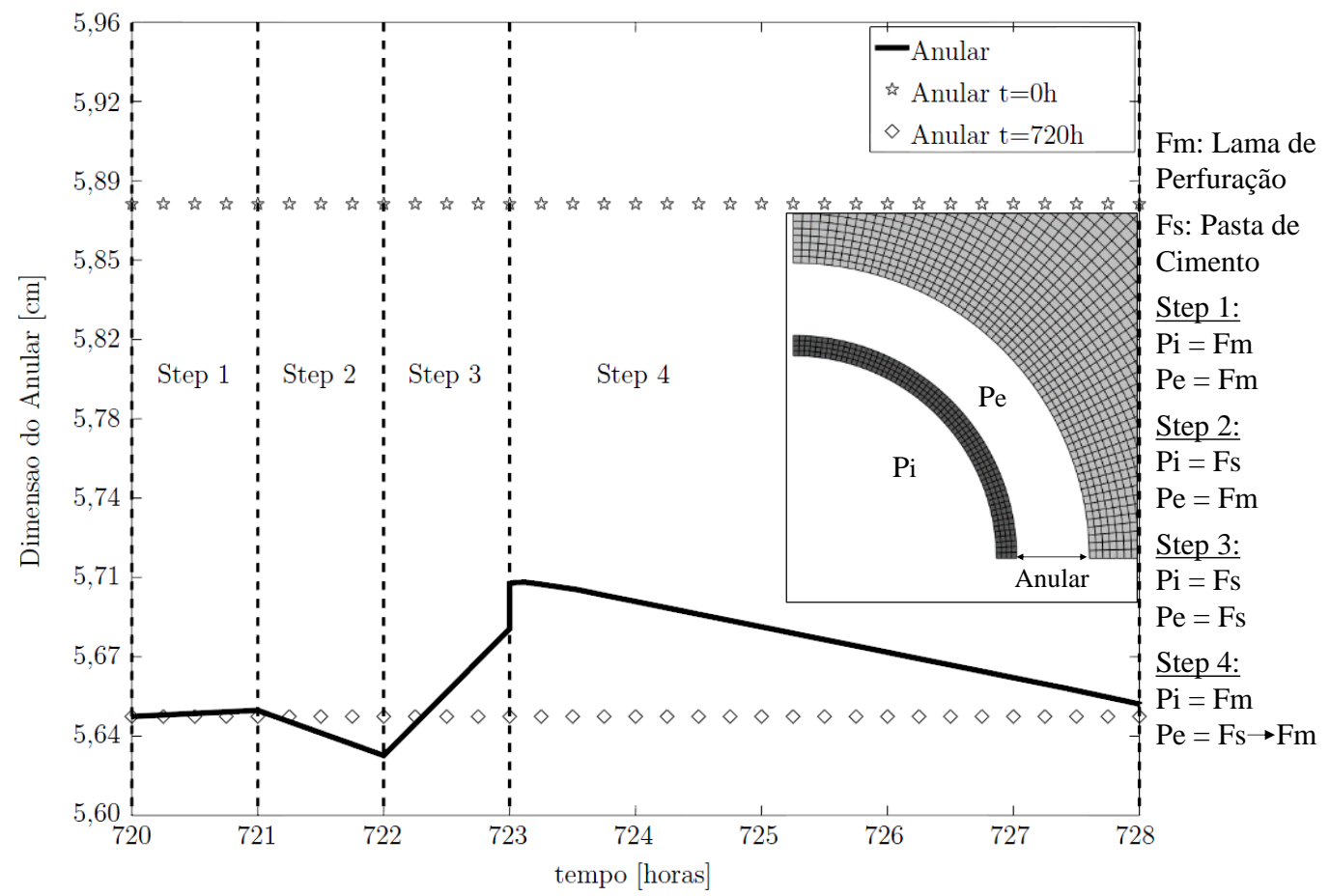

Figura 4.13 - Espaço anular no processo de reconstrução do aço e bombeamento do cimento com esquematização das pressões no interior do revestimento $(\mathrm{Pi})$ e exterior $(\mathrm{Pe})$

Como apresentado esquematicamente na Figura 4.13, a reconstrução do aço (Fase 1) é feita com a pressão do fluido de construção no interior do poço (Pi) e anular (Pe). Observa-se um ligeiro aumento espectável no anular, justificado pelo maior perímetro da face exterior em relação à interior. Logo, a força resultante é superior no sentido negativo o que provoca um deslocamento negativo. 
A $2^{\text {a }}$ Fase da Figura 4.13 representa o bombeamento da pasta de cimento através do interior do revestimento. A pressão da pasta de 15,8 lb/gal é exercida no interior do revestimento $(\mathrm{Pi})$ é a pressão do fluido de perfuração no exterior do revestimento $(\mathrm{Pe})$. Nesta fase há uma diminuição do anular justificada pelo desbalanço das forças entre o interior e exterior do revestimento, empurrando o revestimento metálico em direção à parede do poço.

$\mathrm{Na} 3^{\mathrm{a}}$ Fase da Figura 4.13, a modelagem considera a pasta cimentícia no anular $(\mathrm{Pe})$ e no interior do revestimento (Pi). Por motivos explicados na $1^{\mathrm{a}}$ Fase, a dimensão do anular aumenta.

$\mathrm{Na}$ Fase 4, a pressão no interior do revestimento (Pi) nesta fase é a do fluido de perfuração e no espaço anular (Pe) a pressão correspondente a pasta de cimento. Esta pressão (Pe) sofre um decaimento. Neste período de 5 horas, a pressão exercida pela pasta tem um valor inicial igual à pressão hidrostática da pasta de cimento (15,8 lb/gal) e decai até ao valor do fluido de perfuração $(11 \mathrm{lb} / \mathrm{gal})$.

Constata-se que a dimensão do anular é sempre superior a $1,9 \mathrm{~cm}$, exigência requerida pela norma que a API aconselha a utilizar um raio anular superior a 1,9 cm (0,75”). Observa-se também que para este caso específico, a dimensão do anular ficou praticamente constante desde a perfuração até à caída da pressão hidrostática e o estado de tensão final é praticamente idêntico ao inicial neste passo. Uma vez que os materiais se encontram no regime elástico, esta constatação era espectável. O gráfico mostra uma ligeira discrepância entre a dimensão inicial e final do anular por conta do efeito da fluência do sal.

\subsection{4.}

\section{Pega da pasta cimentícia}

Nesta seção será apresentada a metodologia empregue para ajustar a malha da pasta de cimento ao espaço anular e os resultados de deformação e tensão devido a hidratação do material com os dados experimentais de Pfeifle et al. (2001) e Rocha (2015)

\subsubsection{1.}

\section{Ajuste da malha da pasta de cimento ao anular}

A documentação do ABAQUS alerta que incompatibilidades da malha podem ocorrer em problemas geotécnicos com fluência e reativação de elementos, visto 
que a reativação desses constituintes é feita com a configuração geométrica inicial. Macay \& Fontoura (2014) referem que a opção *TIED aliada à subopção adjust resolveria esse problema. Contudo, o contato é fixado no início da análise e mantem-se inalterado até ao final. Portanto, a opção adjust iria apenas ajustar geometricamente as duas malhas no início da análise e não na reativação dos elementos.

Para suprimir incompatibilidades, foi adicionado um novo conjunto de elementos que partilham o mesmo conjunto de nós que os elementos da pasta cimentícia. Este, é um conjunto de elementos de auxílio à modelagem do poço, definidos como um material de rigidez praticamente nula, com o objetivo de deformar geometricamente a malha da pasta de cimento enquanto esta estiver desativada. O nome dado a este novo conjunto auxiliar foi de cement decoy. A malha cement decoy é ativada no início da escavação e desativada na reativação dos elementos da pasta de cimento. A alta flexibilidade permite a livre deformação do material e assegura a permanência do estado de tensão do aço e do sal. Uma vez que os elementos da pasta de cimento e cement decoy partilham os mesmos nós e sendo os elementos geometricamente definidos pelas coordenadas nodais, ao deformar a malha do cement decoy, a malha da pasta de cimento desativada também é igualmente deformada geometricamente. Na reativação, os elementos definidos com as propriedades da pasta de cimento adaptam-se perfeitamente ao anular. A Figura 4.14 expressa as vantagens da utilização dessa metodologia. A Figura 4.14a) utiliza a metodologia apresentada, ao passo que as outras duas análises não utilizam. A Figura 4.14b) mostra que no final da reconstrução, os elementos da malha de cimento em contato com a rocha salina são deformados na reativação do elemento ao passo que mais nenhum outro elemento da malha é deformado. No caso da Figura 4.14c), modelou-se o poço com uma pressão inicial na halita de $100 \mathrm{MPa}$. Nesta situação, a escavação tem deformações mais críticas e na reativação da pasta de cimento, a deformação é superior à dimensão do elemento da pasta de cimento em contato com a rocha. Neste caso, há uma sobreposição aos elementos da pasta. 


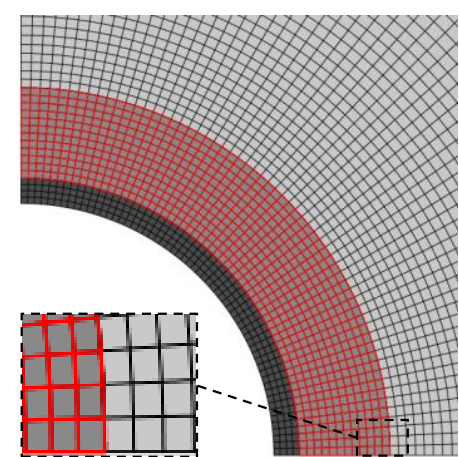

a)

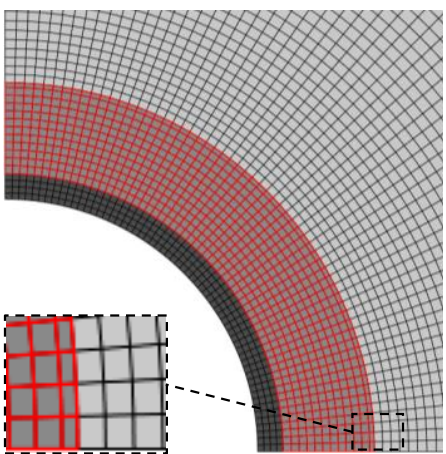

b)

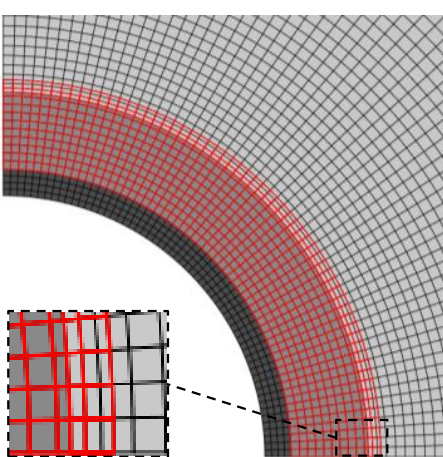

c)

Figura 4.14 - Reativação dos elementos de cimento a) recorrendo à metodologia cement decoy b) sem recurso à metodologia cement decoy c) sem recurso à metodologia cement decoy com aumento do estado de tensão inicial da rocha salina

\subsubsection{2. \\ Resultados - Pasta de cimento elástica com propriedades evolutivas no tempo}

Os resultados são apresentados em forma de deslocamento do anular, tensão radial e tangencial. A análise considera o módulo de elasticidade evolutivo no tempo em consenso com os resultados experimentais de Pfeifle et al. (2001) apresentados na Tabela 2.2 - caso E(t). Este caso será representado pela cor preta nos próximos gráficos. Como termo comparativo, também se apresentam análises idênticas com módulos de elasticidade permanentes nos 28 dias de cura. Foram considerados o menor módulo de elasticidade $-\mathrm{E}(0,6$ dias $)=1,504 \mathrm{GPa}-$ que é representado pela cor vermelha, e o maior módulo de elasticidade $-\mathrm{E}(11$ dias $)=$ 13,5GPa - representado pela cor azul, dos valores da Tabela 2.2. As presentes modelagens consideram a pasta de cimento como material elástico. A Figura 4.15a) compara o fechamento do anular para as três análises com as dimensões iniciais e depois da perfuração do anular. A Figura 4.15b) apresenta o gráfico a uma maior escala com o intuito de entender mais pormenorizadamente o fenômeno de hidratação e a consequente solidificação do material. As linhas a tracejado representam o tempo em que o módulo de elasticidade é alterado com o intuito de simular a escavação. 


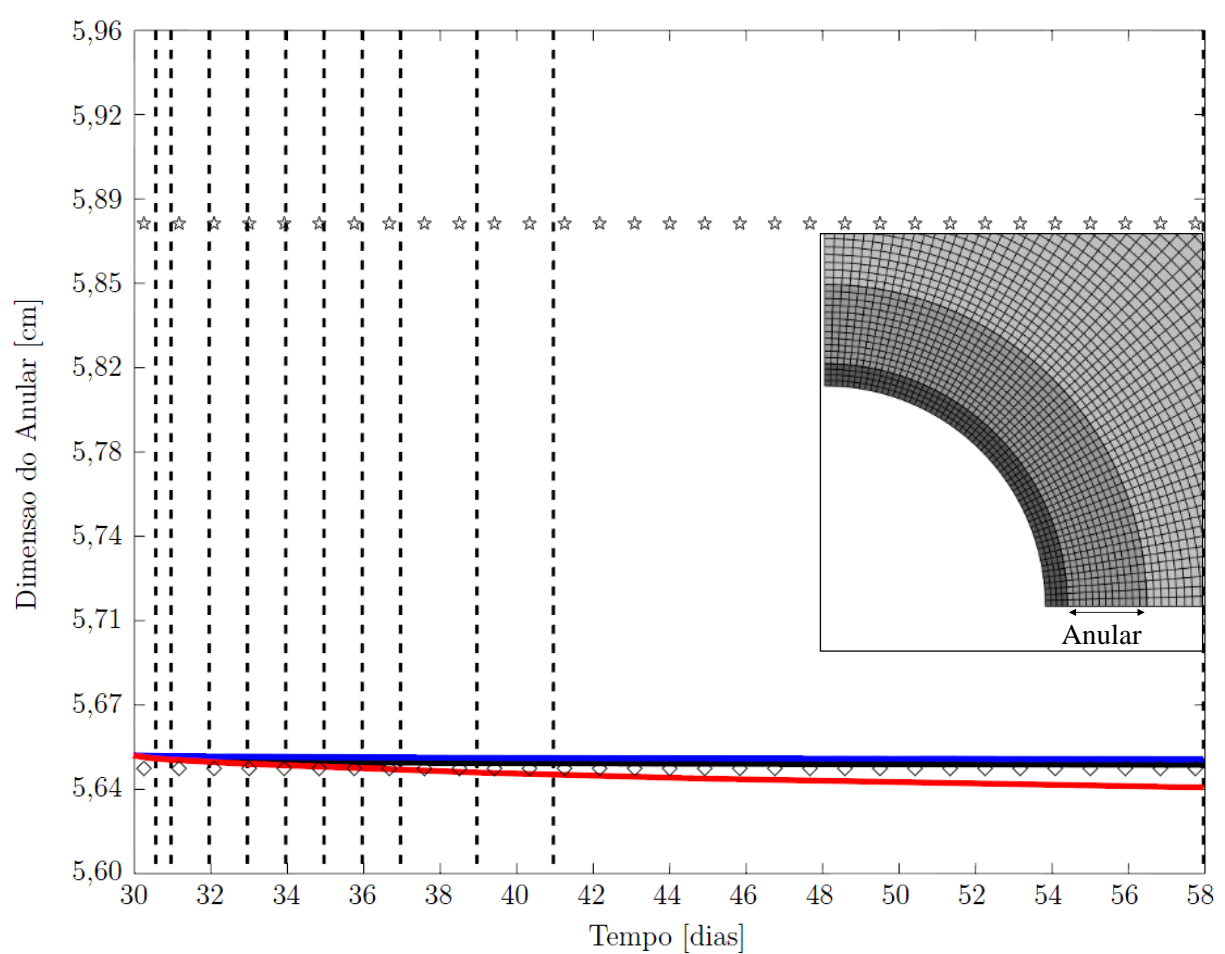

a)

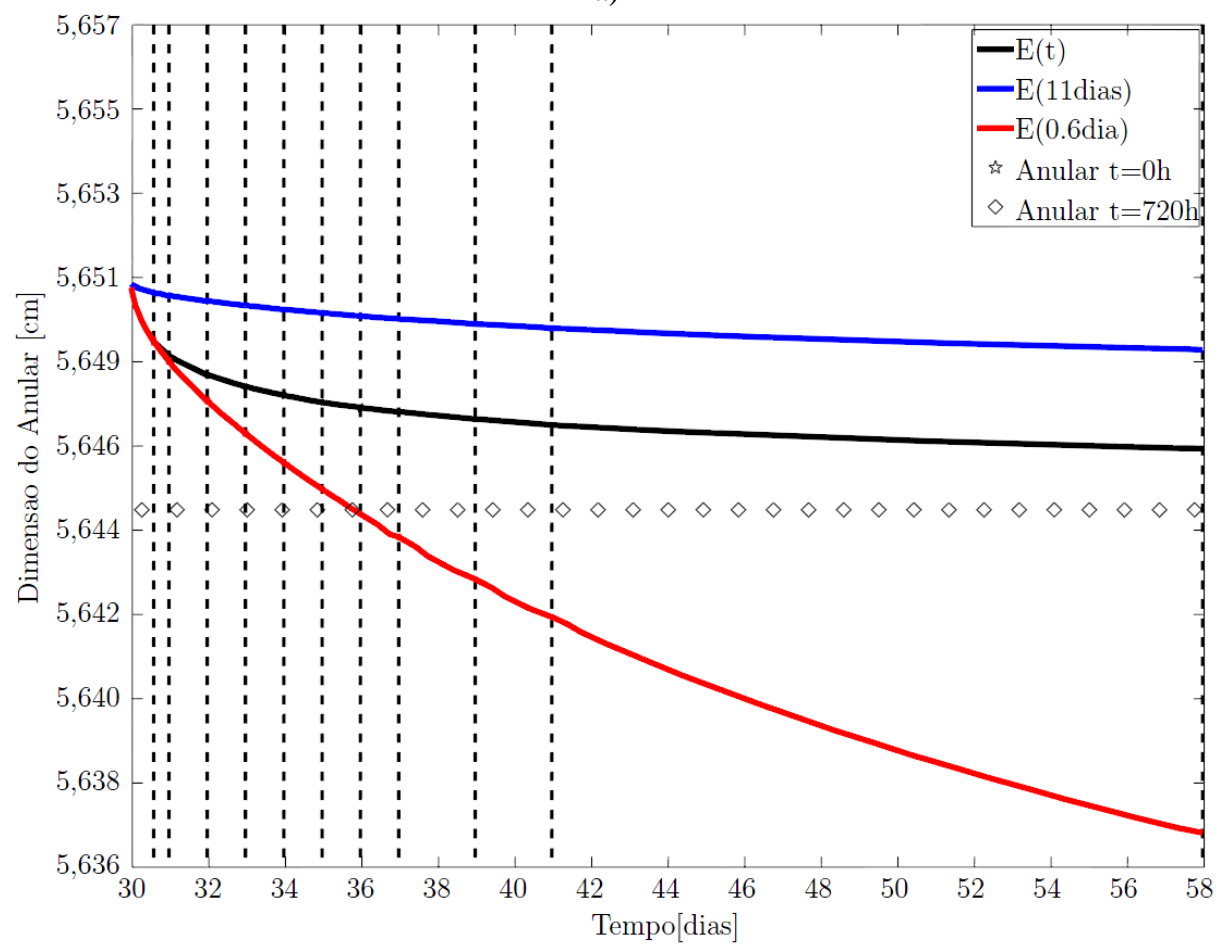

b)

Figura 4.15 - a) Dimensão do anular para o cimento com a evolução das propriedades mecânicas e módulo de elasticidade mínimo e máximo b) zoom in

Duas conclusões podem ser constatadas através da análise do fechamento do anular. Primeiramente, observa-se que ao longo do tempo a taxa de diminuição do espaço anular entre o revestimento é concordante com o incremento de rigidez do material. Os resultados são espectáveis e coerentes com a física do problema. Em segundo lugar, a inclusão do processo de solidificação da pasta de cimento conduz 
a deslocamentos de baixa ordem de grandeza quando comparados com as dimensões do problema. Portanto, a inclusão deste processo na modelagem não traz ganhos significativos aos resultados.

A Figura 4.16 apresenta a distribuição de tensões radiais e tangenciais no revestimento, sal e pasta de cimento para as 3 análises para o $30,6^{\circ}$ e $58^{\circ}$ dia.



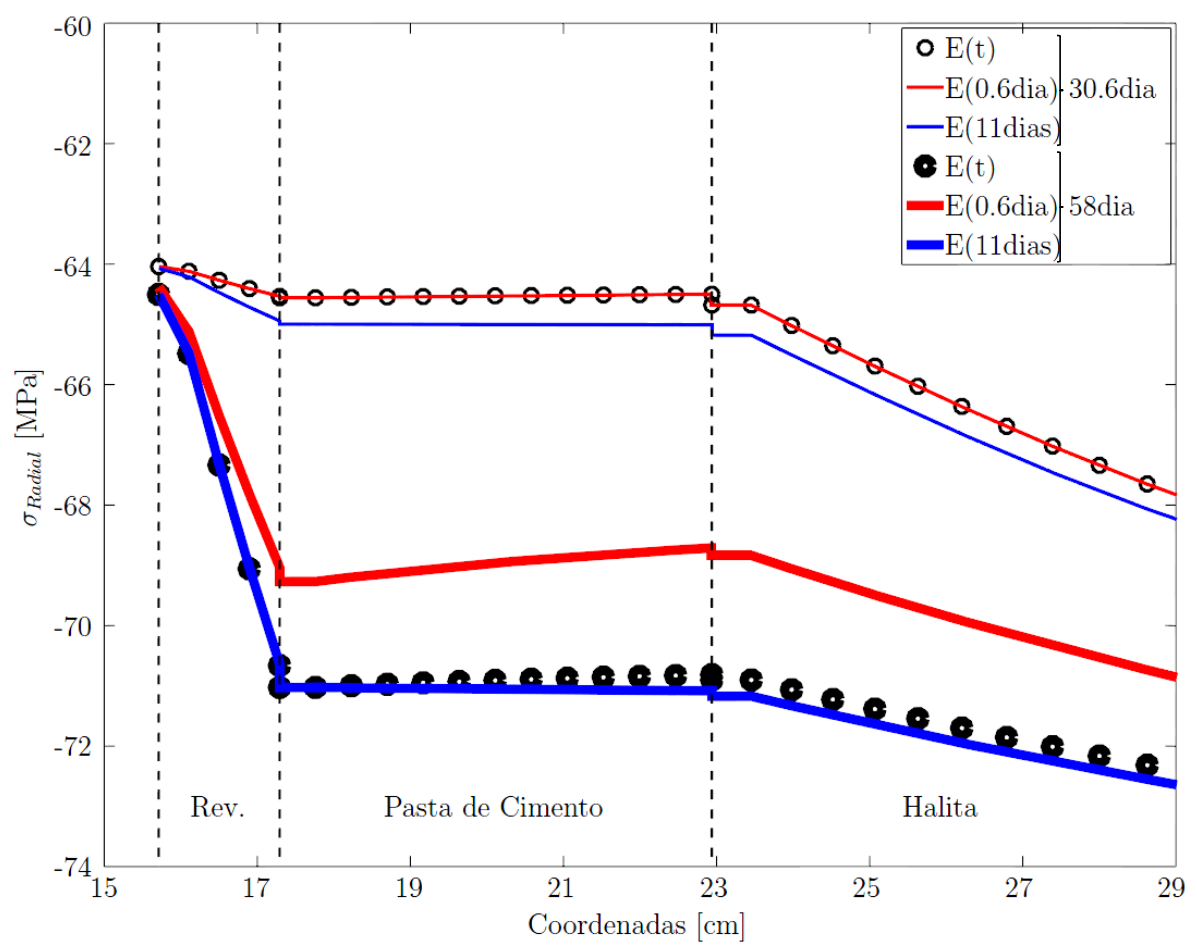

a)

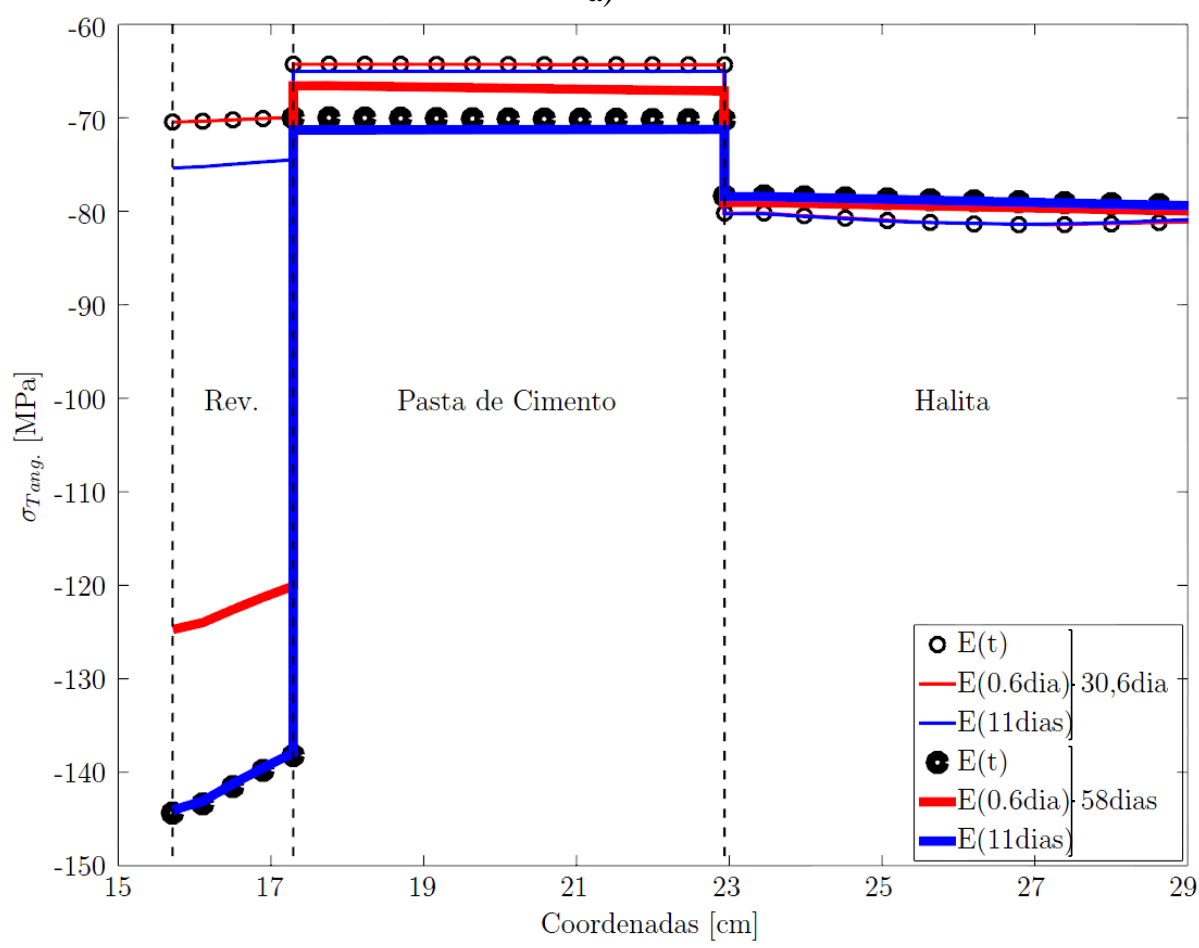

b)

Figura 4.16 - a) Tensão tangencial no revestimento, pasta de cimento e sal b) tensão radial no revestimento, cimento e sal para E constante de 13,5 GPa 
No final da análise do cimento com o primeiro módulo de elasticidade (no tempo 30,6 dias), constata-se a perfeita concordância entre os casos $E(t)$ e $E(0.6$ dias) para as tensões tangenciais e radiais. Esta resposta é espectável pois nesse período ambas as análises consideram o mesmo módulo de elasticidade. Já para o $58^{\circ}$ dia, o estado de tensão na pasta de cimento para o caso $\mathrm{E}(\mathrm{t})$ tem valores ligeiramente inferiores ao da análise E(11dias). Entenda-se que a maior flexibilidade no tempo da análise faz com que a pasta de cimento não restrinja com tanta veemência o deslocamento.

\subsubsection{3.}

\section{Resultados - Pasta de cimento elástoplastica com propriedades evolutivas no tempo considerando efeito de temperatura na cura}

O comportamento da pasta de cimento nesta etapa foi modelado elastoplasticamente com a evolução das propriedades no tempo de acordo com a Tabela 2.3. O modelo empregue na análise foi o de Drucker Prager, D-P1, com a evolução das propriedades mecânicas plásticas de acordo com a Tabela 2.3.

A Figura 4.17 mostra o comparativo das análises já descritas no capítulo anterior com a análise que considera a temperatura $60^{\circ} \mathrm{C}$ nas reações de hidratação.

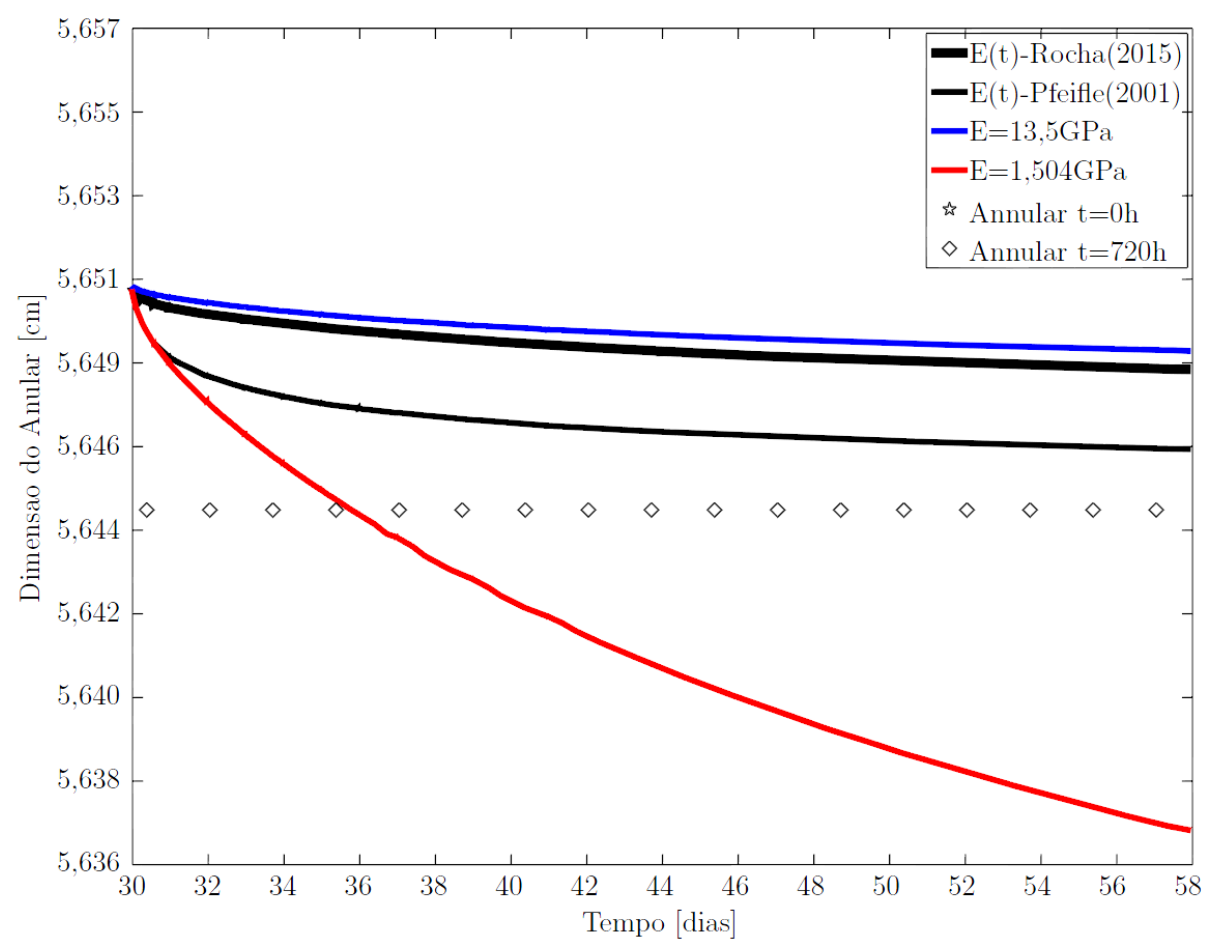

Figura 4.17 - Comparativo do deslocamento do anular para a análise que considera a temperatura de $60^{\circ} \mathrm{C}$ durante as reações de hidratação 
As reações de hidratação são dependentes da temperatura in situ e, caso se considere esse efeito, a inclusão da fase da solidificação da pasta no tempo tornase ainda mais despropositada. Embora os limites de 1,5GPa e 13,5GPa sejam diferentes dos apresentados por Rocha (2015), mostra-se que a análise que considera a evolução das propriedades mecânicas apresentados por Rocha (2015) apresenta valores de dimensão do anular próximos aos da análise que considera o módulo de elasticidade de 13,5GPa. Assim, em concordância com o que já apresentado, a inclusão da solidificação não é relevante.

A Figura 4.18 mostra o estado de tensão (assinalado pelo símbolo "o") da pasta de cimento e as envoltórias de ruptura de D-P1 (Drucker Praguer com o meridiano coincidente com o meridiano de compressão de Mohr Coulomb) para diferentes dias de cura.

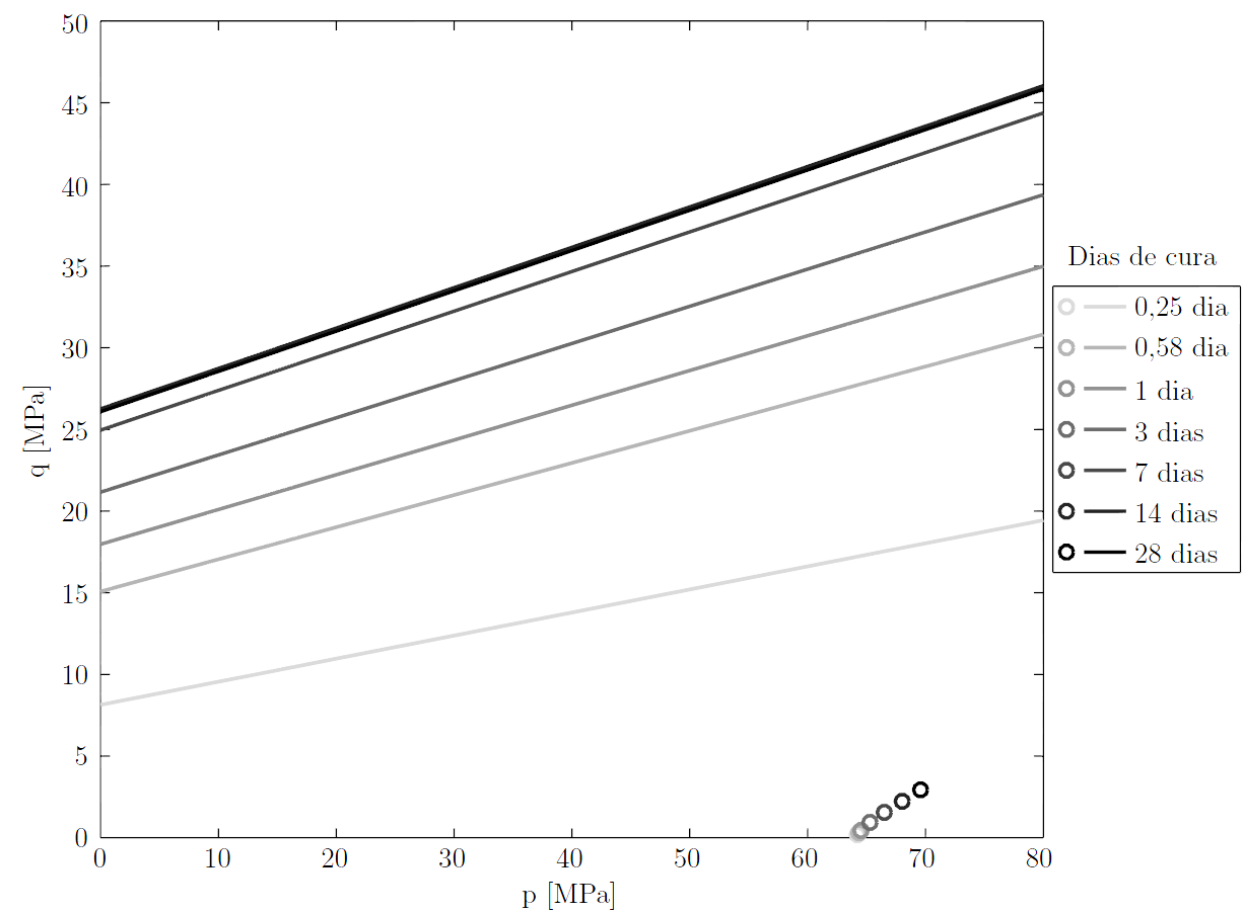

a) 


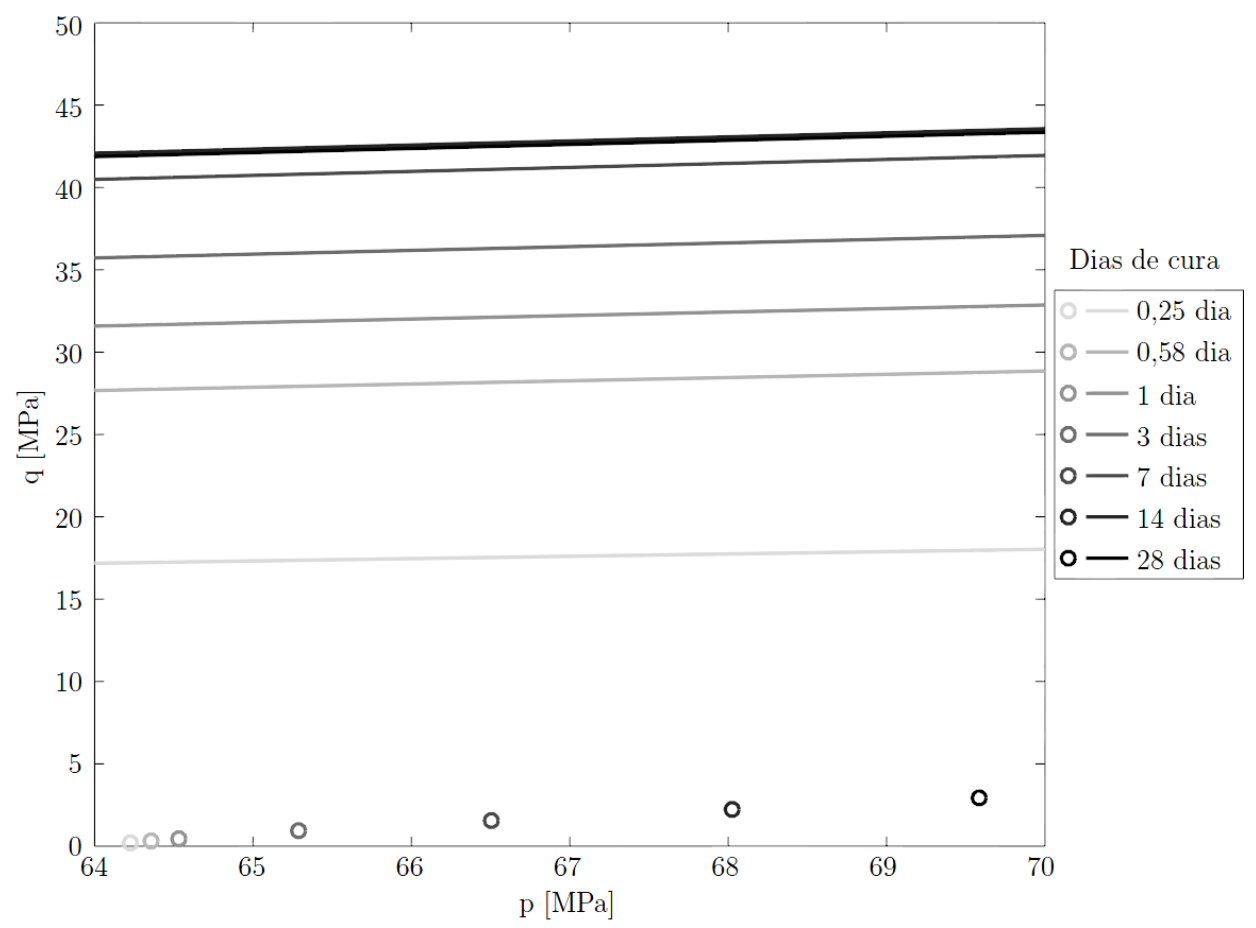

b)

Figura 4.18 - a) Estado de tensão e envoltória de ruptura para a pasta de cimento em diferentes idades b) zoom in

Mostra-se que a pasta de cimento se encontra em regime elástico durante o período considerado. Entende-se que o estado inicial de tensões hidrostático da pasta se revela fulcral para que não exista plastificação. Neste trabalho, apenas o efeito da deformação do sal por fluência altera o estado de tensão da pasta de cimento. Ao querer deformar por fluência, o sal fustiga o cimento radialmente fazendo com que as tensões desviadoras aumentem. Contudo, existem efeitos não contabilizados no presente trabalho, como a retração volumétrica da pasta por autodessecação (já anteriormente discutido), fluência volumétrica e fluência cisalhante (consultar Bernard et al. (2003) e Grasley \& Lange (2007)).

A inclusão destes efeitos pode alterar o campo de tensões volumétricas e cisalhantes ao longo do tempo. Figura 4.18 mostra que uma diminuição de tensão numa das direções principais de cerca de $25 \%$ nas primeiras 6 horas leva a pasta de cimento à plastificação. Cabe ressalvar que esta condição corresponde a $\sigma_{1}<\sigma_{2}=\sigma_{3}$, ou seja, o meridiano de tração. Como visto anteriormente, o D-P1 sobrestima a tensão de escoamento neste meridiano. Contudo, o ângulo de atrito no presente caso é baixo pelo que a inclusão do critério M-C não tem impacto relevante na análise.

Neste cenário, em que no processo de solidificação não se consideram os fenômenos de fluência e retração, a pasta de cimento exibe um estado de tensão com tensões cisalhantes muito distantes da envoltória de ruptura. Assim, os vários 
modelos constitutivos apresentados na seção 3.3.3 que contabilizam o dano da estrutura revelam-se desnecessários a esta análise.

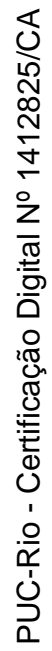




\section{5 \\ Conclusões e sugestões}

São apresentadas neste capítulo as conclusões finais e sugestões para posteriores trabalhos com o propósito de ajudar no desenvolvimento científico do tema estudado e fornecer ideias que possam servir de base para futuras pesquisas.

\section{1.}

\section{Conclusões}

Este trabalho apresenta uma metodologia para simulação das etapas de construção de poços. O modelo desenvolvido incorpora a fase de perfuração, reconstrução do revestimento metálico, bombeamento da pasta de cimento, retração autógena e a evolução das propriedades mecânicas até os 28 dias. Especial enfoque foi dado à última fase - a evolução das propriedades mecânicas do cimento. Os valores de deformação e de tensão nesta fase são realistas quando comparados com análises que não consideram o aumento das propriedades do cimento. Também se conseguiu automatizar o processo de modelagem desde a geração da malha de elementos finitos até a extração e avaliação de resultados no período de vida do poço considerado.

Pfeifle et al. (2001) não estaria errado ao afirmar que para prever com precisão as deformações do poço, as propriedades físicas do material cimento deveriam ser alteradas ao longo do tempo. Contudo, a inclusão destes efeitos na modelagem mostrou-se insignificantes quando compradas com as dimensões reais do poço. Rocha (2015) mostra a evolução do modulo de elasticidade da pasta do cimento no período de cura para temperatura ambiente $\left(20^{\circ} \mathrm{C}\right)$ e para temperatura in situ $\left(60^{\circ} \mathrm{C}\right)$. Ao incluir no modelo numérico os módulos de elasticidade aferidos no tempo para pastas de cimento curadas a $60^{\circ} \mathrm{C}$, constata-se que tanto as deformações como as tensões são similares à modelagem que excluí o efeito da evolução das propriedades da pasta.

Ao admitir uma tensão inicial hidrostática e desconsiderando efeitos como a fluência ou a retração da pasta de cimento durante a hidratação, chega-se à 
conclusão que a parcela desviatória (originada pela fluência do sal) é muito inferior quando comparada à parcela hidrostática. Assim, tendo em conta estas considerações simplificativas e neste caso de estudo, a inclusão de critérios plásticos se revelou supérflua.

Cooke et al. $(1983,1984)$ reportam um decréscimo de tensão ao longo do tempo na pasta de cimento. Porém, o estudo foi conduzido em um poço perfurado numa formação rochosa que não apresenta efeitos de fluência relevantes. Martins et al. (1997) também apresentaram um estudo no qual a pressão hidrostática no anular é medida em laboratório e não contabilizam a deformação do sal na pressão do anular. Nesta dissertação, chega-se à conclusão que existe um acréscimo de pressão anular devido ao movimento de sal. Ao deformar por fluência, o sal pressiona a pasta de cimento no anular. Quanto mais rígida a pasta, maior restrição aos deslocamentos impostos pelo sal e consequentemente maiores as tensões na pasta. Contudo, é importante referir que o estudo não avaliou a retração nem a fluência da pasta neste período.

Macay (2011) e Macay \& Fontoura (2014) tinham chegado também a um incremento de tensão no anular durante a evolução das propriedades da pasta de cimento. Contudo, durante a evolução das propriedades mecânicas, os autores apresentam incrementos significativos de tensões tangenciais e radiais. Ao analisar as tensões tangenciais iniciais e finais na fase de solidificação da pasta, conclui-se que as tensões aumentam entre 4 a 5 vezes de magnitude. No processo de solidificação, Macay (2011) também apresenta a dimensão do anular e verifica um aumento de dimensão do mesmo ao invés de uma diminuição. A modelagem desenvolvida nesta dissertação foi capaz de representar de forma correta o estado de tensões na pasta de cimento e as deformações do anular nessa etapa. Compararam-se modelagens que contemplam a evolução dos módulos de Young no tempo com modelagens que não contabilizam a evolução do módulo de elasticidade. Os resultados de deformação e tensão foram comparados entre essas análises e revelaram-se coerentes e de acordo com a física do problema. Esta dissertação mostra que para contabilizar o modulo de elasticidade ao longo do tempo, o estado de tensão não deve ser alterado de acordo com o incremento das propriedades mecânicas.

Poços que atravessam camadas de Halita são objeto dessa pesquisa. Como a análise do poço se debruçou sobre efeitos a curto prazo, procurou-se utilizar um 
modelo constitutivo para o sal que simule a fluência primária e secundária. Recorreu-se a uma lei que combina a lei de Duplo Mecanismo, que simula a fluência secundária, com parâmetros da lei de Potência, que simula a fluência primária. Esta lei Híbrida revelou-se de fácil implementação e poucos dados de entrada são necessários quando comparada com o modelo de Multi Mecanismo. Os resultados obtidos concordam com os resultados experimentais de Costa et al. (2005) e com aqueles de outros modelos constitutivos de fluência mais sofisticados como o de Multi Mecanismo. A lei Híbrida foi comparada com a lei de Multi e Duplo Mecanismo para poços. Chega-se à conclusão que a curto prazo a lei implementada resulta em valores de fechamento do poço superiores às outras leis.

O processo de perfuração revelou-se fulcral para o estado de tensão do poço. Inicialmente existe uma deformação elástica inicial que equilibra as tensões in situ da formação com a força aplicada na parede do poço que simula o peso da lama de perfuração. Este processo gera tensões desviatórias na parede do poço que agravam a deformação da parede do poço por fluência.

O processo de bombeamento do cimento alterou o campo de deslocamentos do anular. Porém, ao comparar a dimensão final do anular com a inicial neste passo, mostra-se que a inclusão deste não traz um ganho significativo à modelagem. Foi considerado que a retração, perda de fluídos da pasta e desenvolvimento de forças cisalhantes de contato entre a pasta e as superfícies do anular fazem com que a pressão hidrostática na pasta de cimento tome valores idênticos aos do fluído de perfuração. Esta simulação desconsiderou a retração após a pasta de cimento exibir uma rigidez associada, o que é uma premissa válida para meios impermeáveis. A fluência da pasta de cimento foi desconsiderada.

A metodologia que evita a sobreposição de malhas após a deformação do poço (apelidada neste trabalho de cement decoy) revelou-se simples e com resultados satisfatórios. 


\section{2. \\ Sugestões}

O presente trabalho considerou os efeitos a curto prazo, isto é, considerou as ações e fenômenos que precedem a produção do poço. Nenhum efeito a longo prazo foi tomado em conta nesta modelagem. Para trabalhos futuros, as considerações a longo prazo podem ser analisadas e estudadas, como a mudança de temperatura $\mathrm{e}$ pressão da fase de construção para a fase de produção.

Também se admitiu que as propriedades da pasta de cimento não sofreram alteração com a cimentação frente ao sal. Contudo, sabe-se que a inclusão desta variável pode alterar as propriedades da matriz cimentícia alterando os resultados.

Apenas a rocha halita foi considerada na simulação, mas existem outras rochas salinas com deformação por fluência mais acentuada, como por exemplo a carnalita. Assim, dependendo da tipologia salina, a fluência pode ser mais proeminente em outras condições de campo.

Vários autores mostram que a perda de integridade do poço perde-se com a fissuração da pasta ou perda de ligação entre revestimento/pasta ou pasta/formação rochosa. Neste trabalho, adotou-se uma ligação perfeita entre a pasta e os outros constituintes e admitiu-se um comportamento elástico e elastoplástico para o cimento. Embora vários autores tenham chegado a padrões de fissuração para a pasta de cimento, a literatura não oferece informações sobre os padrões de fissuração da pasta em poços perfurados em rocha salina. Como estudo futuro, seria interessante observar se devido à mudança de solicitações da fase de construção para a fase de produção a fluência do sal agrava este efeito na pasta.

Foram apresentadas as tensões na pasta de cimento. No período considerado, as tensões na bainha de cimento apresentaram uma pequena parcela desviatória quando comparada com a parcela hidrostática. Porém, a retração e a fluência da pasta de cimento podem atenuar o efeito hidrostático e culminar em tensões cisalhantes que levem à plastificação da pasta. Em futuros trabalhos, estes efeitos devem ser considerados. 


\section{Referências bibliográficas}

ABAQUS. Theory Manual. In: SIMULA Abaqus Documentation - Version 6.11. [S.1.]: [s.n.].

ABBAS, G. et al. Exprimental Study of Gas Migration Prevention Through Cement Slurry using Hydroxyproplylemthycellulose. IADC/SPE. Bangkok, Thailand: Asia Pacific Drilling Technology. 2014. p. 8.

AL-AJMI, A. M.; ZIMMERMAN, R. W. Stability analysis of vertical boreholes using Mogi-Coulomb failure criterion. International Journal of Rock Mechanics and Mining Sciences, 2006. 1200-1211.

BAZANT, Z. P. Thermodynamics of Solidifying or Melting Viscoelastic Material. Jornal of the Engineering Mechanics Division, p. 933-952, 1979.

BERGER, A. et al. Effect of Eccentricity, Voids, Cement Channels, and Pore Pressure Decline on Collapse Resistance of Casing. SPE Annual Technical Conference. Houston, Texas: Society of Petroleum Engineers. 2004. p. 8.

BERNARD, O.; ULM, F.-J.; GERMAINE, J. T. Volume and deviator creep of calcium-leached cement-based materials. Cement and Concrete Research, p. 1127-1136, 2003.

BOSMA, M. et al. Design Approach to Sealant Selection for the Life of the Well. SPE Annual Technical Conference. Houston, Texas: Society of Petroleum Engineers. 1999. p. 14.

BOURGOYNE, A. T.; SCOTT, S. L.; MANOWSKI, W. A reviw of sustained casing pressure occurring on the ocs. DOWELL-SCHLUMBERGER. [S.1.], p. 62. 2000.

CHENEVERT, M. E.; JIN, L. Model for Predicting Wellbore Pressures in Cement Columns. SPE. San Antonio, Texas: SPE - Society of Petroleum Engineers. 1989. p. 13. 
COOKE, C. E.; KLUCK, M. P.; MEDRANO, R. Field Measurements of Annular Pressure and Temperature During Primary Cementing. Jornal Of Petroleum Technology, 9 August 1983. 1429-1438.

COOKE, C. E.; KLUCK, M. P.; MEDRANO, R. Annular Pressure and Temperature Measurements Diagnose Cementing Operation. Jornal of Petroleum Technology, 20 May 1984. 2181-2186.

COSTA, Á. Aplicação de Métodos Computacionais e Princípios de Mecânica das Rochas no Projeto e Análise de Escavações Destinadas à Mineração Subterrânea. Tese de Doutorado. Rio de Janeiro. 1984.

COSTA, A. M. et al. Triaxial Creep Tests in Salt applied in Drilling Through Thick Salt Layers in Campos Basin - Brazil. IADC/IADC. Amestardam: Society of Petroleum Engineers. 2005. p. 9.

COSTA, A. M. et al. Geomechanics applied to well design through salt layers in Brazil: A History of success. ARMA. Salt Lake City, UT : American Rock Mechanics Association. 2010. p. 14.

DE SIMONE, M.; BRANDÃO, N. B.; ROEHL, D. Modelagem Numérica de Poços de Petróleo em Zona de Sal com Avaliação de Efeito Térmicos de Fluência. CILAMCE. Rio de Janeiro: CILAMCE. 2015. p. 12.

DUSSEAULT, M. B.; GRAY, M. N.; NAWROCKI, P. A. Why Oilwells Leak: Cement Behavior and Long-Term consequences. SPE International Oil and Gas Conference. Beijing: Society of Petroleum Engineers. 2000. p. 8.

EIERLE, B.; SCHIKORA, K. Computational Viscoelasticity of Aging Materials. European Conference on Computational Mechanics. Munchen, Germany: Technische Universität München. 1999. p. 15.

EIKAS, I. K. Influence of Casing Shoe Depth on Sustained Casing Pressure. Norwegian University of Science and Technology. Master of Science Thesis, p. 84. 2012.

FIRME, P. A. L. P. Modelagem Constitutiva e Análise Probabilística Aplicadas a Poços em Zonas de Sal. Dissertação de Mestrado. Rio de Janeiro. 2013. 
FIRME, P. A. L. P. et al. Creep constitutive modeling applied to the stability of pre-salt wellbores through salt layers. ARMA. Minneapolis, MN: American Rock Mechanics Association. 2014. p. 10.

FOSSUM, A. F.; FREDCRICH, J. T. Probabilistic analysis of borehole closure for through-sal well design. Acta Geotechnica, 2007. 41-51.

FUENKAJORN, K. Borehole closure in salt. University of Arizona. PhD Disseration. 1988.

GRASLEY, Z. C.; LANGE, D. A. The viscoelastic response of cement paste to three-dimensional loading. Mech Time-Depend Mater, p. 27-46, 2007.

GRAY, K. E.; PODNOS, E.; BECKER, E. Finite Element Studies of NearWellbore Region During Cementing Operations: Part I. SPE Production and Operations Symposium. Oklahoma City: Society of Petroleum Engnieers. 2007. p. 15.

HAMMER, T. A. Test Methods for Linear Measurements of Autogeneous Shrinkage Before Setting. In: TAZAWA, E.-I. Autogeneous Shrinkage of Concrete. London: E \& FN Spon, 1999. p. 143-154.

HEATHMAN, J.; BECK, F. E. Finite Element Analysis Couples Casing and Cement Designs for HT/HP Wells in East Texas. IADC/SPE International. Miami, Florida, USA: Drilling Conference. 2006. p. 23.

HENDERSON, D.; HAINSWORTH, D. Elgin G4 Gas Release: What Happened and the Lessons to Prevent Recurrence. SPE International. Long Beach, California: Society of Petroleum Engineers. 2014. p. 13.

HOLT, E. E. Early age autogenous shrinkage of concrete. VTT. Espoo, p. 197. 2001.

HUNTER, B.; TAHMOURPOUR, F.; FAUL, R. Cementing Casing Strings across Salt Zones: An Overview of Global Best Practices. SPE international. Jakarta, Indonesia: Society of Petroleum Engineers. 2009. p. 12.

JAMES, S.; BOUKHELIFA, L. Zonal Isolation Modeling and Measurements Past Myths and Today's Realities. SPE International. Abu Dhabi: Society of Petroleum Engineers. 2006. p. 9. 
JANDHYALA, S. et al. Cement Sheath Integrity in Fast Creeping Salts: Effects of Well Operations. SPE International. Aberdeen: Society of Petroleum Engineers. 2013. p. 10.

JIANG, H.; XIE, Y. A note on the Mohr-Coulomb and Drucker-Prager stength criteria. Mechanics Research Communications, 2011. 309-314.

LI, Z. et al. Theory-Based Review of Limitations With Static Gel Strength in Cement/Matrix Characterization. SPE Drilling \& Completion, 2016. 14.

MACKAY, E. Análise Geomecânica na Perfuração e Cimentação de Poços de Petróleo em Zonas de Sal. Pontifícia Universidade Católica do Rio de Janeiro. Rio de Janeiro. 2011.

MACKAY, F.; FOnTOURA, S. A. B. The Description of a Process for Numerical Simulations in the Casing Cementing of Petroleum Salt Wells Part I: from drilling to cementing. 48th US Rock Mechanics / Geomechanics Symposium. Minneapolis: American Rock Mechanics Association. 2014. p. 9.

MARTINS, A. L. et al. Tools for Predicting and Avoiding Gas Migration After Casing Cementing in Brazilian Fields. Rio de Janeiro, Brazil. 1997.

MEHTA, P. K.; MONTEIRO, P. J. M. Concrete - Microstucture, Properties, and Materials. Berkeley, California: McGraw-Hill, 2006.

MICHAUS, M.; NELSON, E.; VIDICK, B. Cement Chemistry and Additives. Oilfield Review, p. 18-25, 1989.

NBR5732: 1991 Cimento Portland comum - Especificação.

NEVILLE, A. M.; BROOKS, J. J. Concrete Technology. Harlow, England: Pearson Education Limited, 2010.

NP EN 197-1:2001 - Cimento - Parte 1: Composição, especificação e critérios de conformidade para cimentos correntes.

OLIVEIRA, B. F.; CREUS, G. J. An analytical-numerical framework for the study of ageing in fibre reinforced polymer composites. Composite Structures, 2004. 443-457. 
PFEIFLE, T. W. et al. An Investigation of the Integrity of Cemented Casing Seals with Application to Salt Cavern Sealing and Abandonment. Alburquerque, New Mexico. 2001.

PHILIPPACOPOULOS, A. J.; BERNDT, M. L. Mechanical Property Issues fo Geothermal Well Cements. Geothermal Resources Council Transctions, 2001. 119-124.

POIATE JR., E. Mecânica das Rochas e Mecânica Computacional ara Projetos de Poços de Petróleo em Zonas de Sal. Tese de Doutorado. Rio de Janeiro. 2012. POIATE, E.; COSTA, A. M.; FALCÃO, J. L. Well Design for Drilling Trhough Thick Evaporite Layers in Santos Bazin-Brazil. IADC/SPE international. Miami, Florida, USA: IADC/SPE international. 2006. p. 16.

RAVI, K. et al. Procedures to Optimize Cement Systems for Specific Well Conditions. Drilling Fluids Technincal. Houston, Texas, USA: American Associaton of Drilling Engineers. 2006. p. 11.

RAVI, K.; BOSMA, M. Improve the Economics of Oil and Gas Wells by Reducing the Risk of Cementing Failure. CIPM. Veracruz, México: CIPM. 2005. p. 10.

RAVI, K.; BOSMA, M.; GASTEBLED, O. Improve the Economics of Oil and Gas Wells by Reducing the Risk of Cement Failure. SPE international e IADC. Dallas, Texas: Society of Petroleum Engineers. 2002. p. 13.

ROCHA, C. A. A. Influência da pressão e temperatura de cura e da adição de NaCl e KCl no comportamento de pastas para a cimentação de poços de petóleo. Tese de Doutorado. Rio de Janeiro. 2015.

RODRIGUEZ, W. J.; FLECKENSTEIN, W. W.; EUSTES, A. W. Simulation of Collapse Loads on Cemented Casing Using Finite Element Analysis. SPE Annual Technical Conference. Denver, Colorado, USA: Society of Petroleum Engineers. 2003. p. 9.

SCHREPPERS, G. A framework for wellbore cement integity analysis. ARMA. San Francisco, CA, USA: American Rock Mechanics Association. 2015. p. 9. 
SHADRAVAN, A. et al. HPHT Cement Sheath Integrity Evaluation Method for Unconventional Wells. SPE international. Long Beach, California, USA: Society of Petroleum Engineers. 2014. p. 9.

SHADRAVAN, A.; AMANI, M. HPHT 101 - What Every Engineer or Geoscientist Should Know about High ressure High Tempreature Wells. SPE. Kuwait City, Kuwait: Society of Petroleum Engineers. 2012. p. 27.

SHAHRI, M. A.; SCHUBERT, J. J.; AMANI, M. Detectind and Modeling Cement Failure in High-Pressure/High-Temperature (HP/HT) Wells, Using Finite Element Method (FEM). International Petroleum Technology Conference. Doha: International Petroleum Technology Conference. 2005. p. 10.

SHAHRI, M. A.; SCHUBERT, J. J.; AMANI, M. Detecting and Modeling Cement Failure in High-Pressure/High-Temperature (HP/HT) Wells, Unsing Finite Element Method (FEM). IPTC. Doha, Qatar: International Petoleum Technology. 2005. p. 10.

SIMS, J. R.; KRAHL, N. W.; VICTORY JR., S. P. Triaxial Tests of Mortar and Neat Cement Cylinders. International Association for Bridge and Structural Engineering, 1966. 481-495.

THIERCELIN, M. J. et al. Cement Design Based on Cement Mechanical Response. SPE Drilling \& Completion, p. 266-273, December 1998.

WILLSON, S. M.; FOSSUM, A. F.; FREDRICH, J. T. Assessment of Salt Loding on Well Casing. IADC/SPE Drilling Conference. Albuquerque, NM, USA: IADC/SPE Drilling Conference. 2002. p. 10.

XU, R.; WOJTANOWICZ, A. K. Diagnosis of Sustained Casing Pressure from Bleed-off/Buildup Testing Patterns. SPE international. Oklahoma City, Oklahoma, USA: Society of Petroleum Engineers. 2001. p. 15. 